\title{
THE
}

\section{RICE INSTITUTE}

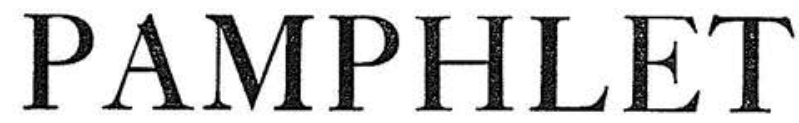

\section{Vol. XXXVIII July, $1951 \quad$ No. 2 MONOGRAPH IN ENGLISH}

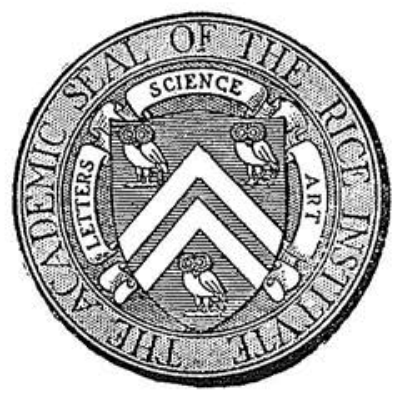

Published by

THE RICE INSTITUTE

A university of liberal and technical learning founded by William Marsh Rice in the City of Houston, Texas, and dedicated by him to the advancement of Letters, Science, and Art 

THE RICE INSTITUTE PAMPHLET Vol. XXXVIII July, $1951 \quad$ No. 2

THE BACKGROUND OF THOMSON'S

LIBERTY

$B y$

Alan Dugald McKmLop 



\section{CONTENTS}

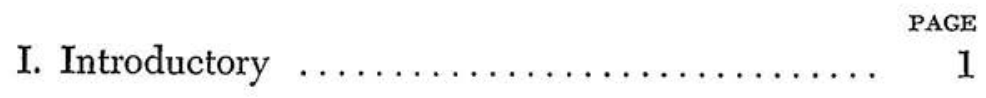

II. The Setting for the Grand Tour $\ldots \ldots \ldots \ldots \ldots 12$

III. The View of Italy $\ldots \ldots \ldots \ldots \ldots \ldots \ldots \ldots$

IV. Ancient History $\ldots \ldots \ldots \ldots \ldots \ldots \ldots \ldots \ldots, 41$

V. The Fine Arts $\ldots \ldots \ldots \ldots \ldots \ldots \ldots \ldots \ldots$

VI. Northern Liberty $\ldots \ldots \ldots \ldots \ldots \ldots \ldots \ldots \ldots$

VII. Political Intentions $\ldots \ldots \ldots \ldots \ldots \ldots \ldots \ldots$

Notes $\ldots \ldots \ldots \ldots \ldots \ldots \ldots \ldots \ldots \ldots \ldots$

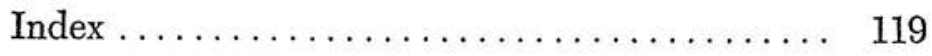





\section{INTRODUCTORY}

7 HE MAJOR events in James Thomson's literary career, 1 if we overlook his dramas, were the completion of the first version of The Seasons (1726-30), the writing of Liberty (1735-36), the extensive final revision of The Seasons (1738-46), and the appearance "after fourteen or fifteen years" of The Castle of Indolence (1748). Liberty has generally been regarded as a total failure, and has rightly been passed over in favor of The Seasons and The Castle of Indolence. Yet in Liberty we have the result of Thomson's second period of sustained writing. So much work by a man of his distinction deserves reëxamination, even though it must be admitted that his natural bent and his best talents were here overcome by ideas and patterns imposed on him by the age. It is not the purpose of the present study to rehearse the early external and textual history of the poemthat has been done elsewhere ${ }^{1}$-but rather to offer some account of the ideas and patterns. ${ }^{2}$

The personal and biographical setting may be given briefly. It was customary to send a young Englishman of the upper classes abroad in the company of a tutor, who often turned out to be a needy and industrious Scot. ${ }^{3}$ With the aid of the Reverend Thomas Rundle, James Thomson had been thus engaged as tutor to Charles Richard Talbot, the eldest son of the eminent Charles Talbot, at that time Solicitor General and soon to become Lord Chancellor. Early in November 1730 the two travelers went to Paris. By the end of November 1731 they were in Rome, when Thomson wrote to Dodington: "We have been over the most part of France and Italy." ${ }^{*}$ Details of their itinerary are lacking, but apparently they had gone by way of Lyons 
and Avignon into northern Italy and had already visited Venice. A letter of Rundle's dated merely "Ashdown-Park, Friday morning, 1731," says that Thomson is there, ${ }^{5}$ and if the date is right implies a hurried return to England before the end of the year. This is somewhat hard to imagine, but at any rate a letter sent by Thomson to Lady Hertford from Paris, October 10, 1732, shows that his tour was somehow extended to that time. ${ }^{6}$ This letter is closely related to Part I of Liberty, and may indicate that he had begun writing the poem. The publication of the five parts extended from January 1735 to February 1736, with an interval of nine months between Parts III and IV.

The general title Liberty was given to the following series: I-"Antient and Modern Italy Compared," II-"Greece," III-"Rome," IV-“Britain," V-“The Prospect." A contemporary reader could tell at once that what he was going to get would be a "progress of liberty." But a progress poem was often a varied sequence or survey. The plan would admit of the mingling of history, generalization, and description, almost at the poet's will. The descriptive-didactic blank verse poem did not have to stick closely to a theme. One could imagine a work that would be more or less both The Seasons and Liberty. Thus the description of a virtuoso named Maynard in a minor novel of the next generation shows how the two might go together:

His language is simple, but his sentiments are sublime; and while his arguments convince the understanding, his example influences the conduct. A professed admirer of antiquity, he dwells with rapture on the sculpture, the paintings, the manners of the ancients; and, more from judgment than false delicacy, points out and condemns the contrast. He contemplates with delight the wonders of the creation, and is charmed with nature, even in her most unpleasing forms. ${ }^{7}$

We can best realize the nature of the plan which underlies 
Liberty by considering how the project connects with The Seasons. It is possible to think of The Seasons as the progress of the enthusiastic poet, animated by benevolism and natural piety, through the cycle of the year to a fuller knowledge of God as manifested in nature. Liberty is a parallel progress through history. Both poems end with a "prospect," as at the conclusion of Winter:

The great eternal scheme, Involving all, and in a perfect whole Uniting, as the prospect wider spreads, To reason's eye refin'd clears up apace.

(Ll. 765-68.)

The Hymn at the end of The Seasons closes with the conception of "infinite progression" in the manifestations of divine goodness. The conception of the progress of Liberty is likewise optimistic; the ideal must in the long run prevail, and the poem is usually accused of being excessively complacent. But at a given time the ideal is withdrawn or withheld from mortal man, as when during the Dark Ages Liberty takes flight to Heaven and is veiled from human sight (III, 545-71). And the final "Prospect" closes thus:

As thick to View these varied Wonders rose, Shook all my Soul with Transport, unassur'd, The Vision broke; And, on my waking Eye, Rush'd the still Ruins of dejected Rome.

$(\mathrm{V}, 717-20$.

The world of external nature gives fuller play to Thomson's optimism than the world of history. A benevolent and relatively carefree view of the world, which allows the poet to evade or postpone the problem of evil, releases and encourages Thomson's remarkable power of generalizing description in The Seasons. The role of philosophic virtuoso and commentator is important; it is the incentive for the 
whole work, and we could not expect to get the pictures without the framework and the ground-plan. Liberty, starting from much the same point of origin, is hampered by a ready-made interpretation of history which does not encourage free improvisation and variety of treatment. The problem of evil leads in The Seasons to descriptive variety and contrast, in Liberty to somewhat stereotyped polemic. The result amounts to artistic failure, but also affords valuable illustrations of the course of popular thought in the Age of Walpole.

The optimistic view of history here takes the form of panegyric or hero-worship based on a benevolist theory of ethics. This central idea is well stated in an early letter from Thomson to Aaron Hill:

The Excellent ones of the Earth, in the Exercise of Social Love, feel it as much to be an original Impulse, as the low World that blind Affection, they bear themselves; nor are they, in the least, conscious of that forc'd, cold Reasoning, by which it is deduc'd from so mean an Original.

How many deathless Heroes, Patriots, and Martyrs, have been so gloriously concern'd for the Good of Mankind, and so strongly actuated by Social Love, as frequently to act in direct Contradiction to that of Self?

A great many more Arguments might be adduced to prove, that Social Love is a nobler, independent Principle, by itself, were not the secret Sense, that every good Man has of the Matter, instead of a thousand. ${ }^{8}$

In the earliest texts of Winter, such sentiments underlie the catalogue of ancient worthies of whom he reads in Plutarch ("the long-liv'd Volume")-Socrates, Solon, Lycurgus, Numa, Cimon, Aristides, Timoleon, Cato, Scipio, Pelopidas, and Epaminondas-

Sages of antient time, as gods rever'd, As gods beneficent, who blest mankind With arts, and arms, and humaniz'd a world.

(Winter, 11. 422-24.) 


\section{Introductory}

The deeds of these heroes are connected with providentially controlled cycles of history:

Historic truth

Should next conduct us thro' the deeps of time:

Point us how empire grew, revolv'd, and fell,

In scatter'd states; what makes the nations smile,

Improves their soil, and gives them double suns;

And why they pine beneath the brightest skies,

In nature's richest lap. As thus we talk'd,

Our hearts would burn within us, would inhale

That portion of divinity, that ray

Of purest heaven, which lights the glorious flame

Of patriots, and of heroes. (Winter, 1l. 489-99.)

An anonymous poem, The Loss of Liberty: or Fall of Rome (1729), sometimes attributed to James Ralph, imitates Thomson's blank-verse style, greatly extends his catalogue of Roman heroes, and associates the glories of ancient Rome with the cult of ruins and the decline of liberty through moral corruption. Thomson was to move in this direction, but up to 1730 his mood is predominantly, though not exclusively, enthusiastic and eulogistic. In line with classical hero-worship are the memorial poem on Newton in 1727, based on Lucretius' praise of Epicurus, and the catalogue of British worthies in Summer-Bacon, More, Barrow, Tillotson, Locke, Boyle, Newton, Shakespeare, and Milton in the first edition (1727); More (compared to Cato, Aristides, and Cincinnatus), Walsingham, Drake, Raleigh, Hampden, Sir Philip Sidney, Sir Algernon Sidney ("the British Brutus," in the final text "the British Cassius"), Lord Russell, Bacon ("Plato, the Stagyrite, and Tully join'd"), Shaftesbury, Boyle, Locke, Newton, Shakespeare, and Milton in the revision of 1730. In both texts the catalogue is connected with praise of British prosperity and political ideals:

Happy Britannia! where the Queen of arts,

Inspiring vigour, Liberty abroad 
Walks thro' the land of Heroes, unconfin'd And scatters plenty with unsparing hand.

(Summer, 11. 534-37.)

By 1730 we can thus note a growing interest in English political history, along with a turn to classical republicanism and Whig liberalism.

Specific political allusions become more frequent in 1730 , both in Autumn and in the revised text of Winter. The dedication of Autumn to Speaker Onslow seeks "to mix the patriot's with the poet's flame" (1. 22). The patriotic note is struck in the lines in praise of the movement to revive Scottish industries and fisheries (11. 846-64) and the accompanying eulogies of Forbes of Culloden and the Duke of Argyle. The passage on "philosophic Melancholy" characteristically combines the love of nature with public and private virtue:

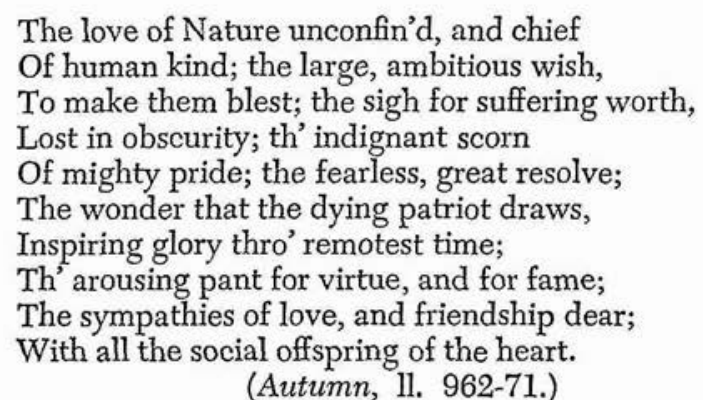

The tribute to the Jail Committee added to Winter in 1730 shows the theme of patriotism translated into an attack on current abuses and thus shading into political controversy. ${ }^{9}$ But Thomson had already made the transition from "pointing with pride" to "viewing with alarm" in Britannia (January, 1729), a short occasional poem hailing the arrival of Prince Frederick in England, praising the Royal Family, attacking the peace policy of Walpole, and, what is important 
for us to note, setting forth the opposition between liberty and luxury which is a central theme for Liberty itself. ${ }^{10}$ Instead of being exuberantly praised as in Summer, Britain is described as

A state, alone, where Liberty should live, In these late times, this evening of mankind, When Athens, Rome, and Carthage are no more, The world almost in slavish sloth dissolv'd.

(Ll. 195-98.)

The nation is warned at great length against the corrosive effects of luxury and corruption, though there is still hope for the British, Liberty's chosen people, under the stimulating effect of a northern climate and the fostering of public spirit by the Throne.

Thus the political-editorial vein shows the threat to liberty or the possible defeat of liberty. This is the theme of the influential dramas that deal with subjects from Roman history, Addison's Cato (1713) and Thomson's Sophonisba (1730). There may be a decline and fall of liberty, or a retreat and flight, a last stand. The situation may be translated into terms of setting and environment. Liberty and republicanism go with a life of austerity or privation amid simple or harsh surroundings; imperialism and luxury go with a lavish natural setting as well as with high culture and self-indulgence. Thomson's reference to Cato in Africa follows this tradition:

Yet here, even here, into these black abodes

Of monsters, unappall'd, from stooping Rome,

And haughty Caesar, Liberty retir'd,

With Cato leading thro' Numidian wilds:

Disdainful of Campania's fertile plains,

And all the green delights of Italy;

When for them she must bend the servile knee, And fawning take the blessings once her own.

(Summer, 11. 790-97.) 
In Addison's Cato the early austerity and the progressive imperialism are set in parallel. Thus the pro-Roman African prince Juba says:

A Roman soul is bent on higher views:

To civilize the rude, unpolished world,

And lay it under the restraint of laws;

To make man mild and sociable to man;

To cultivate the wild, licentious savage

With wisdom, discipline, and lib'ral arts-

Th' embellishments of life; virtues like these

Make human nature shine, reform the soul,

And break our fierce barbarians into men.

(I, iv.)

But Cato himself is the Plutarchan hero incarnating selfsufficient virtue in a corrupt world.

There may'st thou see to what a godlike height

The Roman virtues lift up mortal man.

And when his fortune sets before him all

The pomps and pleasures that his soul can wish,

His rigid virtue will accept of none.

(I, iv.)

Sometimes he is made to express British constitutional ideas in Roman terms:

Remember, $\mathrm{O}$ my friends, the laws, the rights,

The generous plan of power delivered down,

From age to age, by your renowned forefathers,

(So dearly bought, the price of so much blood)

$\mathrm{Oh}$, let it never perish in your hands!

But piously transmit it to your children.

Do thou, great Liberty, inspire our souls,

And make our lives in thy possession happy,

Or our deaths glorious in thy just defense.

$$
\text { (III, v.) }
$$

In Thomson's Sophonisba, Rome likewise plays a double role. For the heroine herself, a female Cato, the cause of liberty is identified with opposition to Roman conquest. 


\section{Introductory}

Hope lives not here,

Fled with her sister Liberty beyond

The Garamantian hills, to some steep wild,

Some undiscover'd country, where the foot

Of Roman cannot come. (I, iii.)

But for the conquering Scipio and the pro-Roman Masinissa, the extension of Roman power is virtuous and beneficent:

From savage nature,

'Tis patience that has built up human life,

The nurse of arts! and Rome exalts her head

An everlasting monument of patience.

( $V$, ii.)

In the concluding lines of the play the opposition is reconciled:

She had a Roman soul; for every one

Who loves, like her, his country is a Roman.

Whether on Afric's sandy plains he glows,

Or lives untam'd among Riphaean snows,

If parent-liberty the breast inflame,

The gloomy Libyan then deserves that name:

And, warm with freedom, under frozen skies,

In farthest Britain Romans yet may rise.

$(\mathrm{V}, \mathrm{ix}$.

This generalization of Roman virtue leaves unresolved the conflict between early republicanism and later imperialism and the broader opposition of primitivism and progress.

But Thomson was adopting literary forms rather than wrestling with ideas, and he may have thought of the transition from The Seasons to Liberty as comparable to the transition from the Eclogues and the Georgics to the epic poem. Departing from chronological order for a moment, we may note the conception of a transition from free reverie to heroic poetry, as expressed in The Castle of Indolence:

Come on, my Muse, nor stoop to low Despair, Thou Imp of Jove, touch'd by celestial Fire!

Thou yet shalt sing of War, and Actions fair, 
Which the bold Sons of Britain will inspire;

Of antient Bards thou yet shalt sweep the Lyre;

Thou yet shalt tread in Tragic Pall the Stage,

Paint Love's enchanting Woes, the Heroe's Ire,

The Sage's Calm, the Patriot's noble Rage,

Dashing Corruption down through every worthless Age.

(I, xxxii.)

Though in the autumn of 1730 Thomson was discussing plans for an epic with Dodington, ${ }^{11}$ the main point is that the ideal of heroic poetry could be extended to other than epic performances. Samuel Boyse's lines "To Mr. Thomson, upon his Tragedy of Sophonisba," published in April 1730, indicate the pattern pretty well.

When Nature first inspir'd thy early Strain, To paint the Beauties of the Flow'ry Plain, The charming Page I read with soft Delight, And every lively Landskip charm'd my Sight;

Now led by thee, while I again explore,

New Patriots rising on a barbarous Shore;

A beauteous Breast that glows with Love of Fame,

A Female Cato, with a softer Name!

My ravish'd Heart exults in being free,

And burns with Love of sacred Liberty!

Let Rome the blessing arrogate no more;

The Goddess reigns upon a distant Shore;

And there in all her native Charms confest,

She fires immortal Sophonisba's Breast;

Great Carthage rises from Oblivion's Womb,

By thee reviv'd, she quits her awful Tomb;

And emulates again her haughty Rival Rome.

So when great Titian rose, immortal Man!

With rural Scenes his Pencil first began,

Employ'd all-genial Nature's Laws to trace,

And copy from her ever-blooming Face;

Here paint the Precipice and falling Flood,

There strike the Vale,-or mark the distant Wood;

Till rising in his Skill by just Degrees,

He form'd th' Idea of th' Historic-Piece;

Where some great Hero boldly he design'd,

And touch'd th' exalted Passions of the Mind:

Of Art with Nature, such the generous Strife,

That all the speaking Canvas swell'd with Life! ${ }^{12}$ 


\section{Introductory}

The historical and political theme might in expectation and theory earn for Liberty a place above The Seasons, just as epic and drama were ranked above descriptive poetry, and historical painting above landscape painting.

But, as Britannia indicated as early as 1729 , the theme of liberty was translated into current terms; a political-historical code modified the free and easy digressive method which Thomson had followed in The Seasons. Such a code was more or less inevitable for him, but in particular it came through his studies and experiences in connection with the Grand Tour, and was reënforced by his personal and political connections in the decade of the 1730 's. The general intention of Liberty may thus be described as "Whig panegyric," to employ the term given currency by Courthope and extended in a learned article by Cecil A. Moore. ${ }^{13}$ One might say in this case, perhaps, "dissident Whig panegyric." The description is acceptable if the political or patriotic intention is viewed in the round, in its full context. As Dobrée has recently noted, the patriotic theme in Augustan verse turns up in various places and in various forms, such as "Liberty, Trade, Historical Sense or View of the Future, Peace, Public Works, Justice, or Pride in Literary Achievement." ${ }^{14} \mathrm{~A}$ full account of Thomson's poem must then reckon both with these large themes and with specific political intentions. 


\section{THE SETTING FOR THE GRAND TOUR}

$\mathrm{A}^{\mathrm{N}}$ INTELLIGENT young man starting on the Grand A Tour would know in advance what he was going to see in France and Italy and what as a patriotic Briton he ought to think of what he saw. Behind the program lay a cosmopolitan ideal of culture, an underlying purpose which could give meaning to the detailed and disjointed descriptions in the travel books. Shaftesbury, whose influence can be made out even more clearly in Liberty than in The Seasons, wished to wean the Englishman from his crude local attachments and his autochthonous barbarism. Arts and civil accomplishments "came to us by degrees, from remote distances, at second or third hand; from other Courts, States, Academys, and foreign Nurserys of Wit and Manners." The Englishman should emulate the cosmopolitan Athenian, and should be free to take the best that the ancients and the polite moderns have to teach him. The basic attitude is "original Native Liberty," that is, the free realization of innate standards of beauty, truth, and goodness. ${ }^{2}$ The general connection of this concept with politics is stated thus:

You, Philocles, who are such an Admirer of Civil Liberty, and can represent it to yourself with a thousand several Graces and Advantages; can you imagine no Grace or Beauty in that original Native Liberty, which sets us free from so many inborn Tyrannys, gives us the Privilege of ourselves, and makes us our own, and Independent? A sort of Property, which, methinks, is as material to us to the full, as that which secures us our Lands, or Revenues.

I shou'd think, said he ... that one might draw the Picture of this Moral Dame to as much advantage as that of her Political Sister; whom you admire, as describ'd to us "in her Amazon-Dress, with a free manly Air becoming her; her Guards the Laws, with their written Tables, like Bucklers, surrounding her; Riches, Traffick, and Plenty, with the Cornu- 
copia, serving as her Attendants; and in her Train the Arts and Sciences, like Children, playing."

The liberty for which he pleads is of course liberty under law-moral aesthetic, political. "I can no more allow that to be Free-living, where unlimited Passion, and unexamin'd Fancy govern, than I can allow that to be a Free Government where the mere People govern, and not the Laws. . . . Reason and Virtue alone can bestow Liberty."

From this broad conception we pass without a break to the familiar idea that the arts flourish in a free state and decline under tyranny. The Longinian Treatise on the Sublime mentions as "trite" the idea that literary genius rises and falls with freedom, and that prosperity and luxury corrupt both civic character and artistic power. This conception was a part of the traditional rhetorical theory. Thus Wotton uses the dialogue De Causis Corruptae Eloquentiae attributed to Tacitus or Quintilian:

There were no more Demosthenes's or Tully's, after the Macedonian and Roman Emperors had taken away the Liberty of the Graecian and Roman Commonwealths. It is Liberty alone which inspires Men with Lofty Thoughts, and elevates their Souls to a higher Pitch than Rules of Art can direct. Books of Rhetoric may make Men Copious and Methodical; but they alone can never infuse that true Enthusiastic Rage which Liberty breathes into their Souls who enjoy it. ${ }^{5}$

Shaftesbury too dwells on the connection between the rise of the persuasive arts and the development of the fine arts among free peoples. ${ }^{6} \mathrm{He}$ has hopes of new triumphs for Great Britain now that liberty has been fully realized by the Revolution of 1688 :

We are now in an Age when Liberty is once again in its Ascendant. And we are ourselves the happy Nation, who not only enjoy it at home, but by our Greatness and Power give Life and Vigour to it abroad; and are the Head and Chief of the European League, founded on this Common Cause. ... 'Tis with us at present, as with the Roman People in those 


\section{Background of Thomson's Liberty}

early Days, when they wanted only repose from Arms to apply themselves to the Improvement of Arts and Studys. ${ }^{7}$

This, we may say, is the flush of Whig enthusiasm after the Revolution, colored by the Williamite policy of steadfast military opposition to France.

But when it comes to the actual achievements of national cultures, ancient and modern, certain difficulties arise. Shaftesbury has to credit the great works of Roman literature to the Republic, to argue that the great Augustans gathered the last fruits of liberty. ${ }^{8}$ And what of enslaved France and free England? When we speak of the Augustan Age in England, we should consider what difficulties the term might give. Was not the Age of Louis XIV more Augustan than anything Britain could show? As far as Shaftesbury applies his conception of liberty under law to literature, it is clear that France is a better example than England.

'Tis evident, our natural Genius shines above that airy neighbouring Nation; of whom, however, it must be confess'd, that with truer Pains and Industry, they have sought Politeness, and study'd to give the Muses their due Body and Proportion, as well as the Natural Ornaments of Correctness, Chastity, and Grace of Stile. ${ }^{9}$

If liberty is the nurse of polite letters in France, it is evidently not what the British patriot means when he speaks of liberty. The conflict appears in some familiar lines at the end of Pope's Essay on Criticism:

The rules a nation, born to serve, obeys;

And Boileau still in right of Horace sways.

But we, brave Britons, foreign laws despis'd,

And kept unconquer'd, and unciviliz'd;

Fierce for the liberties of wit, and bold,

We still defy'd the Romans, as of old.

Yet some there were, among the sounder few

Of those who less presum'd, and better knew,

Who durst assert the juster ancient cause,

And here restor'd Wit's fundamental laws.

(Ll. 713-22.) 
Authority in politics and authority in the arts thus pull in different directions. The man of taste could not always be so anti-Gallican as Whig liberalism might require.

Yet, as we might expect, national prejudices had their way. A British moralist might interpret the triumph of the fine arts on the Continent in terms of tyranny and luxury. He might even associate it with his dislike of the Restoration, when foreign influences were felt to be at their height. This is what Pope does in the Epistle to Augustus:

In Days of Ease, when now the weary Sword

Was sheath'd, and Luxury with Charles restor'd;

In ev'ry taste of foreign Courts improv'd,

"All, by the King's Example, liv'd and lov'd."

The Soldier breath'd the Gallantries of France,

And ev'ry flow'ry Courtier writ Romance.

Then Marble, soften'd into life, grew warm,

And yielding Metal flow'd to human form:

Lely on animated Canvas stole

The sleepy Eye, that spoke the melting soul.

No wonder then, when all was Love and sport,

The willing Muses were debauch'd at Court:

On each enervate string they taught the note

To pant, or tremble thro' an Eunuch's throat.

(Ll. 139-42, 145-54.)

And when the English observer took into account not only aristocratic culture but the general state of the nation, he might end by finding more horrible examples than magnificent achievements on the Grand Tour. Shaftesbury, despite his devotion to Whig doctrine, is kept by his emphasis on an ideal of universal culture from siding with England against the Continent or emphasizing ancient British virtue, but after 1700 this position is exceptional. Rough equivalents were set up in a highly simplified version of history: the ideal of civic virtue for Great Britain is republican Rome; contemporary France represents the luxurious life and the moral and social corruption of the 
Empire-the immediate consequences of tyranny; contemporary Italy represents the prostration and ruin that ensue upon the decline of imperial power-the ultimate consequences of tyranny.

In actual reports of the Grand Tour these political generalities are of course combined with continuing enthusiasm for virtù. The classical tradition alone would still make Italy an enchanted land. Addison's verse Letter from Italy (1703), admired by countless readers from Pope to Goldsmith and obviously a strong influence on Liberty, expresses in a pleasing though conventional way the view of the Grand Tour taken over by the eighteenth century. Here we find enthusiasm for classical associations and for the delights of Italian landscape and climate, along with more perfunctory references to the grandeur of ruins, to ancient sculpture, and to Italian art. But the political motif enters also: oppression and tyranny make all these glories of little avail. Addison adapts for the glorification of Britain two famous passages in Virgil, the praise of Italy in Georgic II and the lines on the manifest destiny of Rome in Aeneid VI. Let others luxuriate in a semi-tropical climate, and excel in the arts; it is Britain's destiny to realize the ideals of Liberty at home and abroad.

'Tis Liberty that crowns Britannia's Isle,

And makes her barren rocks and her bleak mountains smile.

It is appropriate that this couplet of Addison's should stand on the titlepage of the edition of Liberty published at Glasgow in 1774.

This simply sketched position connects easily with the doctrine of the balance of interests in an ideal mixed government which Addison takes from Polybius and applies to the British constitution (Spectator, No. 287, January 29, 
1712), and with the elaborate allegory of Liberty which he gives us in the Tatler, No. 161, April 20, 1710. This performance, to our way of thinking, is filled with tasteless symbolism and iconography, but it is an important and influential example of "Whig panegyric." Amid the Alps, mountains traditionally associated with the hardy liberty of the Swiss, the spectator finds a prospect of transcendent beauty:

I was wonderfully astonished at the Discovery of such a Paradise amidst the Wildness of those cold, hoary Landskips which lay about it; but found at length, that this happy Region was inhabited by the Goddess of Liberty; whose Presence softened the Rigours of the Climate, enriched the Barrenness of the Soil, and more than supply'd the Absence of the Sun.

Here flowers grow in natural luxuriance, and a river winds through the landscape. The irregular, the varied, and the spontaneous belong in Liberty's domain. But the political symbolism dominates:

This River, after having made its Progress through those free Nations, stagnates in a huge Lake at the leaving of them, and no sooner enters into the Regions of Slavery, but runs through them with an incredible Rapidity, and takes its shortest Way to the Sea.

In this Alpine paradise sits enthroned the Goddess of Liberty, with the Genius of a Commonwealth on one hand and the Genius of Monarchy on the other. The former wears a liberty cap and holds a wand "like that with which a Roman Citizen used to give his Slaves their Freedom"; she is daring and cruel, even "mean and vulgar" in her air, with her mantle marked with the symbols of assassination and inscribed, "the Ides of March." The vision reflects fear of mob rule and tyrannicide. In Liberty's train "were the several Arts and Sciences, who all of them flourished under- 
neath her Eye." And what is often taken to be the most characteristic theme of Whig panegyric is emphasized in the vision of "two other dependent Goddesses, who made a very conspicuous Figure in this blissful Region," Plenty and Commerce, the first with plough and cornucopia, the second with "rostral Crown" and compass. The armies that besiege this mountain fastness are led by Tyranny and Licentiousness.

The Revolution settlement, the course of British military and diplomatic history, and the economic progress of the country sharpened the polemic against continental tyranny. Henry St. John himself, the future Lord Bolingbroke, who can hardly be accused of being a commercial-minded Whig, writes from the Continent in 1698 about the scourge of absolute government, the glories of Roman law and the ancient Roman zeal "for liberty, courage, integrity and virtue," and the insidious policy of Charles II in undermining liberty by luxury. ${ }^{10}$ Native English polity and genius should conform to the lofty standards of Greece and Rome rather than to contemporary European culture. In the Prologue to John Dennis's Iphigenia (1700) "the Genius of England rises to a Warlike Symphony."

$\mathrm{Oh}$ is my Brittain faln to that degree, As for effeminate Arts t' abandon me? I left th' enslav'd Italian with disdain, And servile Gallia, and dejected Spain: Grew proud to be confin'd to Brittain's shore, Where Godlike Liberty had fix'd before; Where Liberty thrives most, I most can soar. Once more I thought $t$ ' inspire Athenian flights, And once more towr to Sophoclean heights.

This gives us the context of Addison's Cato, the opposition between ancient tragedy and modern opera, and the connection of a progress of liberty with the national rivalries 
of contemporary Europe. A simple statement in a play by Mrs. Centlivre in 1714 would have been accepted by any patriotic Englishman:

The English are by nature, what the Ancient Romans were by discipline-courageous, bold, hardy, and in love with liberty. Liberty is the idol of the British, under whose banner all the nation lists; give but the word for liberty, and straight more armed legions wou'd appear, than France and Philip keep in constant pay. ${ }^{11}$

The orientation continued to be toward Greece and Rome, France and Italy. But the patriotic Englishman considering issues raised by the Grand Tour would not proceed very far in his political theory without reckoning with the idea of the "Gothic" or northern origin of the liberties of modern Europe. The setting for Thomson's use of this important idea will be discussed later; here it need only be noted that the doctrine of northern liberty brought together a simplified version of mediaeval history, an inclination toward primitivistic ideas, and a strongly nationalistic theme which had already carried much weight in political discussion. It enabled the enthusiast for liberty to get clear for a time of the cultural complications of France and Italy. Viscount Molesworth's Account of Denmark (1694), aggressively Whig and classically republican, describes what he conceives to be the loss of constitutional liberty in one of its last northern strongholds. The principal reason for an Englishman's traveling at all, he says in his long Preface, is that he may see with his own eyes the consequences of the loss of liberty. "The more polish'd and delicious Countries of France, Spain, or Italy, are not the places where this observation may be made to greatest advantage. . . . But in the Northern Kingdoms and Provinces, there appears little or nothing to divert the Mind from contemplating 
Slavery in its own colours without any of its Ornaments." ${ }^{12}$

As we come to Thomson's generation we find his future friend and patron Lyttelton moved in France by what he calls "the spirit of Whiggism," while he predicts that "it will still encrease when I come into Italy, where the oppression is more sensible in its effects, and where the finest country in the world is quite depopulated by it." ${ }^{13}$ And his verse epistle to his Oxford tutor Dr. Ayscough sums up the ideology of the Grand Tour. He imagines his friend reading the historians who tell of the fall of Greece and Rome; he expresses mixed feelings about France, the glories of her literature, the grandeur of her public works, the mingled pride, servility, and folly of her ruling classes; he thinks with renewed enthusiasm of British freedom, but looks with apprehension on the enslaved states of the Continent. ${ }^{14}$ In his Epistle to Pope, written from Italy, he echoes Addison, and urges the poet to sing of English liberty-

Sing the land which yet alone can boast

That Liberty corrupted Rome has lost. ${ }^{15}$

Thus cultural interest and political hostility might be combined in various proportions in the Briton's account of the Grand Tour. To judge from Thomson's letters, he moved from the vague enthusiasm of the young traveler to an increasingly severe moral and political didacticism. Two weeks before starting for the Continent, he wrote ardently to Dodington:

Travelling has been long my fondest wish, for the very purpose you recommend-the storing one's imagination with ideas of all-beautiful, all-great, and all-perfect Nature. These are the true materia poetica, the light and colours with which Fancy kindles up her whole creation, paints a sentiment, and even embodies an abstracted thought. I long to see the fields whence Virgil gathered his immortal honey, and to tread the same ground where men have thought and acted so greatly! 


\section{The Setting for the Grand Tour}

If it does not give, it must at least awaken, somewhat of the same spirit.

At my times of leisure abroad I think of attempting another tragedy, and on a story more addressed to common passions than that of Sophonisba. People nowadays must have something like themselves, and a public-spirited monster can never concern them. ${ }^{16}$

He goes on to say that he hesitates to undertake an epic poem on the subject of Timoleon, a Plutarchan theme which had evidently been suggested to him by Dodington; an author, he continues, "owes the scene of an epic action to his own country," and must nowadays avoid pagan machinery. He adds, "Should the scenes and climates through which I pass inspire me with any poetry, it will naturally have recourse to you." Evidently he still entertains a preference for descriptive poetry of a markedly idealistic and enthusiastic kind, in spite of urgings toward the "historic piece," or heroic poem.

At the end of the year he wrote Dodington from Paris:

There are scarce any travellers to be met with, who have given a landscape of the countries through which they have travelled; that have seen (as you express it) with the Muse's eye; though that is the first thing that strikes me, and what all readers and travellers in the first place demand. It seems to me, that such a poetical landscape of countries, mixed with moral observations on their governments and people, would not be an ill-judged undertaking. But then, the description of the different face of Nature, in different countries, must be particularly marked and characteristic, the Portrait-painting of Nature. ${ }^{17}$

In this plan poetical description of foreign landscapes, such as we actually find in the later version of The Seasons, would still seem to predominate; the "moral observations on their governments and people" might be thought of as somewhat similar in scale and tone to the political passages that had already appeared in the 1730 texts of Winter and 
Autumn. But political ideas were becoming more insistent. In the same letter Thomson comments on Voltaire's Brutus: "It is matter of amusement to me to imagine what ideas an old Roman Republican, declaiming on Liberty, must give the generality of a French audience." And he concludes:

Amidst all that external and shewy magnificence which the French affect, one misses that solid magnificence of trade and sincere plenty which not only appears to be, but is, substantially, in a kingdom where industry and liberty support and inspirit each other. . . . I shall return no worse Englishman than I came away.

The word "Englishman" applied to himself by a young Scot is worth noting here. His pupil shared his sentiments. Thomas Rundle wrote on January 30, 1731, concerning Charles Richard Talbot at Paris: "His rough English love for liberty, disdains the embroidered slavery, that glitters in that trifling Court." ${ }^{\prime 18}$

By November 28, 1731, when Thomson again writes to Dodington from Rome, he confesses that he is fed up with the Grand Tour and the cultivation of virtù:

That enthusiasm I had upon me with regard to travelling goes off, I find, very fast. One may imagine fine things in reading of ancient authors, but to travel is to dissipate that vision. A great many beautiful, antique statues, where several of the fair ideas of Greece are fixed for ever in marble, and the paintings of the first masters are indeed most enchanting objects. How little however of these suffices? How unessential are they to life? And surely not of that importance as to set the whole world, man, woman, and child a-gadding. I should be sorry to be Goth enough not to think them highly ornamental in life, when one can have them at home without paying for them an extravagant price; but for every one who can support it to make a trade of running abroad only to stare at them, I cannot help thinking something worse than a public folly. Instead of travelling so furiously, it were a wiser and more public-spirited thing, with part of those vast sums of money spent that way, to send people of genius for architec- 


\section{The Setting for the Grand Tour}

ture, painting and sculpture, to study these arts here and to import them into England. Did they but once take root there, how they might flourish, in such a generous and wealthy country! The great architect, painter, and statuary, Nature, is the same she ever was, and no doubt as profuse of beauty, proportion, lovely forms and real genius as formerly to the sunny realms of Greece, did we but study the one and exert the other. In England though, if we cannot reach the gracefully superfluous, yet I hope we will never lose the substantial, necessary and vital arts of life, such as depend on liberty, labour and all-commanding trade. For my part I, who have no taste in the least for smelling to an old musty stone, look upon these other curiosities with an eye to poetry, in regard that the sister arts reflect lights and images on one another. Now that I mention poetry, should you enquire after my muse, all that I can answer is that I believe she did not cross the Channel with me. I know not whether your gardener at Eastbury has heard anything of her among the woods there. She has not thought fit to visit me while in this once poetic land, nor do I feel the least presages that she will. ${ }^{19}$

These somewhat depressing sentiments hardly support Johnson's conjectural account of Thomson's state of mind during his travels:

He was yet young enough to receive new impressions, to have his opinions rectified, and his views enlarged; nor can he be supposed to have wanted that curiosity which is inseparable from an active and comprehensive mind. He may therefore now be supposed to have revelled in all the joys of intellectual luxury; he was every day feasted with instructive novelties. ${ }^{20}$

We may even ask with Thomson's biographer, G. C. Macaulay, when he quotes this letter, why under these circumstances the poet undertook to write Liberty at all. ${ }^{21}$ But in spite of his Philistine views about the place of the fine arts in the national economy, we can detect a vague intention to use painting and sculpture as materials for a descriptive poem.

Thomson's letter to Lady Hertford from Paris, October 


\section{Background of Thomson's Liberty}

10, 1732, discovered by Miss Hughes among the Percy papers at Alnwick, brings us much closer to Liberty. Speaking of his correspondence with Lady Hertford, the poet abandons "a vain imagination of writing in the character of a traveller," and asks to be absolved "from any rash promises I made while the fairy prospect lay before me." We may interpret what follows to mean that in any poem on his travels description will be restricted by the ideology of the Grand Tour:

There are certainly several very fine natural Scenes to be seen abroad, but they are saddened by the misery of their Inhabitants, and Scenes of human misery ought never to please but in a tragedy. The bad Government in Italy, and perticularly that of the Priests, has not only extirpated almost [all?] human arts and Industry but even disfigured Nature her self. Tho they might command all that can tend either to the convenience, pleasure, or magnificence of life, yet are they in some sort destitute of all. The gracious sun indeed still dispences to them his powerfull smiles, but him they are afraid of. It ought to be considered rather as the land of the dead than of the living. Suppose one who is perfectly master of the antient Poets and Historians suddenly transported there, without knowing what country it was; he would scarce I fancy find it out by their descriptions. After, 'tis true, having wandered through a vast desolate plain, where by degrees began to appear the tombs of Heroes, broken arches, and aqueducts, till at last thro' many majestic ruins he came to the palatine mount, the seat of the Imperial palace: here, would he say, astonished at the awful prospect, here must have stood Rome the mistress of the World-Behold an Empire dead! and these venerable ruins all around, these triumphal arches, pillars, remains of temples, Baths aqueducts and Amphitheatres are her wide spread monument a monument, tho' made up of ruins, infinitely, infinitely more noble than all the other monuments of the world put together. Several peices of Grecian sculpture that may be said to adorn this monument are divine. was I writing to another than your Ladyship I might forget my self, and say, that they represent a finer nature than is to be found now-a-days. The famous Italian painters having taken their Ideas from them, no wonder that their works should be so vastly Superior to the paintings of all other Nations, as they 


\section{The Setting for the Grand Tour}

beyond comparison are. The language and musick in Italy are Inchanting. being but an Infant in the language I ought not to pretend to judge of it, yet cannot I help thinking it not only very harmonious, and expressive but even not at all incapable of manly Graces. as for their Music it is a sort of charming malady that quite disolves them in Softness, and greatly heightens in them that Universal Indolence men naturally (I had almost said reasonably) fall into when they can receive little or no advantage from their Industry. ${ }^{22}$

The parallels between Liberty and this remarkable letter, which need not be set forth in detail, are markedly and exclusively with Part I, and suggest that Thomson began by concentrating on the idea of a "ruins of Rome" poem. It is even possible that Part I had already been written as an independent poem about on the scale of Britannia. $\mathrm{He}$ would thus combine the descriptive projects hinted at previously with the political ideas brought out by the Grand Tour. Formerly he had drifted into the writing of The Seasons by starting from a relatively short Winter; perhaps the project of Liberty followed the same course, though it was probably more deliberate and mechanical, or came to be so. "Antient and Modern Italy" implies in a general way the rest of the poem, but it may appropriately be studied by itself as the earliest part of the poem to be written, and as the most obvious connecting link with Thomson's travels. 


\section{THE VIEW OF ITALY}

THE TRAVELER cannot get free of his guidebook. 1 This is true even of a sturdy and mature writer like Smollett, and it clearly applies to the sensitive and docile Thomson. In connection with the Grand Tour he studied French and Italian, read history, and drew on travel books and on manuals of antiquities and the fine arts. The later additions to The Seasons, also inspired in large part by books, could under favorable circumstances be fused with a core of direct observation and sentiment; but Liberty lacked from the first what Johnson found wanting in the revision of The Seasons-"what Temple calls their race, ... the flavour of the soil." As a traveler in Italy, Thomson would be likely to see what the books told him he was going to see. In particular, he depended on the account given in Addison's Remarks on Several Parts of Italy (1705, 2nd edition 1718), at the same time, as has been suggested above, extending the ideas found in Addison's accompanying verse Letter from Italy. Addison himself refers in his Preface to other writers of travel books:

We are obliged to the Bishop of Salisbury, for his masterly and uncommon Observations on the Religion and Governments of Italy: Lassels may be useful in giving us the Names of such Writers as have treated of the several States through which he pass'd: Mr. Ray is to be valu'd for his Observations on the Natural Productions of the Place. Monsieur Misson has wrote a more correct Account of Italy in general than any before him, as he particularly Excels in the Plan of the Country, which he has given us in true and lively Colours. ${ }^{1}$

Of these works the Travels $(1686,1687)$ of Gilbert Burnet, Bishop of Salisbury, proves to be of importance for Thomson. And we can be virtually certain that the other books in 
Addison's short list were known to him-Richard Lassels' Voyage of Italy (1670), John Ray's Observations made of the Low Countries, Germany, etc., (1673), and Misson's New Voyage to Italy (translated into English 1695, 4th revised edition of translation 1714). Lassels, Ray, and Misson are all to be found, somewhat rewritten, in the second enormous folio volume of Harris's Navigantium atque Itinerantium Bibliotheca, usually called Harris's Travels (1705), a compilation known to Thomson and used by him. ${ }^{2}$ Addison of course cannot be set up as an exclusive source, but he was without doubt a general guide for the young poet, and his work will help us to see what is happening in Liberty I.

In "Antient and Modern Italy Compared" the theme is the contrast between the glories of ancient Rome, both republican and imperial, and the physical and moral degradation of modern Italy under the influence of tyranny. Thomson does not give us an elaborate picture of the grandeur of the ruins of antiquity, as John Dyer does afterwards in his excellent poem The Ruins of Rome (1740), yet in Part I the plan is more markedly descriptive than in the later parts. Moreover, the idealization of classical antiquity makes the view of Rome that we have here more like the vision of the imperial city in Paradise Regained, IV, 33-85, than like the Savior's condemnation of Roman luxury and tyranny in Milton's following lines, Paradise Regained, IV, 110-153. Thomson's theme at this point is not the fall of Rome but the abject state of modern Italy. The travelers helped him to make this drastic simplification in both literary and political terms.

Despite the political implications of his view of Italy, Addison is especially proud of being a literary traveler: 
I have taken care particularly to consider the several Passages of the Ancient Poets, which have any Relation to the Places or Curiosities that I met with: For before I entered on my Voyage I took care to refresh my Memory among the Classic Authors, and to make such Collections out of them as I might afterwards have Occasion for. I must confess it was not one of the least Entertainments that I met with in Travelling, to examine these several Descriptions, as it were, upon the Spot, and to compare the Natural Face of the Country with the Landskips that the Poets have given us of it. (Sig. al.)

Thomson's relation to Addison's Remarks appears in his use of the tissue of literary and geographical allusion thus put at his disposal. But along with Addison, it will be convenient to consider another travel manual, Edward Wright's Some Observations Made in Travelling through France, Italy, bc., (1730), dedicated to George, Lord Parker, with whom the author traveled as tutor. This work was in Thomson's library, and it is possible that he bought it soon after publication as part of his preparation for the Grand Tour. ${ }^{3}$ Wright sometimes dovetails with Addison as a source for details in Liberty I. Of course the travel books often gave similar descriptions and used the same references. Thomson's lines on oriental marbles in Roman buildings:

Asian Hills

Lend their best Stores to heave the pillar'd Dome

(I, 100-01.)

these rich Remains

Of Marbles now unknown, where shines imbib'd Each parent Ray-

(I, 236-38.)

can be annotated from Addison, who speaks of "that amazing variety of ancient Pillars of so many kinds of Marble," and "such kinds of Marble as are no where to be found but among Antiquities" (2nd edition, pp. 270, 271), but also from Wright: "their finest Works, where they employ such 
sorts of Marble as are not the Growth of Italy, and are scarce (if at all) now to be had, except in the Ruins of old Temples ... for the adorning of which, Aegypt and India were ransacked" (p. 201). The lines immediately following in Thomson-

\section{these massy Columns, hew'd}

From Africk's farthest Shore; one Granite all, These Obelisks high-towering to the Sky, Mysterious mark'd with dark Egyptian Lore (I, 238-41.)

are sufficiently accounted for by Addison's references to pillars wrought "entire and solid" of various materials and sent "ready shap'd" from Egypt and other countries to Rome, and by his remark on the undecipherable hieroglyphics on obelisks (pp. 271-72, 278), perhaps in conjunction with Misson, who tells us that the obelisks are all of granite. ${ }^{4}$

Detail accumulates until full commentary becomes oppressive, and general parallels or even possible sources sometimes become too numerous to control; but it may be worth while to see how Addison and Wright together help to account for the following remarkable passage, essential to Thomson's "ancient and modern" parallel:

Thy Tibur, Horace, could it now inspire,

Content, Poetic Ease, and Rural Joy,

Soon bursting into Song: while thro' the Groves

270

Of headlong Anio, dashing to the Vale,

In many a tortur'd Stream, you mus'd along?

Yon wild Retreat, where Superstition dreams,

Could, Tully, you your Tusculum believe?

And could you deem yon naked Hills, that form,

Fam'd in old Song, the Ship-forsaken Bay,

Your Formian Shore? Once the Delight of Earth,

Where Art and Nature, ever-smiling, join'd

On the gay Land to lavish all their Stores;

How chang'd, how vacant, Virgil, wide around,

Would now your Naples seem? Disaster'd less 
By black Vesuvius thundering o'er the Coast, His midnight Earthquakes, and his mining Fires, Than by Despotic Rage: that inward gnaws, A native Foe; a foreign, tears without. First from your flatter'd Caesars This began: Till, doom'd to Tyrants an eternal Prey, Thin-peopled spreads, at last, the Syren Plain, That the dire Soul of Hannibal disarm'd; And wrapt in Weeds the Shore of Venus lies. There Baia sees no more the joyous Throng; Her Banks all beaming with the Pride of Rome: No generous Vines now bask along the Hills, Where sport the Breezes of the Tyrrhene Main: With Baths and Temples mixt, no Villas rise; Nor, Art-sustain'd amid reluctant Waves, Draw the cool Murmurs of the breathing Deep:

No spreading Ports their sacred Arms extend:

No mighty Moles the big intrusive Storm, From the calm Station, roll resounding back.

An almost total Desolation sits,

A dreary Stillness, sad'ning o'er the Coast;

Where, when soft Suns and tepid Winters rose, Rejoicing Crouds inhal'd the Balm of Peace; Where city'd Hill to Hill reflected Blaze; And where, with Ceres, Bacchus wont to hold A genial Strife. Her youthful Form, robust, Even Nature yields; by Fire, and Earthquake rent: Whole stately Cities in the dark Abrupt Swallow'd at once, or vile in rubbish laid, A nest for Serpents; from the red Abyss New Hills, explosive, thrown; the Lucrine Lake A reedy Pool; and all to Cuma's Point, The Sea recovering his usurp'd Domain, And pour'd triumphant o'er the bury'd Dome. (I, 268-315.)

With 11. 268-72 we may associate the earlier lines:

To Anio's Roar, and Tibur's Olive Shade;

To where Preneste lifts her airy Brow;

Or downwards spreading to the sunny Shore,

Where Alba breathes the Freshness of the Main. (I, 63-66.)

For this group we have a chain of references in Addison: translating Silius Italicus, "the loud Anio's boist'rous 
Clamours" (p. 288); the "praeceps Anio" of Horace, followed by a paragraph on its broken and winding course (pp. 286-87); "Tivoli's delightful Shades," translating Horace's "Tiburni lacus" (p. 286). For Praeneste's "airy Brow" we have in Addison: "Palaestrina stands very high, like most other Towns in Italy, for the Advantage of the cool Breezes, for which Reason Virgil calls it Altum, and Horace, Frigidum Praeneste" (p. 289).

272-73. Thomson's note: "Tusculum is reckoned to have stood at a Place now called Grotta Ferrata, a Convent of Monks." Addison calls it "Grotto Ferrate," and does not mention the monks. But Montfaucon's Travels from Paris thro' Italy (1712) identifies Frascati with the ancient Tusculum, and locates there the monastery of Grotta Ferrata, which is described at length (pp. 390, 393).

275-77. Thomson's note: "The Bay of Mola (anciently Formiae) into which Homer brings Ulysses, and his Companions. Near Formiae Cicero had a Villa." Wright speaks of "Mola [anciently Formiae]" (p. 138), and following Misson and especially Cluverius, continues to give Thomson the wording of his note: "this Port, between Formiae and Cajete, was the Port certainly understood for that into which Homer brings Ulysses and his Companions." His reference to Cicero's villa at Formiae follows at p. 142.

277-81. Addison, on the neighborhood of Naples: "The Works of Art lye in no less Disorder than those of Nature, for that which was once the most Beautiful Spot of Italy ... has now nothing to show but the Ruins of its ancient Splendor" (pp. 167-68).

284-87. For the correlation of the ravages of despotism with natural catastrophe, see below, pp. 35-40. Both Addison and Burnet have much to say of tyranny in Naples.

288-89. Thomson's note: “Campagna felice, adjoining to 
Capua." Hannibal at Capua was a commonplace, and Thomson had already used the theme in Sophonisba, V, ii. "Syren plain" was suggested by the association of Naples with the Siren Parthenope, a familiar theme for which Addison has a chain of references (pp. 161-63).

290. Thomson's note: "The Coast of Baia; which was formerly adorned with the Works mentioned in the following Lines; and where amidst many magnificent Ruins, those of a Temple erected to Venus are still to be seen." The line and note connect with a quotation from Martial, "Litus beatae Veneris aureum Baias" (Wright, p. 183; Misson, 4th edition, I, 451). Addison (p. 195) and Wright (p. 173) also have Martial's "Haec Veneris sedes" for the neighborhood of Naples. Addison (p. 172) and Wright (pp. 177, 184) name the temple of Venus among ruins of other temples.

293-94. Cf. Wright, p. 177: "The Monte Gauro, once so famous for its Wines, afterwards became (thro' Earthquakes, \&c.) in a great measure barren." He goes on to say that it has been replanted; Addison (p. 167) and Thomson keep it barren. Thomson's line also connects with the description of Campania by Florus, quoted by Wright (p. 147) and translated, "Here are Mountains clothed with Vines," etc.

295-97. Addison (p. 169), but not Wright, gathers the references in Horace's Odes (II, xviii; III, i; III, xxiv) to villas at Baia built on foundations extending into the sea. No doubt Thomson read his Horace, but it seems likely that he got his references from Addison at this point instead of hunting them out for himself.

298-300. In the same passage Addison, like other travelers, describes the famous Mole of Puteoli or Mole of Baia, sometimes called "Caligula's Bridge"; but with this Thomson 
associated other quotations in Addison-lines in Virgil and Silius Italicus describing how the Mole of Baia repelled storms (Addison, pp. 211, 213), and the account of the port of Ostia with its "mighty Mole," to use the phrase in Dryden's translation of Juvenal which Addison cites (p. 228) and Thomson echoes. From this passage in Juvenal, Thomson also got his image of the arms of the port stretched out to embrace the sea (Porrectaque bracchia ... quae pelago occurrunt medio) in 1. 298.

303-04. Thomson's note: “All along this Coast, the antient Romans had their Winter Retreats; and several Populous Cities stood." With this, and the "soft Suns and tepid Winters" of 1. 304, cf. Addison: "Bajae was the Winter Retreat of the old Romans, that being the proper Season to enjoy the Bajani Soles, and the Mollis Lucrinus" (p. 173). 306-07. Lassels quotes a phrase from Lucius Florus' description of the Campania Felix, "Certamen Cereris et Bacchi," and translates, "the Strife of Ceres and Bacchus." In Wright we have "Liberi Cererisque Certamen," "where Ceres and Bacchus contend for victory" (p. 147). The whole passage from Florus as quoted by Wright influenced Thomson (see note to Il. 293-94 above).

307-08. Like 11. 281-83 above, influenced by Addison's description of the environs of Puteoli and Baia: "The Country about 'em, by reason of its vast Caverns and Subterraneous Fires, has been miserably torn in Pieces by Earthquakes, so that the whole Face of it is quite chang'd from what it was formerly" (p. 167).

311-12. Addison, loc. cit., says of the same neighborhood: "Several Fields ... a are now naked Plains, smoaking with Sulphur, or encumber'd with Hills that have been thrown up by Eruptions of Fire." But the reference is principally 
34 Background of Thomson's Liberty

to the famous eruption of 1538: "The Monte Novo was thrown out by an Eruption of Fire, that happen'd in the Place where now the Mountain stands" (Addison, p. 179). All the travelers refer to this catastrophe: a well known account is in George Sandys' Travels, and other accounts are in Misson and Montfaucon. ${ }^{6}$

312-13. Other accounts more clearly than Addison (p. 167) associate the filling up of the Lucrine Lake with the Monte Nuovo eruption. With Thomson's "reedy Pool" cf. Sandys: "This famous Lake is now no other than a little sedgy plash, choaked up by the horrible and astonishing eruption of the new Mountain" (p. 216). This seems a bit closer to Thomson than the other equivalents, "Pond" in Misson, "Puddle" in Addison, "fenny Meadow" in Ray.

314-15. Addison, loc cit., says of the submerged villas of Puteoli and Baia: "The Sea has overwhelm'd a Multitude of Palaces, which may be seen at the Bottom of the Water in a calm Day." But Thomson's "usurp'd Domain" is again closer to Sandys, where we read of Baia: "The extruded Sea hath again regained his usurped limits: made apparent by the paved Streets, and traces of foundations to be seen under water" (p. 228).

Liberty I is largely indebted for the application of its basic political thesis to Burnet's Travels (1686). Addison too is indebted to Burnet, and his influence works in the same direction; but Burnet hammers away more insistently on the correlation of prosperity with liberty and desolation with tyranny, and organizes his account about this central idea. Addison suggests in his Preface that political study is part of the program of the traveler in Italy: "No other Country in the World has such a Variety of Governments, that are so different in their Constitutions, and so refined in their 
Politicks." Thus the contrast between the effects of liberty and tyranny can be shown within the confines of Italy. A passage in Liberty IV shows Thomson applying this idea in a rapid survey of the free states of Italy as Liberty progresses northward from Rome to Britain. He comments thus on the small republics of the Arno plain:

The Republics of Florence, Pisa, Lucca, and Sienna. They formerly have had very cruel Wars together, but are now all peaceably subject to the Great Duke of Tuscany, except it be Lucca, which still maintains the Form of a Republic (IV, 269 n.)

Addison has a section in praise of the Republic of Lucca, to a remark in which Thomson is indebted:

This Republick is shut up in the Great Duke's Dominions, who at present is very much incensed against it, and seems to threaten it with the Fate of Florence, Pisa, and Sienna. (Pp. 309-10, misnumbered 109-10.)

When Thomson proceeds to Genoa, he represents Liberty as saying:

The barren Rocks themselves beneath My Foot, Relenting bloom'd on the Ligurian Shore.

Thick-swarming People there, like Emmets, seiz'd Among surrounding Cliffs, the scatter'd Spots, Which Nature left in her destroying Rage. (IV, 280-84.)

And he adds a note: "The Genoese Territory is reckoned very populous, but the Towns and Villages for the most part lie hid among the Apennine Rocks and Mountains." This is the general theme of the power of Liberty to create prosperity in barren mountainous regions. In the present passage it comes directly from Burnet:

In the Coast of Genoua, there is for many miles as it were a constant tract of Towns and Villages, and all those are well peopled, though they have scarce any Soil at all, lying under the Mountains that are very barren, and that expose them 
to a most uneasie Sun; and that they lie upon a boistrous Sea that is almost always in a storm, and that affords very few Fish: and yet the gentleness of the Government draws such multitudes thither, and those are so full of Wealth, that Money goes at Two per cent. ${ }^{8}$

Thomson continues:

There, in white Prospect, from the rocky Hill Gradual descending to the shelter'd Shore, By $\mathrm{Me}$ proud Genoa's marble Turrets rose. And while My genuine Spirit warm'd her Sons, Beneath her Dorias, not unworthy, She Vy'd for the Trident of the narrow Seas, E'er Britain yet had open'd all the Main. (IV, 286-92.)

This probably owes its substance to Lassels' Voyage of Italy. Genoa, he says, is commonly called la Superba. "It stands upon the side of a hill, and rising by degrees, appears to those that look upon it from the Sea, like an Amphitheater." Thomson's "rocky Hill" corresponds to Lassels" "great Hills of Marble" behind the town, and the "shelter'd Shore" corresponds to Lassels' description of the great mole which protects the harbor of Genoa. Lassels frequently refers to marble palaces in the Strada Nuova and other parts of the city. Thomson's political comment in the last four lines quoted may seem very general, but we may compare Lassels here too, describing the Fountain of Neptune in the Doria Palace: "In the midst of it stands the rare Fountain of Neptune, representing the true looks of brave Andria D'Oria the Neptune of the Ligurian Sea, and the man who put his Country out of Livery, and taught it not to serve."10 Lassels' account of Genoa is highly enthusiastic, and emphasizes wealth and military power, not decline. His praise of the city is adapted by Thomson to the theme of liberty and combined with Burnet's view of the Ligurian coast. Reënforcing details in Addison, though known to Thomson, need not be quoted here. 
The passage on Venice which closes the sequence on Italian republics does not reflect the high esteem for the Venetian polity found in earlier liberal theorists, who ranked that state with Rome and Sparta. ${ }^{11}$ Thomson of course knows the tradition, and is, as often, moved by the idea of the retreat of Liberty. Venice was originally the spot where, in the words of the Goddess,

push'd from plunder'd Earth, a Remnant still Inspir'd by $\mathrm{Me}$, thro' the dark Ages kept Of My old Roman Flame some Sparks alive.

(IV, 294-96.)

Thomson's note explains: "Those who fled to some Marshes in the Adriatic Gulph, from the Desolation spread over Italy by an Irruption of the Huns, first founded there this famous City, about the Beginning of the Fifth Century." This seems to be from John Ray's Observations: "The first Origin of Venice must be traced as far as the Irruption of the Huns into Italy, under Attila, when many of the best Families of Italy fled for shelter into these Islands, and at last erected here a noble City." ${ }^{12}$ Thomson's adjacent note on IV, 293 runs: "Venice was the most flourishing City in Europe, with regard to Trade, before the Passage to the East-Indies by the Cape of Good Hope, and America, were discovered." Elementary as this is, it can also be traced to Ray: "This City, according to its Epithet, Venice the Rich, did once surpass in Wealth, all the other Cities of Europe, and not without Reason, till the Passage to the East-Indies by the Cape of Good Hope was discovered."13 Thomson's glorification of Venice as "the seeming God-built City" echoes the well known Latin epigram of Sannazaro, adapting the speech of Neptune to Jupiter: "Compare Rome and Venice, and you will say that one is of man, the other founded by the gods." ${ }^{14}$ In speaking of the present state of Venice, 
however, Thomson reflects the hostile attitude toward the jealous and tyrannical Venetian oligarchy which is found in Addison, following Amelot de la Houssaye. ${ }^{15}$

Thomson's republican sequence continues with praise of the mountain freedom of Switzerland. Geneva is a model of political and religious liberty, and the natural virtue and local attachment of the Swiss are associated with an Alpine paradise.

Even, chear'd by Me, their shaggy Mountains charm,

More than or Gallic or Italian Plains;

And sickening Fancy oft, when absent long,

Pines to behold their Alpine Views again:

The hollow-winding Stream: the Vale, fair-spread

Amid an Amphitheatre of Hills;

Whence, vapour-wing'd, the sudden Tempest springs:

From Steep to Steep ascending, the gay Train

Of Fogs, thick-roll'd into romantic Shapes:

The flitting Cloud, against the Summit dash'd;

And, by the Sun illumin'd, pouring bright

A gemmy Shower; hung o'er amazing Rocks,

The Mountain-Ash, and solemn-sounding Pine:

The snow-fed Torrent, in white Mazes tost, Down to the clear Aetherial Lake below:

And, high o'er-topping all the broken Scene, The Mountain fading into Sky; where shines On Winter Winter shivering, and whose Top Licks from their cloudy Magazine the Snows. (IV, 344-62.)

This is one of the few successful landscapes in Liberty, and its connection with Thomson's interest in the primitive and the picturesque has been discussed elsewhere. ${ }^{16}$ It is part of the general plan for connecting politics and topography which had been passed on to the Whig commentators by Gilbert Burnet. Switzerland is the antitype to Italy. A writer of 1739, after quoting Molesworth on Denmark and Burnet on Switzerland and Italy, sums up by saying: "Thus we may see no Countries are so fine and plentiful by Nature, 
but they may be depopulated and ruined by Tyranny: hardly any so unpleasant and barren, but may be agreeable and eligible by Liberty." ${ }^{.17}$

The most elaborate landscape in Liberty I comes from Burnet, and may be put into a kind of double opposition, both to the natural beauties of the Alps and to the cultivated beauties of a free country like Britain, as described in Summer and at the opening of Liberty V.

Come! by whatever Sacred Name disguis'd, Oppression, come! and in thy works rejoice!

See Nature's richest Plains to putrid Fens Turn'd by thy Fury. From their chearful Bounds, See raz'd th' enliv'ning Village, Farm, and Seat.

First, Rural Toil, by thy rapacious hand Robb'd of his poor Reward, resign'd the Plow; And now he dares not turn the noxious Glebe. 'Tis Thine intire. The lonely Swain himself, Who loves at large along the grassy Downs His Flocks to pasture, thy drear Champian flies. Far as the sickening Eye can sweep around, 'Tis all one Desart, desolate, and gray, Graz'd by the sullen Bufalo alone; And where the rank uncultivated Growth Of rotting Ages taints the passing Gale. Beneath the baleful Blast the City pines, Or sinks infeebl'd, or infected burns. Beneath it mourns the solitary Road, Roll'd in rude Mazes o'er th' abandon'd Waste; While Antient Ways, ingulph'd, are seen no more.

(I, 123-43.)

Whatever personal impressions may be included in these lines, they are substantially derived from Burnet's account of the Papal States and his report of the coastal regions from Cività Vecchia to Naples. Between Monte Fiascone and Viterbo he found that "a vast Champion Country lay almost quite deserted."

When I was within a days Journey of Rome, I fancied that the Neighbourhood of so great a City must mend the matter: 


\section{Background of Thomson's Liberty}

but I was much disappointed, for a soil that was so Rich, and lay so sweetly, that it far exceeded any thing I ever saw out of Italy, had neither Inhabitants in it, nor Cattle upon it, to the tenth part of what it could bear: The surprize that this gave me, encreased upon me as I went out of Rome on its other side, chiefly all the way to Naples, and on the way to Civita-vecchia, for that vast and rich Champion Countrey that runs all along to Terracina . . . is abandoned to such a degree, that as far as ones eye can carry one, there is often not so much as a House to be seen; but on the Hills that are on the North side of this Valley, and by this dispeopling of the Country, the Air is now become so unwholesome, that it is not safe to be a night in it all the Summer long, for the Water that lies upon many places not being drained, it rots: and in the Summer this produces so many noisome steams, that it is felt even in Rome it self; and if it were not for the breeses that come from the Mountains, the Air would be intollerable. ${ }^{18}$

This makes one wonder whether some later lines (I, 173-85) in which Thomson refers in stilted style to the bad rooms in Italian inns and the idleness in Italian towns may not come from a passage a few pages later in Burnet, though one would assume that a traveler would find these things for himself. But the passage that immediately follows (I, 15072), describing the neglected state of a naturally rich mountain region, seems clearly to derive from Burnet's account of agricultural and industrial depression in the Kingdom of Naples. ${ }^{19}$ It is perhaps an understatement to say that Burnet was a forerunner of Addison; ${ }^{20}$ in political animus Burnet set the tone, and Addison, influential though he was, could not better the instruction. Furthermore this group of political and topographical ideas, as we may call them, handed on from Burnet to Thomson, colored Goldsmith's verse in the next generation, and can be found in the passages on Switzerland and Italy in The Traveller, and in the vision of depopulation and desolation in The Deserted Village. ${ }^{21}$ 


\section{ANCIENT HISTORY}

T T IS an evil day for the state, writes Thomson, when the 1 ideal of public virtue is "deem'd the declaiming Rant of Greece and Rome" (V, 326). On the contrary, a sincere patriot will look back longingly to the times when

Greece shone in Genius, Science, and in Arts, And Rome in Virtues dreadful to be told!

To live was Glory then! and charm'd Mankind, Thro' the deep Periods of devolving Time, Those, raptur'd, copy; These, astonish'd, read. (V, 272-76.)

The classical tradition imposed on the poet who would treat it on a large scale a tremendous task which only a Dante or a Milton might hope to accomplish. Thomson here falls a victim to the idea that the importance or sublimity of the subject somehow confers importance and sublimity on the verse. He could do better, we feel, with an oblique approach and a less pretentious program. Yet artistic failure does not make his intention negligible or historically unimportant. If these ideas did not come alive in Thomson's imagination, they still meant much to Collins and Gray, Byron and Shelley; they continued to color popular historical thinking, and they long held their place in the idiom of education, politics, and patriotism.

Since the progress of freedom is the progress of the race, Thomson begins Part II with a sketch of pre-history, describing the early state of man as patriarchal and pastoral. $\mathrm{He}$ does not argue out primitivism versus progress, though the issue confronts him at various points in all his major poems; ${ }^{1}$ but, in the words of his own topical outline, we find "the several Establishments of Liberty, in Egypt, Persia, Phoenicia, Palestine, slightly touch'd upon, down to her great 
Establishment in Greece." From this point he had frequent recourse to Rollin's Histoire ancienne. The publication of this famous and influential work extended from 1730 to 1738 . The catalogue of Thomson's library records "Hist. Ancienne par Rollin. tom. 1 \& 4 Par. 1731," and "Ditto, 8 first Toms, bound, Amst. 1730" (Nos. 182, 100). The dates given must be only of the earliest volumes in these groups. It is uncertain just how far Thomson's reading of Rollin had proceeded by the time he sent the various parts of Liberty to press, but it seems safe to assume that he knew the parts of the Histoire ancienne that had appeared in Paris and Amsterdam by 1733 . The latter part of the Histoire ancienne and the entire Histoire romaine (from 1738) do not qualify as sources for Liberty, though Thomson's library also shows "Histoire Ancienne, vol. 9, 10, 11, 12, 13, stitch'd, Paris, 1735," and "Hist. Romaine, par Rollin, vol. 1, 2, \& 3. stitch'd, Paris 1738" (Nos. 99, 98). At any rate, he was one of the earliest students to draw on Rollin's naïve and popular presentation of ancient history in terms of civic virtue and republicanism. Thereafter countless Whigs and liberals in Great Britain and America kept Rollin in the libraries and schools for over a century as a guide to the political and moral lessons taught by the ancient world. ${ }^{2}$

Thomson did not have to read far in the first volume of the Histoire ancienne to find the material he used for his lines on Egypt. He was immediately confronted with what in his libertarian philosophy was a conflict between primal Egyptian wisdom and Egyptian tyranny and superstition:

While there my Laws alone despotic reign'd, And King, as well as People, proud obey'd;

I taught them Science, Virtue, Wisdom, Arts;

By Poets, Sages, Legislators sought;

The School of polish'd Life, and Human-kind. (II, 51-55.) 


\section{Ancient History}

The first two lines are from a quotation in Rollin from Diodorus Siculus, to the effect that Egyptian monarchs were not absolute, but subject to law. ${ }^{3}$ The next three, commonplace though they are, are a condensation of Rollin:

L’Égypte a toujours été regardée parmi les anciens comme l'école la plus renommée en matière de politique et de sagesse, et comme l'origine de la plupart des arts et des sciences. Ses plus nobles travaux et son plus bel art consistaient à former les hommes. La Grèce en était si persuadée, que ses plus grands hommes, un Homère, un Pythagore, un Platon, Lycurgue même et Solon ces deux grands législateurs, et beaucoup d'autres qu'il est inutile de nommer, allèrent exprès en Egypte pour s'y perfectionner, et pour y puiser en tout genre d'érudition les plus rares connaissances. ${ }^{4}$

But the connection between superstition and civil tyranny is played up by Thomson, and he adapts to this point what Rollins says about the useless ostentation of the Pyramids in contrast to the useful public works of the Romans. ${ }^{5}$ His final lines on Egypt need explanation in terms of the source:

Then the great Dragon, couch'd amid his Floods,

Swell'd his fierce Heart, and cry'd.-"This Flood is mine,

'Tis I that bid it flow."-But, undeceiv'd,

His Phrenzy soon the proud Blasphemer felt;

Felt that, without my fertilizing Power,

Suns lost their Force, and Niles o'erflow'd in vain.

(II, 65-70.)

Thomson's original note on "great Dragon" is "The Tyrants of Egypt," expanded in 1750, probably by Lyttelton, to read, "An Eastern metaphor, us'd in Scripture to express an Egyptian tyrant." ${ }^{\prime}$ But Rollin gives us an interesting note on this note, in a comment on a long quotation from Pliny:

Le reproche que Pline fait ici aux Egyptiens d'avoir une vaine et folle complaisance dans les inondations de leur Nil, marque un de leurs caractères les plus particuliers, et me fait souvenir d'un bel endroit d'Ezéchiel, où Dieu parle ainsi à Pharaon, l'un de leurs rois: "Je viens à toi, grand dragon, qui te couches au milieu de tes fleuves, et qui dis: Le fleuve est à moi, c'est moi qui l'ai fait, c'est moi-même 
qui me suis créé." . . . Dieu voyait dans le coeur de ce prince un orgueil insupportable: un sentiment de sécurité, de confiance dans les inondations du Nil, d'une entière indépendance des influences du ciel. ${ }^{7}$

The brief references to Persia, Phoenicia, and Israel need not detain us as we pass on to "Nature's utmost Boast, unrival'd Greece," and to the idealization of the natural setting and of Greek philosophy, literature, and art, under the somewhat vaguely conceived fostering influence of liberty. It is not so much a question of what Greece really was, as of what Greece could be to the poet. The best tributes to Greek liberty in this period are in the opening passages of Collins's Ode to Liberty and Gray's Progress of Poesy, where the Pindaric tradition yields verse that is rapid, concentrated, elevated, and somewhat abstract. Thomson fails in concentration. He doggedly retails the circumstances, but they do not become the core of a generalized description, as in The Seasons, or the center of a brief allegory, as in the poems of Collins and Gray.

He turns then to his manuals, to the Plutarchan tradition of public virtue, to ideas of Greek government which had come down from classical history and political theory. $\mathrm{He}$ would need little but Plutarch for his Lycurgus, who

built, on the solid Base

Of equal Life, so well a temper'd State;

Where mix'd each Government, in such just Poise;

Each Power so checking, and supporting, Each;

That firm for Ages, and unmov'd, it stood,

The Fort of Greece! without one giddy Hour,

One Shock of Faction or of Party-Rage.

For, drain'd the Springs of Wealth, Corruption there

Lay wither'd at the Root.

(II, 113-21.)

Verbal parallels probably appear here with the current English translation of Plutarch: 


\section{Ancient History}

For the State which before had no firm Basis to stand upon, but lean'd one while towards an absolute Monarchy .... and another while towards a pure Democracy ... finding in this Establishment of the Senate a counterpoise which always kept things in a just aequilibrium, preserved a firm order and settlement. $^{8}$

The conception of the permanence of the Spartan state was common to Polybius, Cicero, Plutarch, and many a modern writer.9 "The City of Lacedaemon continued the chief City of all Greece for the space of five hundred Years, mainly by their strict Observance of Lycurgus's Laws." ${ }^{10}$

Thomson's idealization of Greece reaches its height in praise of the Athenian genius, but a political flaw is indicated.

There, passionate for Me, an easy-mov'd,

A quick, refin'd, a delicate, humane,

Enlighten'd People reign'd. Oft on the brink

Of Ruin, hurry'd by the Charm of Speech, Inforcing hasty Counsel immature,

Totter'd the rash Democracy.

$$
\text { (II, 144-49.) }
$$

This connects with Rollin's comment on the character of the Athenians, as shown in the condemnation of Socrates: "Il montre en même temps ce qu'il faut attendre d'un peuple doux, humain, bienfaisant dans le fond, car tels étaient les Athéniens; mais vif, fier, hautain, inconstant, mobile à tout vent et à toute impression, et dont on a raison de comparer les assemblées à une mer orageuse."11 The lines on the reforms of Solon go back to Plutarch, but here too Rollin is an intermediary. Solon, says Thomson,

with the Weight

Which the two Senates to the Public lent, As with an Anchor fix'd the driving State.

(II, 155-57.)

Thomson's note: "The Areopagus, or Supreme Court of Judicature, which Solon reformed, and improved; and the 


\section{Background of Thomson's Liberty}

Council of Four Hundred, by him instituted. In this Council all Affairs of State were deliberated, before they came to be voted in the Assembly of the People." Both text and note are closer to Rollin than to the English Plutarch: "Il crut que l'État, arrêté et affermi par ces deux puissants Corps, comme par deux bonnes ancres, ne serait plus si agité et si tourmenté, et que le peuple serait plus tranquille." And Solon "créa un second Conseil de quatre cents hommes ... devant lesquels on rapportait toutes les affaires, et où on les examinait mûrement, avant que de les proposer dans l'assemblée du peuple." 12

Thomson's praise of Athens involves his idealization of Greek culture as a whole, and here he turns aside from politics in the narrow sense. Athens and the other Greek states share the glory of the defeat of the Persians, and Thomson generalizes the idea of "noble Contention" for renown between Athens and Sparta which he finds in Rollin. ${ }^{13}$ Yet much of the glory belongs peculiarly to Athens. Here alone we find a city full

Of mirthful Quarrel and of witty War, Incessant struggled Taste refining Taste, And friendly free Discussion, calling forth From the fair Jewel Truth its latent Ray.

(II, 217-20.)

This is Shaftesbury's "Freedom of Wit and Humour," and the praise of Socrates in the lines that follow is probably based on Shaftesbury's remarkable analogy between the refinement of comedy and the progress of philosophy. ${ }^{14}$ Entirely in the spirit of Shaftesbury is the contrast between the bigotry of later priest-ridden ages and the Socratic method:

Deep thro' the human Heart, with playful Art, His simple Question stole; as into Truth, And serious Deeds, He smil'd the laughing Race.

(II, 228-30.) 


\section{Ancient History}

Praise of Greek poetry and music follows, with a long passage on the fine arts which will be discussed later.

In returning to the political theme Thomson presents briefly a contrast between ancient and modern Greece such as he had given for Italy. Even the climate has degenerated:

Neglected Nature fails; in sordid Want

Sunk, and debas'd their Beauty beams no more.

The Sun himself seems, angry, to regard,

Of Light unworthy, the degenerate Race;

And fires them oft with pestilential Rays;

While Earth, blue Poison steaming on the Skies,

Indignant, shakes them from her troubled Sides.

(II, 410-16.)

This is the political "pathetic fallacy" illustrated above in Chapter III. ${ }^{15}$ The circumstantial account of the decline of Greece then takes us back to Plutarch and Rollin. In describing the internecine strife of the Greek states, and their intrigues with Persia, Thomson's pattern is Plutarch's "Artaxerxes," with detail filled in from Rollin.

Peaceful in Susa, then, sat the Great King;

And by the Trick of Treaties, the still Waste

Of sly Corruption, and Barbaric Gold,

Effected what his Steel could ne'er perform,

Rous'd them to Civil War, or dash'd them down

To sordid Peace-Peace! that, when Sparta shook

Astonish'd Artaxerxes on his Throne;

Gave up, fair-spread o'er Asia's sunny Shore,

Their kindred Cities to perpetual Chains.

What could so base, so infamous a Thought

In Spartan Hearts inspire? Jealous, they saw

Respiring Athens rear again her Walls;

And the pale Fury fir'd them, once again

To crush this rival City to the Dust.

(II, 441-44, 451-60.)

441. Thomson's note: "So the Kings of Persia were call'd by the Greeks." Rollin: "Déjà les villes de Grèce ne regardaient dans leurs guerres que le Roi de Perse, qu'elles 


\section{Background of Thomson's Liberty}

appelaient le grand Roi, ou le Roi par excellence" (IV, 596). 442-44. Rollin describes the policy of Artaxerxes, "en répandant des sommes considérables parmi des peuples invincibles au fer et aux armes, mais non à l'or et aux présents des Perses" (IV, 302).

452. Thomson's note: “The Peace made by Antalcidas, the Lacedemonian Admiral, with the Persians; by which the Lacedemonians abandon'd all the Greeks establish'd in the lesser Asia to the Dominion of the King of Persia." Rollin, of the Peace of Antalcidas: "Ainsi les Lacédémoniens livraient au Roi ... tous les Grecs établis en Asie” (IV, 298).

453. Rollin: "ces hardies entreprises des Grecs dont nous parlerons bientôt, qui firent trembler Artaxerxe jusques sur son trône" (IV, 215).

458. Thomson's note: "Athens had been dismantled by the Lacedemonians, at the end of the first Peloponnesian War, and was at this time restored by Conon to its former Splendor." This note, and lines 457-60, combine two passages in Rollin: "Conon releva en peu de temps les murs d'Athènes, rétablit cette ville dans son ancien éclat. ... Sparta ne put voir sans une extrême douleur un rétablissement si glorieux. Elle regardait la grandeur et la puissance d'une ville anciennement rivale, et presque toujours ennemie, comme sa propre ruine" (IV, 297).

The extension of the catalogue of Greek worthies in the final text of Winter, written after 1738, shows the same process. The brief lines in praise of the Greeks in 1730 are entirely Plutarchan; later expansions and additions give more Plutarch, sometimes supplemented by Rollin. Extended illustration is unnecessary, but it may be noted for example that Timoleon is in 1730 "that attemper'd Hero, mild and firm," later "temper'd happy, mild and firm," an echo of the 
English Plutarch-"His natural Abilities for the War were so happily temper'd," etc. ${ }^{16}$ The post-1738 additions to the Greek catalogue are largely of "the last worthies of declining Greece," and fall in with the theme of the decline of liberty. Thomson's Cimon is practically all in Plutarch, and yet the line, "Modest and simple in the Pomp of Wealth," catches up expressions in Rollin's sketch of Cimon: "Modeste au milieu des plus grands emplois et des honneurs les plus éclatants, . . . simple et éloigné de tout faste dans le sein même de l'abondance et des richesses." ${ }^{\text {"17 }}$ Perhaps the reader will be ready to accept an unsupported statement that Thomson's Agis and Philopoemen are out of Plutarch. For Aristides, we may compare the lines:

\section{Who, even his Glory to his Country's Weal Submitting, swell'd a haughty Rival's Fame}

(Winter, 1744, ll. 465-66.)

with a sentence in Rollin: "Nous verrons bientôt qu'Aristide, loin de traverser secrètement son ancien rival, concourut avec zèle au succès de ses entreprises, et à sa gloire."18 And Phocion furnishes another instance:
Phocion the Good; in public Life severe,
To Virtue still inexorably firm;
But when, beneath his low illustrious Roof,
Sweet Peace and happy Wisdom smooth'd his Brow,
Not Friendship softer was, nor Love more kind.

(Winter, 1l. 484-88.)

The contrast between the two aspects of the hero's character is of course in Plutarch, but it is pointed up by Rollin:

Phocion, avec toute sa sévérité, qui le rendait en quelque manière intraitable quand il s'agissait des interêts de la République, était dans le fond si doux et si humain, que ses ennemis même le trouvaient toujours disposé à les secourir. On aurait dit qu'il y avait en lui un double homme, composé de qualités toutes différentes, et en apparence tout à fait opposés: l'homme public, armé de force, de fermeté, de zèle; 


\section{Background of Thomson's Liberty}

quelquefois même d'une vive indignation, et d'une sorte de roideur, inflexible pour maintenir la discipline dans toute sa vigeur; l'homme privé, plein de douceur, d'affabilité, de condescendance, de patience, et orné de toutes les vertus qui rendent la commerce de la vie agréable. ${ }^{19}$

In Thomson's progress of liberty two crucial steps are from Greece to Rome and from Rome to Britain. At both points the poet indulges in historical romance. In the transition from Greece to Rome this romance centers about Pythagoras; in the transition from Rome to Britain there is no central hero, but, as we shall see, an elaborate romantic conception of northern liberty.

At the beginning of Part III, then, Thomson plays freely with history and makes Pythagoras the carrier of his favorite ideas. The Contents begin thus:

As this Part contains a Description of the Establishment of Liberty in Rome, it begins with a View of the Grecian Colonies settled in the Southern Parts of Italy, which with Sicily constituted the Great Greece of the Antients. With these Colonies the Spirit of Liberty, and of Republics, spreads over Italy. . . . Transition to Pythagoras and his Philosophy, which he taught thro' these free States and Cities.

The progress of philosophy is linked with the progress of liberty in the lines on "the Samian Sage":

to him belongs

The brightest Witness of recording Fame.

For these free States his native Isle forsook,

And a vain Tyrant's transitory Smile,

$\mathrm{He}$ sought Crotona's pure salubrious Air,

And thro' Great Greece his gentle Wisdom taught;

Wisdom that calm'd for listening Years the Mind,

Nor ever heard amid the Storm of Zeal.

(III, 32-39.)

The tradition of Pythagoras as the great teacher of the Greek colonies in Italy was accessible in Cicero's Tusculan Disputations (V, iv). Rollin, however, helped Thomson to connect 
the departure of the philosopher from Samos and his settlement in Magna Graecia with the contrast between tyranny and freedom:

Il revint dans sa patrie, où il ne fit pas un long séjour à cause $\mathrm{du}$ gouvernment tyrannique qu'il y trouva établi par Polycrate, qui avait néanmoins pour lui tous les égards possibles, et qui faisait de son mérite le cas qu'il devait. Mais l'étude des sciences, et surtout de la philosophie, ne peut guère s'accorder avec la servitude, même la plus douce et la plus honorable. Il passa donc en Italie, et fit sa demeure ordinaire à Crotone. ... Tout le pays se ressentit bientôt de la présence de ce grave philosophe. ${ }^{20}$

It may be superfluous to add that Thomson's note on Great Greece, "The Southern Parts of Italy, and Sicily, so called because of the Grecian Colonies there settled," is verbatim from Rollin's geographical account: "Ils s'établirent aussi dans la Sicile, et dans une partie de l'Italie vers la Calabre; qui sont appellées pour cette raison la grande Grèce."21 Thomson's note on the last line quoted, "His Scholars were enjoined Silence for five Years," is also to be matched in Rollin, though naturally other accounts have this detail. And as for the important passage that follows, on the identification of Pythagorean attraction, the "Band of Love," with modern gravitation, on his monotheistic theology and his classification of the cardinal virtues-this remarkable group of ideas has other filiations which have been discussed elsewhere..$^{22}$ Thomson's interest in Pythagorean transmigration and even vegetarianism crops out rather oddly here, and parallels a long passage in Spring (ll. 336-78), where he follows Ovid's exposition of the doctrines of the "Samian Sage." It may be added that the character Galesus in Thomson's Coriolanus (1745) is described as a member of the philosophic school established by Pythagoras in Italy.

The great central theme of Roman history, as Thomson 
understood it, is not so much calculated to inspire a broad survey of culture as to call up a fairly rigid doctrine of the rise and fall of liberty, the cycle that runs from austerity to luxury and laxity, and from civic virtue to corruption. This traditional scheme is irradiated by Thomson's benevolist ethics, his exaltation of

The great the reigning Passion of the Free, That Godlike Passion! which, the Bounds of Self Divinely bursting, the whole Public takes Into the Heart. (III, 106-09.)

The heroes of the republican period, as presented by Plutarch, are done over in this ardent style; altruism suffuses their grim features, though this sentimental coloring sorts ill with the long story of Roman conquest and factional strife. Thomson treats his Roman heroes somewhat as he treats the great statues of antiquity. ${ }^{23}$ We may also compare this softening of rugged virtue to the sentimentalized treatment of the central figures in "hard" primitivism-the homely virtues of Swiss and Laplanders, even the fortitude of Vikings or American Indians. There is also a piquant contrast between simple country occupations and public spirit (Cincinnatus at the plow, or Numa called from his Sabine farm)-or between family affection and patriotism, notable in Thomson's treatment of the story of Regulus. The great general, sent as a prisoner to Rome to conclude a peace, advised his countrymen not to accept the enemy's terms, and then kept his pledged word to return to Carthage and to certain death. Thomson's tableau of the departure of Regulus is directly from Horace, guided perhaps by a note in Rollin. ${ }^{24}$ The whole theme is carried over from Liberty and presented again in the final version of Winter (11. 498-526), with the catalogue of worthies extending from Numa, who softened 
the rugged Romans, to the "unhappy Brutus, kind of heart," who slew his great friend in the public interest.

Though the emphasis is on austere republican virtue softened by altruism, imperial glory is included in the view. A geographical prospect of the Empire (III, 226-56) anticipates, though not with great success, the kind of topographical addition made in later versions of The Seasons. Thomson then describes at length (III, 257-319) the occasion when the Romans, led by Flaminius, restored the liberties of conquered Greece by proclamation at the Isthmian Games, a notable example of Roman virtue on the imperial scale. The whole passage is transcribed so closely from Plutarch's "Flaminius" that elaborate parallels need not be presented. But as a brief example, to show Thomson's use of the English Plutarch, compare the accounts of the celebration that followed the proclamation of liberty:

like Bacchanals they flew, Each other, straining in a strict Embrace,

Nor strain'd a Slave; and loud Acclaims till Night

Round the Proconsul's Tent repeated rung.

Then, crown'd with Garlands, came the festive Hours,

And Music, sparkling Wine, and Converse warm,

Their Raptures wak'd a-new.

(III, 294-300.)

"When they had tired themselves with Acclamations, all about his Pavillion, and Night was now come, whatever Friends or Fellow-Citizens they saw, they fell embracing and hugging them, and from that to feasting, and carousing together." ${ }^{25}$ The exultant speech in praise of Rome that follows in Thomson is verbatim from Plutarch, with some use of the account in Livy (XXXIII, xxxii-xxxiii). At this point Rollin is chronologically out of the question; his Histoire romaine, which of course includes this incident, was too late for Liberty. However, Rollin's Manière d'enseigner et 


\section{Background of Thomson's Liberty}

d'étudier les belles lettres (1726-28, English translation 1734) might have been in Thomson's hands by this time, in French if not in English, and here much is made of the magnanimous proclamation of Flaminius as one of the most glorious episodes in Roman history. ${ }^{26}$

It would be idle to seek an exclusive or even perhaps a dominant source for Thomson's account of Rome's corruption by luxury, the outbreak of civil strife, and the loss of liberty in the transition from republic to empire. These themes had long been commonplace, and to cite elaborate parallels from Plutarch, Livy, and Tacitus would be labor lost. ${ }^{27}$ Yet from Thomson's general practice it would appear probable that he had some current work of ready reference at hand. Such a manual is the Abbé Vertot's History of the Revolutions that happened in the Roman Republic, to use the title of the English translation of $1720{ }^{28}$ Vertot gave a popular description of the virtuous poverty of early Rome and the disasters that later overcame the state. ${ }^{29}$ His Introductory Discourse elaborates the theme of poverty as the guardian of liberty, and even in a highly generalized discussion yields parallels with Thomson.

By means of this voluntary Poverty, and a laborious Life, the Republic bred in her Bosom no Men but what were strong, robust, full of Valour, and who expecting nothing from one another, did by a mutual Independence, preserve the Liberty of their Country.

This Contempt of Riches in private Men grew to be a Maxim of Government: A Roman gloried in continuing in his Poverty, at the same time that he daily exposed his Life to increase the publick Treasure. Every Man thought himself sufficiently wealthy in the Riches of the State; and the Generals, as well as the common Soldiers, received their Subsistance only from their own little Patrimony which they cultivated with their own Hands: Gaudebat Tellus vomere laureato. ${ }^{30}$ 


\section{Ancient History}

Fruitful of Men, hence hard laborious Life, Which no Fatigue can quell, no Season pierce.

Hence, Independance, with his little pleas'd

Serene, and Self-sufficient, like a God;

In whom Corruption could not lodge one Charm,

While he his honest Roots to Gold preferred;

While truly rich, and by his Sabine Field,

The Man maintain'd, the Roman's Splendor all

Was in the Public Wealth and Glory plac'd.

$$
\text { (III, 134-42.) }
$$

This vein of panegyric connects with the exaltation of agriculture derived from Roman literature, especially from the Georgics. $^{31}$ The theme recurs in Livy, Pliny, Virgil, Cicero, Columella, and Plutarch, but the fact remains that Vertot was ready to hand. Passages adjacent to those just quoted from Thomson and Vertot may also be matched:

A Consul, at the Expiration of his Consulate, retain'd no more Authority than what his personal Merit gave him: And after having commanded the Armies of the Republic in chief, he was often seen to serve in those very Armies under his Successor.

Consuls, Dictators, still resign'd their Rule The very Moment that the Laws ordain'd.

soon as expir'd

The latest Hour of Sway; taught to submit, Into the Private Roman sunk the Chief. (III, 151-52, 155-56, 158.)

One striking borrowing from Horace appears in the figure of the oak, which Thomson applied to Britain a little later in "Rule Britannia":

This firm Republic, that against the Blast

Of Opposition rose; that (like an Oak,

Nurs'd on feracious Algidum, whose Boughs

Still stronger shoot beneath the rigid Axe)

By Loss, by Slaughter, from the Steel itself, Even Force and Spirit drew; smit with the Calm, The dead Serene of prosperous Fortune, pined. 


\section{Background of Thomson's Liberty}

The comparison comes from the lines which Horace attributes to Hannibal:

$$
\begin{aligned}
& \text { duris ut ilex tonsa bipennibus } \\
& \text { nigrae feraci frondis in Algido, } \\
& \text { per damna, per caedes ab ipso } \\
& \text { ducit opes animumque ferro. }{ }^{32}
\end{aligned}
$$

For the whole political pattern of Rome there was always Plutarch, who records the failures and tragedies as well as the triumphs of public life. Thomson's lines on the Gracchi (III, 347 ff., 390-95) are from Plutarch, as we might expect. But writers like Vertot perhaps keep the emphasis more steadily than Plutarch on the sudden reversal in Roman morals and the rapid deterioration of the state. A general impression that Vertot is being followed is confirmed in the passage on the last days of Sulla and the transition to the period of the Civil Wars.

In vain from Sylla's Vanity I drew

An unexampled Deed. The Power resign'd,

And all unhop'd the Commonwealth restor'd,

Amaz'd the Public, and effac'd his Crimes.

Thro' Streets yet streaming from his murderous Hand

Unarm'd he stray'd, unguarded, unassail'd,

And on the Bed of Peace his Ashes laid;

A Grace, which I to his Demission gave.

(III, 451-58.)

\section{Plutarch would serve well here:}

But the strongest Proof of his placing a much greater Confidence in his good Genius, or Fortune, than in any of his Exploits, is, that after the Murder of so many thousand Romans, after having introduced so many monstrous Innovations and Changes in the State, he had notwithstanding All This, the Boldness to lay down his Authority, and settle the Right of Consular Elections once more on the People. So that he not only came abroad, but in the Forum exposed his Person publickly to the People, walking up and down as a private Man. ${ }^{33}$ 


\section{Ancient History}

But Vertot is even closer:

[Sylla] was daring enough to divest himself of the Sovereign Power. He laid down the Dictatorship, and uncompell'd, reduced himself to a Level with a private Citizen, without fearing the Resentment of so many illustrious Families, the Heads of which he had destroy'd by his cruel Proscriptions. ... He, at the same Time, sent away his Lictors, dismiss'd his Guards, and, after that, continued walking in the Forum with some of his Friends, and before the Multitude, who, struck with Astonishment, look'd on so unexpected a Change, as on a Prodigy. In the Evening, he returned home by himself, and like a private Man; no one, among that great Number of Enemies he had created himself, daring to insult him. ... Sylla, after having shed so much Blood, died as quietly in his Bed, as the most peaceable Citizen of the Commonwealth could have wish'd to do. ${ }^{34}$

Thomson continues:

But with him dy'd not the despotic Soul.

Ambition saw that stooping Rome could bear

A Master, nor had Virtue to be free.

(III, 459-61.)

As does Vertot:

But the dangerous Example of a simple Citizen, who had found means to raise himself to Empire, and maintain himself therein, made those that followed him sensible, That the Romans could bear a Master; which was the Ground of more Revolutions. ${ }^{35}$

For Thomson's comparison of Pompey and Caesar:

The shameful Contest sprung; to whom Mankind Should yield the Neck: to Pompey, who conceal'd

A Rage impatient of an equal Name;

Or to the nobler Caesar, on whose Brow

O'er daring Vice deluding Virtue smil'd, And who no less a vain Superior scorn'd.

(III, 473-78.)

Vertot supplies the point:

Moderate on every other Account, [Pompey] could not bear any Body should pretend to an equal Share of Glory: He 
was offended at any Equality therein. . . . This Jealousy of Command created him a great many Enemies, of whom Caesar was afterwards the most dangerous, and formidable. The one, as we have seen, could bear no Equal; the other no Superior. ${ }^{36}$

Here Thomson approaches the end of his Roman survey; he pays little attention to the Empire. But Vertot is the second French writer-Rollin being the first and Rapin de Thoyras the third-who helped him to glorify British liberty. 


\section{THE FINE ARTS}

7 HOMSON'S view of the fine arts in Liberty, part of the 1 paraphernalia of the Grand Tour, overlaps with the historical and political themes. The identity or harmony of the various aspects of cultural history is over-emphatically asserted. Somewhat as in the Essay on Criticism or the Essay on Man, a series of identities is set up, Nature-Reason-the Rules-Divinity, or Nature-Genius-Freedom, and various questions then remain unanswered,-how error comes to be, and how inconsistencies among these manifestations of excellence are resolved. We have the problem of making the crossreference between the aesthetic norm and the ethical-religious norm. Perhaps such problems remain unsolved under any system, but they are particularly insistent under neo-classicism. The critic is called on to make good an assertion of unity or harmony; history and society give diversified prospects which have to be brought under an over-simple scheme.

The guide-books and manuals, arbiters of taste for the student and the tourist, took over the aesthetic code that had been worked out in seventeenth century France. In the fine arts there was no counterbalancing native tradition which could affect the course of English criticism, as Shakesspeare profoundly modified the impact of Corneille on Dryden's literary opinions. But neo-classical art criticism accorded well with the broadly moral aspects of Thomson's theme. There was felt to be an affinity between a Plutarchan hero and a Greek statue, or between a hero of Corneille and a picture by Poussin; the imitation of ancient models in art was also a revival or recovery of ancient virtue. The system was tight and highly abstract, and we can say that it was in 
danger of being frigid and formal; yet even on the abstract level it was animated by the enthusiastic quest for the Idea which Thomson found in Shaftesbury, and also, as will appear, by the emphasis on expression which developed within the strictest neo-classical orthodoxy.

The Sale Catalogue to which we have often referred gives valuable evidence about the cultivation of Thomson's artistic tastes. Titles of books are given below first as in the Catalogue and then in fuller form.

113 Reflexions sur la peinture \& poesie, 2 tom. Paris 1709

Abbé Du Bos, Réflexions critiques sur la poésie et sur la peinture, 2 tom., Paris, 1719. [This identification assumes a misprinted date in the Catalogue, and a slightly inaccurate transcription of the title.]

120 Le Vies des Peintres, par Piles Abreg. Paris 1715 Roger de Piles, Abrégé de la vie des peintres, avec des réflexions sur leurs ouvrages et traité du peintre parfait, Paris, 1715. [The first edition, Paris, 1699, had been translated as The Art of Painting, and the Lives of the Painters, London, 1706.]

121 Cours de Peinture, Paris 1708

Roger de Piles, Cours de peinture par principes, Paris, 1708. [Translated as Principles of Painting, London, 1743.]

137 Williams on Designing the Passions, London 1734 Charles Le Brun, Painter, A Method to Learn to Design the Passions, trans. John Williams, London, 1734. [Méthode pour apprendre à dessiner les passions, Amsterdam, 1702.]

143 Vignola Reigles d'Architecture, Paris

Giacomo Barozzi, called "Il Vignola," Reigles des cinq ordres d'architecture. [Translated from the Italian, several editions.] 


\section{The Fine Arts}

194 Les Vies \& Ouvrages des Peintres, 2 tom. Paris 1685 André Félibien, Entretiens sur les vies et sur les ouvrages des plus excellens peintres, anciens et modernes, Paris, 1666-88.

222 Painting illustrated, London 1685

William Aglionby, Painting Illustrated in Three Diallogues, Containing some Choice Observations upon the Art, London, 1685.

247 Palladio's Architecture, Italian Venet. 1601

Andrea Palladio, I quattro Libri dell Archittetura [many editions].

251 Turnbull on Antient Painting, Large Paper Lond.

George Turnbull, A Treatise on Ancient Painting, London, 1740.

256 A Book of Drawing, Limning, \&c.

A Book of Drawing, Limning, Washing or Colouring of Maps and Prints, and the Art of Painting, etc., London, 1660; another edition, 1666.

To these titles we may add, as almost inevitably known to Thomson, Dufresnoy's De Arte Graphica, translated into French and annotated by De Piles, and then put into English by Dryden, with an important preface (1695, 2nd edition 1716). ${ }^{1}$ Highly probable, too, is Thomson's knowledge of Jonathan Richardson's Essays on the Theory of Painting (1715, 1725), and his Two Discourses (1719). Charles Lamotte's Essay upon Poetry and Painting (Dublin, 1742) remarks that the work of drawing a parallel between the two arts "has already been done by such masterly Hands as Junius, Félibien, Monsieur De Pyles, Mr. Dryden, and the ingenious Mr. D. B." ${ }^{2}$ The first reference is to Junius $D e$ Pictura Veterum (1637), the last to the Abbé Du Bos, and this brief list no doubt includes the best known works on the subject. 
In the face of these authorities it need hardly be remarked that Thomson dismisses mediaeval art contemptuously, but a significant passage taken from the travel-books may be noted. The decline of the Roman Empire, Thomson remarks, means the decline of sculpture, and he mentions a famous instance:

what Sculpture rais'd

To Trajan's Glory, following Triumphs stole; And mix'd with Gothic Forms, (the Chissel's Shame) On that Triumphal Arch, the Forms of Greece.

(III, 509-12.)

He adds the note: "Constantine's Arch, to build which, That of Trajan was destroy'd, Sculpture having been then almost intirely lost." The Arch is often mentioned, but Wright points out its significance for the history of art:

As this Arch had its principal Ornaments from the Ruins of that of Trajan, in whose Time Sculpture did highly flourish; so, where they fell short, to compleat the Design of the Architect, and that there might be somewhat of Constantine's own Story seen in an Arch erected to his Honour, some additional ones were carv'd by the Artists of that time, which are most vile; at least they appear so in presence of the others. ${ }^{3}$

Du Bos' Réflexions has a passage to the same effect, though he does not use the term "Gothic" as Thomson does, but says rather that the added pieces of sculpture were "fort audessous du bon Gothique."*

The seven principal statues of antiquity, according to Jonathan Richardson, are the Meleager, the Venus de Medici, the Apollo Belvedere, the Farnese Hercules, the Dying Gladiator, the Laocoon, and the Antinous. ${ }^{5}$ The central position of these works is thus indicated by Félibien:

Le Poussin n'etait pas si présomptueux de croire que sur ses seules idées il put former des figures aussi accomplies que 


\section{The Fine Arts}

celles de la Vénus de Medicis, du Gladiateur, de l'Hercule, de l'Apollon, de l'Antinous, des Lutteurs, et de plusieurs autres statues que l'on admire tous les jours à Rome. ${ }^{6}$

When George Turnbull translates this passage in his Treatise on Ancient Painting he makes the inevitable addition of the Laocoon, or follows a text that does so. ${ }^{7}$ In his section on the Renaissance Thomson presents this classic series, giving us the only long descriptions of works of art in the whole course of his poetry; he enumerates the Hercules, the Meleager, the Fighting Gladiator, the Dying Gladiator, the Apollo Belvedere, the Flora, the Venus de Medici, and the Laocoon (IV, 134-206). This list corresponds to the group of "Antique Drawings" by an artist named Castelli included in Thomson's collection of prints, except that the poet adds the Flora, and omits the Antinous and the Perseus and Andromeda. Dr. Larrabee offers the interesting comment: "The number of lines apportioned to a statue indicates rather well its relative esteem at the time, while the order of mention was intended to suggest the order of discovery in the Renaissance."8

In Part II Thomson had already told of the rise of Greek art. Here the underlying principle is conceived to be rigorous selectivity working toward the embodiment of the ideal forms of nature in a single work which exacts years of toil.

Selecting Beauty's Choice, and That again Exalting, blending in a perfect Whole, Thy Workmen left even Nature's Self behind.

From Those far different, whose prolific Hand

Peoples a Nation; They for Years on Years,

By the cool Touches of judicious Toil,

Their rapid Genius curbing, pour'd it all

Thro' the live Features of one breathing Stone.

There, beaming full, it shone; expressing Gods:

Jove's awful Brow, Apollo's Air divine,

The fierce atrocious Frown of sinew'd Mars,

Or the sly Graces of the Cyprian Queen. 
But these ideal forms show intense animation and a precise use of expressive detail:

Minutely perfect all! Each Dimple sunk, And every Muscle swell'd, as Nature taught.

In Tresses, braided gay, the Marble wav'd;

Flow'd in loose Robes, or thin transparent Veils;

Sprung into Motion; soften'd into Flesh.

Was fir'd to Passion, or refin'd to Soul.

These marbles are not in repose, but in a state of arrested motion; they are not, in the poet's intention, cold, but "fired" or warmed. The long description of the Laocoon is filled with such phrases as "imperious Passion," "Bitterness of Pain," "Fell Despair," "full-extended Fury," "the soft Rage of younger Passions." This view was traditional in the early criticism of the statue. ${ }^{9}$ A complete or ideal expression of human feeling was taken to point to a reconciliation of the dynamic particular and the static universal. At the same time the study of the individual work of art drew the observer away from the central issue of public virtue. The libertarian would have to content himself with the ethical overtones of sublimity or ideality. He might find idealized leadership in the "Legislator's awful Grace" of Michael Angelo's Moses (I, 212-13), but he does not pursue the topic, or make the vain attempt to confirm classical republicanism by an appeal to the Renaissance art of Italy and France.

Yet it cannot be denied that Thomson feels moral elevation in the view that modern painting began with an imitation of the forms of ancient sculpture, even though the freedom of the great artist is not political freedom. Liberty must praise the Age of Louis XIV, and tell

From Rome, awhile, how Painting, courted long,

With Poussin came; Ancient Design, that lifts

A fairer Front, and looks another Soul.

$(\mathrm{V}, 500-02$. 
The plan of telling of the rise of the arts both in ancient and modern times, in Parts II and IV, obliges Thomson to give parallel accounts of Greek and Italian painting. He begins with some of the famous ancient pictures: the Helen of Zeuxis, selected from the individual beauties of various models; the Venus of Apelles, depicted with the grace that was his unique quality; the Jalysus of Protogenes. All these details go back to Pliny, and were frequently repeated; but in order to put Thomson's work in its immediate setting, it is worth pointing out that he seems to follow Félibien for the anecdote of Protogenes. His note to Liberty, II, 322, reads:

When Demetrius besieged Rhodes, and could have reduced the City, by setting fire to that Quarter of it, where stood the House of the celebrated Protogenes; he chose rather to raise the Siege, than hazard the burning of a famous Picture call'd Jasylus [sic], the Master-piece of that Painter.

With this we may compare Félibien:

Mais pour achever ce que j’ai à vous dire de Protogène, ce Tableau de Jalysus dont jai parlé fut le salut de toute la ville de Rhodes lors que Demetrius l'assiégea. Car ne pouvant être prise que du côté où était la maison de Protogène, ce Roi aima mieux lever le siège que d'y mettre le feu et de perdre un ouvrage si admirable..$^{10}$

Thomson goes on to say that the portrayal of the human form in painting was inspired by sculpture:

First elder Sculpture taught her Sister Art Correct Design; where great Ideas shone, And in the secret Trace Expression spoke: Taught her the graceful Attitude; the Turn, And beauteous Airs of Head; the native Act, Or bold, or easy; and, cast free behind, The swelling Mantle's well-adjusted Flow. (II, 323-29.)

This passage refashions the history of ancient art on the 
model of the classical revival of the Renaissance. The terms used are commonplaces in French academic criticism. As a parallel to Thomson's phrases, which sound somewhat like a translation, we may note that Roger de Piles says that painters should imitate from ancient sculpture "les beaux airs de teste et leurs expressions, ... . la correction du Dessin, les plis des draperies, et le grand goust qui accompagne toutes ces choses."11

Within these conventional terms lurks a distinction between emphasis on correctness of proportion, as judged by an almost geometrical ideal drawn from the Greeks, and emphasis on expression of feeling. Félibien includes in design exact anatomical analysis, the expression of feeling, and the correct ordonnance of garments and other objects in the picture-all this, he adds, without benefit of color. ${ }^{12}$ Thus implied and expressed oppositions arose between correctness and expressiveness, and between the relative claims of design and color. ${ }^{13}$ Of two of Thomson's chief guides it may be said that Félibien emphasizes the primacy of classical design, with Poussin as the master painter, and that De Piles, without seeking to disparage the ancient models, lays more emphasis on color, exalts Titian and Rubens, and warns the painter to make due allowances for a translation of the themes of sculpture into his own medium. ${ }^{14}$ Thomson, it will appear, was not conscious of a sharp opposition here, and was disposed to be eclectic.

In his account of ancient art Thomson brings in poetry to enlarge the scope of painting and sculpture:

Then the bright Muse, their eldest Sister, came;

And bad Her follow where She led the Way;

Bad Earth, and Sea, and Air, in Colours rise;

And copious Action on the Canvas glow:

Gave her gay Fable; spread Invention's Store;

Inlarg'd her View; taught Composition high, 


\section{The Fine Arts}

And just Arrangement, circling round one Point, That starts to Sight, binds and commands the Whole.

(II, 330-37.)

This, we feel, is markedly literary in bias, ut pictura poesis in a very broad sense, with poetry enjoying priority. Color and design are both conceived in terms drawn from description and narration; it is on the model of poetry that the fine arts become descriptive and dramatic. Dufresnoy and Dryden practically equate painting with dramatic poetry, and Thomson's account may be connected with Dryden's remarks in his Preface to Dufresnoy, where he bases his parallel of the two arts on invention, disposition or composition, and the centering of the work about a principal figure. The next step in Thomson's sequence is the alliance of "the heavenly Muse" with the muses of poetry, painting, and sculpture to portray "heroic Deeds" and "moral Beauties," and thus to bring the arts into the service of Public Virtue (II, 338-57). To these lines Thomson added in 1738 a remarkable passage on landscape painting which will be discussed later in the present chapter. This extension takes him beyond the pale of the Academy, but the union of sculpture, painting, and poetry in Part II is thoroughly in the French academic spirit. "It was actually the French theorists of the seventeenth century who first declared the noble subject to be a sine qua non of the grand style that aimed at universal truth through the imitation of 'la belle nature'; for the great events of scripture, or of Greek and Roman fable and history, ... easily adapted themselves to ideal representation." ${ }^{15}$ And thus Félibien says of Poussin's pictures: "Ces sujets travaillés poétiquement avec ce beau feu et cet art admirable qu'on peut dire si conforme à l'ésprit des Poètes, des Peintres, et des Sculpteurs anciens ... rendaient célèbre le nom du Poussin." ${ }^{16}$ 
In his account of the revival of painting in modern times we again see Thomson taking over the neo-classical view. After the passage on the rediscovery of the great ancient statues, and the brief lines on Michael Angelo as a sculptor, he sketches the history of Italian painting. Passing over the "barren and dry" beginnings of painting as it emerged from the cloisters, he proceeds to set forth briefly an eclectic view of the subject:

Arts gradual gather Streams. Enlarging This

To each his Portion of her various Gifts

The Goddess dealt, to none indulging All;

No, not to Raphael. At kind Distance still

Perfection stands, like Happiness, to tempt

Th' eternal Chace. In elegant Design

Improving Nature; in Ideas fair,

Or great, extracted from the fine Antique;

In Attitude, Expression, Airs divine;

Her Sons of Rome and Florence bore the Prize.

To those of Venice She the magic Art

Of Colours melting into Colours gave.

Theirs too it was by one embracing Mass

Of Light and Shade, that settles round the Whole,

Or varies tremulous from Part to Part,

O'er all a binding Harmony to throw,

To raise the Picture, and repose the Sight.

The Lombard School, succeeding, mingled both.

(IV, 227-44.)

To the last line quoted he adds a note, "The School of the Caracci," which thus occupies a favored though not necessarily a supreme position in his account. The high position thus given to Annibale Carracci and his Bolognese school reflects the widespread preference for a formula and an inclusive code. The French classical school turned to the Bologna of the Carracci, and was disposed to pass over Florence and Venice and to dwell on the Rome of Giulio Romano and Poussin rather than the Rome of Raphael. ${ }^{17}$ In its extreme form, this position entailed an emphasis on 
historical and formal dignity, and a preference for design over color. As transmitted to Thomson, however, the rigors of the Poussinists have been modified by the eclectic views of Roger de Piles. Thomson's division of schools and the attribution of desirable qualities among the schools are close to De Piles' Abrégé of 1715 . This edition was in Thomson's library, and here perhaps we can claim proximate background, something closer than general background though not necessarily exclusive source. With the first ten lines quoted above, compare De Piles on the Roman school:

Or il est certain que les ouvrages les plus estimés qui soient dans Rome, sont ce que nous appellons Antiques et les ouvrages Modernes qui les ont imités, soit en Sculpture, soit en Peinture. Toutes ces choses consistent principalement dans une source inépuisable de beautés du Dessein, dans un beau choix d'Attitude, dans la finesse des Expressions, dans un bel ordre de Plis, et dans un style élevé où les Anciens ont porté la Nature, et après eux les Modernes depuis près de deux siècles. Ainsi ce n'est pas merveille si le Goût Romain étant extrêmement occupé de toutes ces parties, le coloris qui ne vient que le dernier, n'y trouve plus de place. L'esprit de l'homme est trop borné, et la vie est trop courte pour approfondir toutes les parties de la Peinture, et les posséder parfaitement toutes à la fois. ${ }^{18}$

De Piles then goes on to contrast with the Romans the Venetian school of colorists. A matter of names is significant here: he adds that he had formerly identified the Venetian and the Lombard schools, but that now he makes them distinct. ${ }^{19}$ His earlier account, simply opposing to Roman design Venetian or Lombard color, appears in his notes on Dufresnoy, and is reflected in Dryden's lines “To Sir Godfrey Kneller":

Thence rose the Roman and the Lombard Line;

One colour'd best, and one did best design. Raphael's, like Homer's, was the Nobler part, But Titian's Painting looked like Virgil's Art. 
Thy Genius gives thee both; where true Design,

Postures unforc'd, and lively Colours joyn. ${ }^{20}$

Félibien, like the earlier De Piles, does not distinguish a Venetian from a Lombard school, and furthermore he makes the Roman school supreme. ${ }^{21}$ But De Piles, as early as his commentary on Dufresnoy, moved toward a compromise, and made Annibale Carracci the great exemplar of the ideal combination of qualities drawn from the various schools. "The laborious and diligent Annibal Caracci, has taken from all those great Persons already mention'd whatsoever Excellencies he found in them, and, as it were, converted their Nourishment into his own Substance." ${ }^{\prime 2}$ In Jonathan Richardson's Theory of Painting we have Florence and Rome for design, the Venetian, Lombard, and Flemish schools for coloring, the Bolognese school of the Carracci for the synthesis. ${ }^{23}$ But in the use of "Lombard" to designate the school of the Carracci, Thomson is closer to the later De Piles.

For Thomson's account of the Venetian use of chiaroscuro and the blending and massing of colors, Dufresnoy and De Piles' commentary may be sufficient. Here "Union of Colours" is said to be characteristic of the Venetian school; and in subjects containing many figures the painter is directed "to dispose Things by great Masses of Lights and Shadows, and Union of Colours." ${ }^{24}$ Here "great Shadows" are called "Reposes" because they rest the sight, and one injunction is that "there be so much Harmony, or Consent, in the Masses of the Picture, that all the Shadowings may appear as if they were but one." The connection of Thomson's "Colours melting into Colours" with chiaroscuro is shown clearly by De Piles' comment on the passage just quoted: "Whatsoever is found in those great Shadows, 
should partake of the Colours of one another, so that the different Colours which are well distinguish'd in the Lights, seem to be but one in the Shadows, by their great Union." ${ }^{25}$

The painters represented by prints in Thomson's collection, probably made for the most part during the early 1730 's, would be thus distributed, following a rough classification based on De Piles and Félibien:

Rome and Florence: Michael Angelo 1, Parmegiano 1, Poussin 8, Raphael 7, Romanelli [?] 1, Giulio Romano 3, Sacchi 1, Da Vinci 1, Feti 1-total 24.

Venice: Titian 2, Veronese 2-total 4.

Lombard: Albani 5, Annibale Carracci 5, Correggio 3, Domenichino 8, Guido Reni 3, Mola 1-total 25.

Carlo Marotti (Marotta) is represented by 11 prints. His great popularity came at the turn of the century, and he is not classified by Félibien and De Piles. A Bolognese, he worked in Rome, and might be either "Lombard" or "Roman" in Thomson's scheme.

We note the heavy predominance of "Roman" and "Lombard," and it may be added that the subjects of the pictures show a dominant interest in the heroic and sentimental treatment of classical, historical, and Biblical subjects. One looks in vain for the landscapes of Lorraine, Poussin, and Salvator Rosa. At least Thomson was not a pioneer in collecting prints of the works of this eminent group, and the evidence suggests that Miss Manwaring's claims for Claudian and Salvatorian influences in Thomson's early work must be considerably toned down. It is true that the description of the Swiss Alps (IV, 348-62) is in the new manner, and an important addition in 1738 is of the same kind, a modern landscape imputed to Greek painting:

to Rural Life

The softer Canvas oft repos'd the Soul. 
There gayly broke the Sun-illumin'd Cloud;

The less'ning Prospect, and the Mountain blue,

Vanish'd in Air; the Precipice frown'd, dire;

White, down the Rock, the rushing Torrent dash'd;

The Sun shone, trembling, o'er the distant Main;

The Tempest foam'd, immense; the driving Storm

Sadden'd the Skies, and, from the doubling Gloom,

On the scath'd Oak the ragged Lightning fell;

In closing Shades, and where the Current strays,

With Peace, and Love, and Innocence around,

Pip'd the lone Shepherd to his feeding Flock:

Round happy Parents smil'd their younger selves;

And Friends convers'd, by Death divided long. (II, 349-63.)

This points forward to the oft-quoted lines on the painters in The Castle of Indolence:

Whate'er Lorrain light-touch'd with softening Hue,

Or savage Rosa dash'd, or learned Poussin drew.

(I, xxxviii)

Not Titian's Pencil e'er could so array,

So fleece with Clouds the pure Ethereal Space.

(I, xliv)

Of these, Poussin and Titian come down naturally from the comments on painting in and behind Liberty. The names of Lorraine and Salvator Rosa indicate something of a shift in Thomson's tastes and interests, probably in the course of the $1730{ }^{3}$ s. ${ }^{26}$ Since the matter has been considerably discussed, the point may be noted in detail. Félibien is unfavorable to Salvator; he did battles well, says the critic, but "n'était pas agréable dans les autres sujets. Il faisait assez bien les ports de mer et les paisages, néanmoins toujours d'une manière bizarre et extraordinaire." ${ }^{27}$ Early praise is sometimes apologetic, since landscape was ranked below the history piece:

Ingenious Rosa who was wont to paint Heroes, and Histories, and many a Saint, Now lowers his great and noble Vein, 
To Landscape, and to Views Campane.

Dost thou paint Woods and Forests? Know

Thy Subject, Rosa, is not low.

Woods of a Consul worthy are,

And rude things may require thy Care,

Thy cultivating Hand will make them fair. ${ }^{28}$

As far as we can make out a chronology, Thomson moves in the 1730 's toward a view expressed by Jonathan Richardson in 1722: "Salvator Rosa has generally chosen to represent a sort of Wild and Savage Nature; his Style is Great, and Noble." ${ }^{29}$ At any rate, in 1740 Thomson found the writings and theories about art that he was following conveniently brought together in George Turnbull's Treatise on Ancient Painting, a work to which he and his friends subscribed, which gives a review of the entire background of Liberty, and which goes so far as to praise that poem. ${ }^{30}$ Turnbull copies Félibien on Salvator, but gives the comment a more favorable turn: "Who does not see in Salvator Rosa's Pictures, the Savageness of his Imagination? His Genius led him most strongly to paint Battles. He painted likewise Paisages and Sea-ports; but always in a whimsical, wild, and savage Taste." And a little later: "And Salvator Rosa should have painted for me several Battles, and a great Variety of wild savage Prospects." ${ }^{31}$ These passages help us to make the transition from the lines on painting in Liberty to the landscapes of The Castle of Indolence. 


\section{NORTHERN LIBERTY}

THOMSON is the heir of a double tradition of liberty, 1 the classical republican doctrine and the conception of a native liberty transmitted from forefathers variously described as Scythian, Gothic, Saxon, or Scandinavian. For the first, we have had recourse to Fink's excellent monograph, The Classical Republicans; the second has been learnedly studied by Dr. Samuel Kliger. ${ }^{1}$ Both traditions had long been commonplace in English political discussion, and are involved with Thomson's tendentious view of English history. Though he does not devote a separate section of his poem to the theme of northern liberty, the subject is of major importance for the general scheme of his progress or prospect.

The cult of the North involves a tangle of historical and political ideas that cannot be fully displayed here. An important distinction for our purpose is to be made between spontaneous or lawless liberty, and civic liberty, or liberty under law. The latter is the English way, of course, yet both classical and mediaeval precedents also pointed to a liberty apart from constituted law, asserting itself under an unwritten law or a law of nature. There are various intermediate positions here: actual political positions lie somewhere between absolute freedom and absolute incorporation into the state. Without abandoning the ordered institutions of mankind, the commentator might be moved by animus against the powers that be, by a desire to glorify national origins, by a moral preference for the earlier phase of the cycle that leads from civic virtue to corruption and luxury, by the various modes of primitivistic thought. There is an underlying similarity between the classical and the north- 
ern traditions of liberty. We can in fact pass from the Plutarchan hero to what Toynbee disrespectfully calls "The History of that Virtuous and Provident Creature Nordic Man, who followed the retreating Ice Cap because he wanted to harden his Moral Fibre." ${ }^{\prime 2}$ There is a dual conception of the hero as a hardy individual who becomes a conqueror or at least never surrenders, and on the other hand as a culture-hero and law-giver. It is in troubled times that great epics are produced, says Thomas Blackwell, because it is in such times that heroic characters appear.

The Times of such Struggles have a kind of Liberty peculiar to themselves: They raise a free and active spirit, which overspreads the Country: Every Man finds himself on such Occasions his own Master, and that he may be whatever he can make himself. He knows not how high he may rise, and is unawed by Laws, which are then of no Force. ${ }^{3}$

This, Blackwell says in his Index, is "a peculiar species of Liberty"; his usual application of the term is in line with Shaftesbury and Whig panegyric-"A Land of Arts . . . blooming in the native Grace and Vigour which is the Gift of Liberty and unlimited Commerce." In contrast to the corruption of declining Rome, however, or of any over-civilized period, we have the figures of the undaunted Cato or the tyrannicide Brutus sword in hand, and following hard upon them the barbarian from the North who, by his conquest of the degenerate Empire, reincarnates original Roman virtue. The two are linked in Thomson's plan by the idea of the retreat of Liberty. Some familiar lines in Lucan set the theme:

While Liberty, long wearied by our crimes, Forsakes us for some better barbarous climes; Beyond the Rhine and Tanais she flies, To snowy mountains and to frozen skies. ${ }^{5}$ 
A setting of this kind appears at the end of James Ralph's [?] poem, The Loss of Liberty (1729), where the Genius of Liberty, leaving the ruins of Rome,

with Horror shunn'd

The odious Landscape, and prefer'd the Waste

Of hideous Mountains, the stupendous, rude

Misshapen Prospect of the rocky Wonders,

The dire Confusion, the enormous Grouspe

Of Terrors, Nature's most unfinish'd Heap!

Prefer'd this wildest Haunt of Liberty,

To all the transient Pomp of fallen Rome. ${ }^{6}$

The theme dominates the story of Cato, as we have noticed, and is stated at length in the Prologue to the Germanicliberty play Arminius (1740) by Thomson's friend William Paterson.?

This is the proper habitat for a hero who is to illustrate the primal virtue of liberty. Historically and geographically it sets the background for the great theme of the barbaric conquest and the ensuing renovation of Europe, the translatio or course of Empire. Thomson's Goddess, at the end of Part III, describes her own flight to Scythia and Sarmatia, with elaborate geographical details perhaps drawn in part from Scheffer's Lapponia. ${ }^{8}$ The main historical theme is stated thus:

And there a Race of Men prolific swarms,

To various Pain, to little Pleasure us'd;

On whom, keen-parching, beat Riphaean Winds;

Hard like their Soil, and like their Climate fierce;

The Nursery of Nations!-These I rous'd,

Drove Land on Land, on People People pour'd;

Till from almost perpetual Night they broke,

As if in Search of Day; and o'er the Banks

Of yielding Empire, only Slave-sustain'd,

Resistless rage'd, in Vengeance urg'd by Me.

(III, 530-39.)

Later, in speaking of the development of the free institu- 
tions of Britain, Thomson puts this theme into its political context:

Had work'd that general Liberty, that Soul, Slow 'till then, alone,

Which generous Nature breathes, and which, when left

By $\mathrm{Me}$ to Bondage was corrupted Rome, I thro' the Northern Nations wide diffus'd.

Hence many a People, fierce with Freedom, rush'd

From the rude Iron Regions of the North,

To Lybian Desarts Swarm protruding Swarm,

And pour'd new Spirit thro' a slavish World.

(IV, 797-805.)

These passages are virtually repeated in the final text of Winter:

Wide o'er the spacious Regions of the North, That see Bootes urge his tardy Wain,

A boisterous Race, by frosty Caurus pierc'd, Who little Pleasure know and fear no Pain, Prolific swarm. They once relum'd the Flame Of lost Mankind in polish'd Slavery sunk, Drove martial Horde on Horde, with dreadful Sweep

Resistless rushing o'er th' enfeebled South, And gave the vanquish'd World another Form.

(Winter, 1744, 11. 844-52.)

An ultimate source is the reference in Jordanes' history of the Goths to the island "Scandza" as the "vagina gentium," the "hive of nations." With this idea were connected theories about the hardiness and vigor produced by the northern climate as a cause of the fecundity of northern nations, ${ }^{10}$ and about the primal virtues of these Goths or Scythians. Such ideas came to Thomson largely though not exclusively through Sir William Temple and Viscount Molesworth. In this connection it is interesting to note some statements in a somewhat obscure book that happened to be in Thomson's library, Carl Johann von Blomberg's Account of Livonia (1701). Blomberg, in his opening letter, connects the ideal- 
ization of the hard northern climate with fecundity and liberty:

Though the Climate may temper and allay immoderate Heats, yet it is evident, by the numerous increase of its Inhabitants, that neither the Temper of the Men, nor the Product of the Earth suffers by the Frigidity of the Region; and History speaks with Astonishment, of the numberless Inundations of these Northern People, that over-ran all the South of Europe, and the amaz'd World wondered what Land could furnish such multitudes.

For though the most Northern parts of Europe, by their distance from the Sun, do not receive its Rayes in that plenty and vigour, as to become a hot Clime, yet it has the advantage of being a Fertile and Healthy one. And that Great God whom Noah promised to enlarge Japhet, did it by sending them into these Regions, where they increased so exceedingly, that some Writers have not unworthily call'd these Countries, Officinas Gentium, the Shops or Magazines of Nations, and also Vaginas Gentium, the Scabbards of Nations, and from whence such a multitude of Warlike People have been drawn or extracted: These cold Regions producing a more prolifick and vigorous Generation of Men, than the Eastern or Southern.

That these Provinces have brought forth early and brave Inhabitants, great Lovers of their Liberty, as they are to this Day, may be gathered out of the most Ancient Swedish and Danish Histories. ${ }^{11}$

In this early phase the emphasis is on primitive barbarous energy rather than on political formulas for liberty.

As Beck points out, a basic connection is assumed here between early Scandinavian history and the conquest of Rome, ${ }^{12}$ and this goes back to the general confusion attendant on the term "Gothic" which blanketed the whole northern theme. The infiltration of Scandinavian or "Gothic" themes into English literature fell in with pride in national origins, and thus paralleled to some extent the history of the northern theme in the national propaganda of the Scandinavian countries and Germany. This has been demon- 


\section{Northern Liberty}

strated recently by Samuel Kliger, whose work furnishes an important supplement to Farley's earlier study, Scandinavian Influences in the English Romantic Movement. ${ }^{13}$ This romance of the North connects with political theory, though the two aspects of the subject are not identical. At first barbaric martial valor is combined with "general Liberty" or "the Seeds of Freedom," the potentiality of developing free institutions. For Thomson the ultimate retreat of Liberty, geographical rather than chronological, is across Switzerland and through the Hanseatic towns-

O'er vast Germania, the ferocious Nurse

Of hardy Men and Hearts affronting Death

To wintry Scandinavia's utmost Bound;

There I the manly Race, the Parent-Hive

Of the mixt Kingdoms, form'd into a State

More regularly free. By keener Air

Their Genius purg'd, and temper'd hard by Frost

Tempest and Toil their Nerves, the Sons of those

Whose only Terror was a bloodless Death,

They wise, and dauntless, still sustain my Cause.

(IV, 364-65, 371-78.)

Thomson's note on "the manly Race" is "The Swedes," who are thus described as keeping to the original pattern of freedom characteristic of the North. In a note on the next to the last line quoted, he gives a cross-reference to a long extract from Temple's essay "Of Heroic Virtue" appended to the following passage in Liberty IV, part of the description of the coming of the Anglo-Saxons:

Pour'd in a fresh invigorating Stream,

With the fierce Race

Blood, where unquelld a mighty Spirit glow'd.

Rash War, and perilous Battle, their Delight;

And immature, and red with glorious Wounds,

Unpeaceful Death their Choice: deriving thence

A Right to feast, and drain immortal Bowls, 
In Odin's Hall; whose blazing Roof resounds The genial Uproar of those Shades, who fall In desperate Fight, or by some brave Attempt; And tho' more polish'd Times the martial Creed Disown, yet still the fearless Habit lives.

(IV, 673-84.)

Temple's text, quoted by Thomson, says that the Goths conceived of a future life in the Hall or Palace of Odin, "where they were entertained at infinite Tables, in perpetual Feasts and Mirth, carousing in Bowls made of the Sculls of their Enemies they had slain." This passage immediately precedes Temple's quotation of the death song of Ragnar Lodbrog, which thereupon became the leitmotif of the Scandinavian revival. ${ }^{14}$ The whole subject has been explored thoroughly, but it may be said that the attention paid to the Scandinavian purple patches has sometimes obscured the central theme of Temple's essay, though careful scholars like Clara Marburg Kirk and Homer Woodbridge have seen the subject in the right perspective. ${ }^{15}$ As Woodbridge says, "Temple distinguishes with reasonable clearness two types of heroic virtue, civic and military." 16 The essay as a whole is dominated by the ideal of the lawgiver and the culturehero rather than by the ideal of the conqueror or warrior. In dealing with the barbarian invasions and the foundations of constitutional government in western Europe, Temple has to present his Scythians as both kinds of hero at once. This duality has been pungently expressed by Sir George M. Trevelyan when he remarks that the Anglo-Saxons were at the same time "bloody-minded pirates" and "Pilgrim Fathers." ${ }^{17}$ But early heroism and the contempt of death are not merely Anglo-Saxon or Scandinavian, but broadly "Gothic." And here we can recognize the importance of a passage in Lucan's Pharsalia which, in connection with the 
song of Ragnar Lodbrog, became the motto of the cult of northern heroism. Lucan attributes the contempt of death to the Gauls, inspired by the wisdom of the Druids, and his lines had been connected with the Scandinavian contempt of death by Aylett Sammes, Thomas Bartholin, and no doubt other writers as well. ${ }^{18}$ Temple, pondering the dual role of the Gothic hero as warrior and legislator, had found in the passage from Lucan an explanation of the wisdom and virtue of the Goths.

Happy in their mistake, those people, whom The northern pole aspects, whom fear of death (The greatest of all human fears) ne'er moves;

From hence their courage prone to rush on steel, Their minds despising death, that think it mean

To spare a life that must again return. ${ }^{19}$

Thomson knew this page of Temple, and furthermore, in the edition of Rapin's History of England which he used he found this passage quoted from Rowe's translation, in connection with the ancient Britons:

Thrice happy they beneath their northern skies,

Who that worst fear, the fear of death, despise;

Hence they no cares for this frail being feel,

But rush undaunted on the pointed steel;

Provoke approaching fate, and bravely scorn

To spare that life which must so soon return. ${ }^{20}$

Thomson's lines on the Britons echo both the Temple and the Rowe versions:

Bold were those Britons, who, the careless Sons

Of Nature, roam'd the Forest-Bounds, at once,

Their verdant City, high-embowering Fane,

And the gay Circle of their woodland Wars:

For by the Druid taught, that Death but shifts

The vital Scene, they that prime Fear despis'd;

And, prone to rush on Steel, disdain'd to spare

An ill-sav'd Life that must again return.

(IV, 626-33.) 
In spite of all that has been written about the famous contempt of death, it has perhaps not been sufficiently emphasized that the heroism thus celebrated is always connected with doctrines of the future life, whether in the form of the delights of Odin's Hall or of Druidic transmigration.

Thomson proceeds to generalize this heroic northern liberty and then to apply it anew to Britain:

Erect from Nature's Hand, by tyrant Force, And still more tyrant Custom, unsubdu'd, Man knows no Master save creating Heaven, Or such as Choice and common Good ordain. This general Sense, with which the Nations I Promiscuous fire, in Britons burn'd intense, Of future Times prophetic.

$$
\text { (IV, 634-40.) }
$$

He tells how Julius Caesar failed to conquer Britain, and how, when the island was taken into the Empire-

The North remain'd untouch'd, where those who scorn'd To stoop retir'd; and, to their keen Effort Yielding at last, recoil'd the Roman Power.

(IV, 647-49.)

The thought of ancient Caledonian freedom was congenial to a Scot, and the result of the dual theme of British and Anglo-Saxon valor was to nationalize the conception of liberty, to center the great northern theme on British history and the British constitution, as the theme might later be centered on American government and history.

Meanwhile, preromantic poets were likely to turn from the political implications to the noble barbarian in his own right and the grandeur of the northern mythology. There was a new sensitiveness to antiquarian imagery, such as the raven-banner of the Danes, which Farley calls "one of the theatrical properties regularly employed by 'runic' poets." ${ }^{21}$ Thomson, as we have seen, dwelt on the contempt of death, 
and though he had but little interest in Norse mythology, he was perhaps the first to catch up the raven-banner and to give it poetic currency. The reference in Rapin runs:

Hubba was slain, and his famous Standard, called Reafan, or the Raven, fell into the hands of the English. The Danes had a Notion, there was a secret virtue in this Standard, which Ivar's Sisters had wrought with their own hands. By the help of a strong fancy, or the delusion of the Devil, they imagin'd they saw this Raven, before a Battle clap his Wings in token of Victory, or hang down his Head, as a presage of their Defeat. $^{22}$

Thomson's comment on the subject in Liberty is drawn directly from this passage: "A famous Danish Standard was called Reafan or Raven. The Danes imagined that, before a Battle, the Raven wrought upon this Standard clap'd its Wings or hung down its Head, in token of Victory or Defeat" (IV, 709 n.). And in a notable passage in Alfred (1740) Thomson elaborated the theme of the weaving of the standard by the sisters of Ivar, who by their "enchanted song" conjure up the "baleful power" of "the Demons of destruction." ${ }_{23}$

But in the long run didacticism leads Thomson to concentrate attention on the national system itself, rather than on the mythical heroes who are supposed to have founded it. This political tradition had a long history before Thomson; Grotius, Puffendorf, Temple, Molesworth, and a whole battery of seventeenth century controversialists handed it on ready made to the eighteenth century, and the popular Huguenot historian Rapin put it into acceptable form for current consumption. Brief statements from Thomson's immediate sources must suffice here. For Temple the system of government by estates, the "mixed government" by king, council, and popular assembly, "seems to have been invented 
or instituted by the sages of the Goths, as a government of freemen, which was the spirit or character of the north-west nations, distinguishing them from those of the South and the East." ${ }^{24}$ Molesworth assumes that "that Natural Love of Liberty, which resided formerly in the Northern Nations more eminently than in other Parts of the World" evolved into the characteristic political institutions of western Europe: "The Ancient Form of Government here [in Denmark] was the same which the Goths and Vandals established in most, if not all Parts of Europe, whither they carried their Conquests, and which in England is retained to this day for the most part." ${ }^{25}$ Thomson makes the transition to constitutional government in the lines immediately following those quoted above on the contempt of death:
Nor were the surly Gifts of War their All.
Wisdom was likewise theirs, indulgent Laws,
The calm Gradations of Art-nursing Peace,
And matchless Orders, the deep Basis still
On which ascends my British Reign. Untam'd
To the refining Subtilties of Slaves,
They brought an happy Government along;
Form'd by that Freedom, which with secret Voice,
Impartial Nature teaches all her Sons,
And which of old thro' the whole Scythian Mass
I strong inspir'd. Monarchical their State,
But prudently confin'd, and mingled wise
Of each harmonious Power: only, too much,
Imperious War into their Rule infus'd,
Prevail'd the General-King, and Chieftain-Thanes.

(IV, 685-99.)

A little later, in connection with a passage already quoted, the mixed government of Britain, King, Lords, and Commons, is evolved with miraculous speed and completeness from "that general Liberty . . thro" the Northern Nations wide diffus'd" (IV, 797-820). For the definite formulation in terms of political theory Thomson no doubt depended on 
Rapin, who in his introductory essay on the English Constitution repeats authoritatively that "the Government of England is a mixt and limited Monarchy, as it is certain all the Governments in Europe establish'd by the northern Nations formerly were." ${ }^{\prime 26}$ For Thomson as for Rapin, the curbing of royal power in the Anglo-Saxon state is important. The chief difference is that Rapin visualizes a continental Germanic model of government without kings, "whereas in England their Chiefs or Leaders took upon them the Title of Kings." The general became the king, but was not invested with absolute power. Thomson, however, going back to the basic conception of barbarous and warlike freedom, speaks of the continental nations founded by the northern swarms in these terms:

Yet, o'er these Gothic States, the King and Chiefs Retain'd the high Prerogative of War.

(IV, 806-07.)

None too clearly, Thomson conceives a potential constitutional model in the northern system which is fully realized for the first time in Britain, and thus he gives the theme of northern liberty a strongly nationalistic turn. 


\section{POLITICAL INTENTIONS}

DOLITICAL journalism found both the classical and I the northern versions of liberty available for both parties. On the level of political theory, the classical model of a "mixed government" and the supposed Gothic model of a limited monarchy were generally admitted to be ideal. Aggressive Whig "Gothicism" persisted in a writer like Molesworth, in his Account of Denmark (1694) and in his translation of Hotoman's Franco-Gallia (1711, 1721), and also in political tracts like Vox Populi, Vox Dei (1709), ${ }^{1}$ but such ideas passed far beyond partisan propaganda. English historiography, notably in Rapin de Thoyras, moved in the same direction. The Whigs captured English history not only in the sense that their version was popular but in the sense that their opponents had to accept it.

While the opposite of "liberty" might naturally be taken to be "tyranny," the actual antithetical term was often "luxury." The great debate on luxury needs to be restudied, and involves major problems in the history of ethical and economic thought; we can take note of it here only as a tool in political controversy. Luxury was the force that had undermined Rome and was now corrupting Britain by establishing false standards that opened the way to bribery and destroyed public spirit.

This is the fruit of Corinth's Luxury,

That nurse of Tyranny! that bane of Virtue!

Where e'er the insinuating Poison spreads,

Our sense it weakens, sinks us into brutes,

It plunges us in Sloth, in Poverty,

In Guilt, Corruption, Slavery, and Ruin. ${ }^{2}$

"Luxury and liberty are incompatible," Mr. Escot long afterwards remarked in Peacock's Headlong Hall. ${ }^{3}$ 
Liberty forces us to consider the polemic against luxury and the praise of ancient freedom and public virtue in terms of the political journalism of the 1730 's. It can hardly be said that one party in this age is for Gothic liberty, the other against it, any more than it can be said that one coherent group opposed or defended luxury. But it came to be the Opposition, the shifting coalition of Tories and dissident Whigs, that stressed the danger to England's ancient heritage and the loss of pristine virtue; and it was the apologists for Walpole who at this point were likely to belittle primordial liberty in comparison with England's gains since $1688 .{ }^{4}$ The question was really somewhat abstruse: How far was the Revolution an innovation, how far a reaffirmation of ancient rights? Whatever Bolingbroke's actual philosophy of history might be-if he can be said to have had one-he presented in the Craftsman, or caused to be presented, a defense of the ancient liberties of Britain against what he described as a corrupt faction; he stepped forth as a champion of the true Whig tradition. In assuming this role, he was following the journalistic lead of John Trenchard in Cato's Letter's and of Wharton in the True Briton. ${ }^{5}$ And this maneuver was connected with the Plutarchan exaltation of public virtue and with the polemic against luxury. These themes were not party properties, but they were used for partisan purposes; the political journalist, like the advertiser, must operate as far as he can with universally acceptable terms. It was thus, as Bateson has recently pointed out, that Pope made virtue "a class-concept, the system of values of the landed interest,' the 'Country Party." "It was thus that Thomson, in the following years, put political allegory "written in benevolist terms" into his dramas. $^{7}$ 


\section{8}

Background of Thomson's Liberty

Though Liberty has always been recognized as an Opposition poem, we do not at present have the detailed record of Thomson's private sentiments and personal relationships which would serve to indicate its exact position or intention. New evidence may yet appear, and any conclusions reached here must be tentative. Thomson's utterances up to 1736 were consistent with the attitudes of important segments of the Opposition, but were so general that they did not in themselves amount to an open commitment. It is hard to say how far he is echoing the sentiments of his influential friends, how far he is candidly stating his own moral and political principles, and how far he is using a partisan device-the conduct of a discussion in acceptable generalities which are suddenly given a special application. The average reader would agree that liberty is a blessing, that the nation lives by public virtue, that luxury is the bane of the age, whereupon he is directly invited to take the next step and to brand Walpole a villain.

Thomson's early dedications, Winter to Sir Spencer Compton (in 1730 created Earl of Wilmington), Summer to Dodington, the Newton lines to Walpole himself, Spring to the Countess of Hertford, Sophonisba to the Queen, Autumn to Speaker Onslow-betoken in themselves nothing more than the personal quest of a patron. All these dedicatees subscribed to the quarto Seasons of 1730 , Dodington taking twenty copies. The most controversial utterance of the early period is Britannia (January 1729), which, as Professor Wells says, "was a notably timely piece, more so for its opportune vigorous voicing of the current hostility to the governmental Spanish policy than for its capitalization of the popular enthusiasm regarding Frederick." ${ }^{\prime 8}$ The poem hails the arrival of Prince Frederick from the Continent in 
December 1728. It was published anonymously and without a dedication, but helpful friends might of course make the authorship known in the right quarter, and the poem was openly acknowledged when it was reprinted in 1730 . Emphatic though Thomson's utterances in Britannia are, he tries to keep them on a patriotic and national level. In the first edition he associates praise of Frederick with praise of the Throne and of "Royal Beauty," despite the fact that the Prince was on bad terms with his father. ${ }^{9}$ This passage was dropped in 1730, though earlier in that year Thomson had dedicated Sophonisba to the Queen. Moreover, Britannia contained a long passage in praise of peace which could be used in favor of Walpole. ${ }^{10}$ The poet's various overtures at this time were tentative. After praise of Britain's seapower and of the flood of business prosperity-the typical preference of Whig panegyric for a pacific commercial imperialism rather than for military conquest-he proceeds to exalt liberty and denounce luxury. The question of how far prosperity could go without exposing the country to the evils of corruption and luxury is not faced, but Thomson's generalities here would be widely acceptable.

The sharply anti-Walpole line which can be detected in Britannia is not immediately followed up. In 1730 Thomson's affinity with the Opposition is not a firm bond, but a slant or bias. It would be natural that he should take political coloring from those whose patronage was continued, and of all his dedicatees Lady Hertford and Dodington seem to have shown most personal interest in the poet in the early 1730 's. It is safe to say that they furthered, though not with marked rapidity, his cordial relations with the Prince. Thomson seems to have been fairly close to Dodington from the time of the publication of Summer in 1727, 
or at least from the time of his visit to Eastbury, Dodington's estate in Dorset, in 1729. From March 1732 the Prince used Dodington as a principal agent, and this relationship would carry Dodington toward open opposition in the course of 1733, but by the end of 1734 he was out of favor. Whatever Dodington may have done, Thomson was glad to approach the Prince through Lady Hertford also, as his letter of October 10,1732, shows; his language seems to imply an early overture, but the details of this episode may best be considered in connection with the actual publication of the poem.

One would also expect the personal relationship with the Talbots to have much weight. The letters of the Reverend Thomas Rundle, the link between Thomson and the Talbots and an ardent promoter of the poet's subscription project, reflect enthusiasm for the Prince's return in December 1728 and also for the work of the Jail Committee in 1729 and $17300^{11}$ Thomson's sentiments are congruous. The first piece of political patronage Thomson received was his appointment as Secretary of the Briefs when Talbot became Lord Chancellor in November 1733. Talbot was one of Walpole's lieutenants, and had actively supported the Excise Bill in that year; a member of his entourage would hardly be in open opposition at this time. In 1734, however, the Lord Chancellor was markedly disaffected because the Crown, at the instigation of Edmund Gibson, Bishop of London, had refused to give Rundle the bishopric of Gloucester, and eventually put him off with the Irish bishopric of Derry. ${ }^{12}$ Accordingly, in 1734 William Talbot, the second and oldest surviving son, declared against Walpole and in 1735 voted against the Government. ${ }^{13}$ In his lines To the Memory of the Right Honourable the Lord Talbot (June, 1737) Thomson 
refers to this political disappointment:

Tho' from native Sun-shine driven,

Driven from your Friends, the Sun-shine of the Soul,

By slanderous Zeal, and Politicks infirm,

Jealous of Worth; yet will you bless your Lot,

Yet will you triumph in your glorious Fate,

Whence Talbot's Friendship glows to future Times,

Intrepid, warm.

(L1. 243-49.)

By the death of Talbot in February 1737 Thomson had lost his sinecure. In August of that year the Prince of Wales, on the recommendation of Lyttelton, gave Thomson a pension of $£ 100$. Thomson's lines to the Prince in the Gentleman's Magazine for September mark his open adherence to the Opposition, and his suggestion that Andrew Millar put these lines into the Craftsman or Common Sense shows how conscious he was of current journalism. ${ }^{14}$ His initiation as a Free Mason, reported in the Daily Advertiser for September 13 , seems clearly to be connected with his adherence to the Prince's faction. Admitted with Thomson was William Hawley, Gentleman Usher to the Prince, as well as Dr. John Armstrong and William Paterson, Thomson's literary friends. Richard Savage, also a follower of the Prince at this time, officiated as Master. Later came Agamemnon, dedicated to the Princess Augusta and produced April 1738, the political prohibition of Edward and Eleonora and its publication in 1739, also with a dedication to the Princess, the production of Alfred before the Prince and Princess at Cliefden in 1740, and the dedication of the Seasons of 1744 and Tancred and Sigismunda in 1745 to the Prince. In short, the favor of the Prince, which had hung fire somehow since 1729 or 1732, was active from 1737 to 1748 , when, because of a falling out between the Prince and Lyttelton, 
Thomson was deprived of his pension and patronage was also withdrawn from Mallet and Gilbert West. ${ }^{15}$

The present study, however, is concerned with Thomson's political attitudes from 1730 to 1736 . What he said about antique virtue, native liberty, public spirit, and the dangers of luxury and corruption was of general application, but was at the same time consistent with the line of opposition journalism, led by the Craftsman, which unfolded Bolingbroke's Old Whig position with endless iteration. "There is really nothing I am so sick of hearing from the lips of our modern Patriots, as the encomiums upon the wisdom of our ancestors and the virtue of the Romans," wrote Walpole's henchman Lord Hervey. ${ }^{16}$ Relying largely on Rapin, the Craftsman's two famous series of papers, the sequence on British history signed "Oldcastle," and the second series called A Dissertation on Parties, took over Old Whig ideas so completely that they forced Government apologists to minimize the early liberties of England in order to exalt the new regime. Thomson had a copy of the 1735 edition of the Dissertation on Parties in his library, ${ }^{17}$ and his familiarity with the whole line of argument is clear.

The notion of the eternal vigilance which is the price of liberty is part of the idiom which Thomson probably drew directly from the Craftsman. Such vigilance is not partisan, but patriotic, and can be sustained only by the high civic virtue found alike in Greece, Rome, and ancient Britain. ${ }^{18}$ The Craftsman's tendentious view of British history may be summed up in the words: "The Principles of the Saxon Commonwealth were therefore very democratical; and these Principles prevailed through all subsequent Changes." In spite of the Norman Conquest and mediaeval tyranny, "all these Disadvantages were supply'd by that 
Spirit of Liberty, which diffused itself through the whole mass." ${ }^{19}$ In his survey of English history in Parts IV and V, Thomson makes large use of Rapin, his indebtedness going considerably beyond the borrowings acknowledged in his notes. Since, as Hervey remarked, Rapin was "the Craftsman's own political Evangelist, ${ }^{20}$ it is only occasionally that we can distinguish sharply between the two influences. Thomson accepts Rapin's view that the Commons were not in Parliament until the thirteenth century, as against the Craftsman's dogma of Anglo-Saxon constitutional democracy, but he follows the account of good and bad monarchs given by the Craftsman; ${ }^{21}$ here he got the elaborate contrast between weak and tyrannous kings like Richard II and great national leaders like Edward III. The contrast was of course pointed at George II..$^{22}$ For the Craftsman and Thomson, Elizabeth is a supreme example of the incarnation of public spirit in the monarch, but both dwell on her extreme use of the royal prerogative, Thomson more emphatically than "Oldcastle." A clear instance of borrowing from the Craftsman rather than from Rapin is found in the account of Henry VII. "His Jealousy, his Pride, and his insatiable, sordid Avarice had their full Swing," says the Craftsman, ${ }^{23}$ and Thomson:

Proud, dark, suspicious, brooding o'er his Gold, As how to fix his Throne he jealous cast His crafty Views around.

(IV, 874-76.)

The importance of the law of Henry VII "opening a Way to the Lords to alienate their Lands" (Craftsman)-"permitting the Barons to alienate their Lands" (Thomson)-is stressed by both, but not mentioned by Rapin. And Thomson's later use of the theme of the liberty-loving King Alfred in the 
94 Background of Thomson's Liberty

famous masque of 1740 is another application of this same view of English history.

As for Thomson's own views, the indications are that his theological inheritance and his concern with the Rundle affair led him at this time to take more interest in the affairs of the Church than was shown by the Craftsman. His personal position in 1735 may be said to approximate that of the Old Whig, or Consistent Protestant, which began publication in March not as an openly anti-ministerial organ but as a representative of Whiggish Dissent. This journal speaks in appreciation of the Craftsman's adoption of Whig principles:

There has been one good Effect of [Bolingbroke's] Writing, that the Tories, who were his former Friends, are come much into the Popular Notions of Liberty; and the old Doctrines, of the Divine Authority of Princes, and of absolute Submission to them, which they consider'd as Sacred, seem now totally discarded by them.

(May 8, 1735.)

The Old Whig likewise sympathized with the libertarian enthusiasm of Shaftesbury (April 10, 1735), supported Rundle against the Weekly Miscellany (May 15), approved Hoadly's Plain Account of the Nature and End of the Sacrament (June 26), and advocated the repeal of the Test Act (January 8, January 22, 1736). We know that Thomson supported Rundle and approved Hoadly's book, ${ }^{24}$ and it seems certain that he must have sided with those who were trying to repeal the Test Act, the younger group known as "the Patriots," who were blocked on this measure by a temporary coalition between the Church Tories and Walpole. ${ }^{25}$ Before the end of 1735 the Old Whig was in controversy with Walpole's organ, the Daily Gazetteer, and in 1736 was praising the Prince of Wales (May 6.) ${ }^{26}$

The general course of politics in 1736 and 1737 seems to 
have accentuated the Opposition sentiments that could be read into Liberty, and even to some extent to have altered the application of the poem. The Dedication to the Prince declares an intention "to trace Liberty, from the first Ages down to her excellent Establishment in Great Britain." But the advertisements of Part IV in January 1736 suggest that liberty is in danger: "The Design of this Poem is to trace the Rise and Fall of Liberty, in the several States wherein she has flourish'd; and an Advice to Britain how to preserve it in this Island." ${ }^{27}$ Our approach to this theme must involve some speculation about the letter of October 10,1732, to Lady Hertford:

Give me leave to return you my most humble acknowledgements for the honour you did me in presenting my Book to the Prince of Wales. I wish it had been something more worthy of you to present, and of him to read. The approbation he was pleased to give a first Imperfect essay does not so much flatter my vanity as my hope, of seeing the fine arts flourish under a Prince of his so noble equal humane and generous dispositions; who knows how to unite the sovreignty of the Prince with the liberty of the People, and to found his happiness and Glory on the publick good oh happy as a God he who has it both in his hand and in his heart to make a people happy!28

"Book" perhaps refers to the Seasons of 1730, with Britannia included in the same volume and here called "a first Imperfect essay"; the words just quoted may thus link the compliment to the Prince in Britannia with the coming Dedication of Liberty, and also with the tribute to the Prince as a potential patron of the arts in the conclusion of Part I, where the Royal Family is praised in these terms:

There Truth, unlicens'd, walks; even Kings themselves

Invite her forth, the Monarchs of the Free!

By that best Glory pierc'd, that God-like Joy,

That gay Security, that Pride of Rule;

When Men, not Slaves, when all-performing Love, 
Not sluggish Hate, and faithless Fear, obey. Fix'd on my Rock, there an Indulgent Race O'er Britons wield the Scepter of the Heart: And, mixing Worth with Worth, the Royal Pair To steady Justice yielding Goodness join. Nor sets the Prospect in this pleasing view; While there, to finish what his Sires began, A Prince behold! for Me who burns sincere, Even with a Subject's Zeal. He my great Work Will Parent-like sustain; and added give The Touch, the Graces and the Muses owe. For Britain's Glory swells his panting Breast; And Antient Arts he emulous revolves: His Pride to let the smiling Heart abroad, Thro' Clouds of Pomp, that but conceal the Man; To please his Pleasure; Bounty his Delight; And all the Soul of Titus dwells in Him.

(1st ed., I, 369-90.)

We know of no immediate reward for these fulsome words, no prompt weighing of solid pudding against empty praise. It is conceivable that the worsening of Dodington's relations with the Prince in 1734 delayed matters. However that may be, such words would be taken to have marked political intent by 1736 . We may note that while the tribute to the Prince was of course retained in 1738, praise of the King had become impossible. The first two lines quoted above are changed to read;

There Truth, unlicens'd, walks; and dares accost Even Kings themselves, the Monarchs of the Free!

Whether the King wants to be accosted by Truth is another matter. The next four lines, in praise of royal magnanimity, are dropped, and also the two lines complimenting the Royal Pair (Caroline died in 1737).

In the first three Parts, the only overt editorializing in the manner of the Opposition is at the end of Part I, when the poet, addressing Liberty, speaks thus of his Muse: 
And when her Venal Voice she barters vile, Or to thy open or thy secret Foes;

May ne'er those sacred Raptures touch her more, By slavish Hearts unfelt! and may her Song Sink in oblivion with the nameless Crew!

Vermin of State! to thy o'er flowing Light

That owe their Being, yet betray thy Cause.

$$
\text { (1st ed., I, 357-63.) }
$$

Five months after Part III had appeared, the Craftsman devoted a leading essay to the poem, beginning by quoting the passage which ends with the seven lines just given. The writer than proceeds to make the political application at length:

It may be said, perhaps, that to complain of the open Prostitution, with which the Cause of Liberty and Virtue hath long been encounter'd, is too stale for the Attention of the Publick; who have experienced that Redress is not to be obtain'd by Complaint.

But the frank Indecency of uniting an abandoned Crew of Scribblers, to exert the Arts of Fraud and Venality, and push them in Defense of ministerial Authority, is so visibly an Attempt to corrupt the Morals, and baffle the common Sense of the Nation, that the Consequence of it concerns every Man, who prefers Virtue to Vice, and Freedom to Slavery.

As the great and virtuous Sentiments, convey'd in the Motto to this Letter, are equally of Use to strengthen the Foundation of Liberty, and to elevate any System of publick Good, that can be rais'd upon it, every servile Pen hath been employ'd, either absurdly to question the Truth, or infamously to weaken the Force, by endeavouring to divert the Influence of them.

The Poem itself, indeed, from whence these Lines are taken, hath pass'd uncensur'd, and the Author unblemish'd; but it seems to be the only Exception to that unlicens'd Abuse, which has been thrown upon every Man, who has express'd his Fear for the Publick, or his Concern for the Welfare of it. So little Decency has been observ'd in This, that the sincerest Friends of the Government have been treated as the Enemies of it, and the warmest as the Destroyers of the Constitution. The Hands prostituted in this 
detestable Service have not discovered less Readiness to engage, than Incapacity to succeed in it; and therefore They are too low to draw any farther Remarks from me. But the destructive Views of Him, who prompts and supports them, creates in a good Mind an honest Indignation, accompanied with such Reflections as ought not to be stifled. ${ }^{29}$

Another long quotation from Liberty (III, 103-52) on public spirit among the Romans is the basis for a discussion of public spirit in general, which must be derived, says the writer, not from cold reason but from overmastering passion. It follows, the editorial application continues, that he who is moved by such a passion will prefer "Independency" and a "private Fortune" to "publick Plunder." The writer thus sums up the doctrine of the earlier parts of the poem, anticipates Thomson's address to Independence in Part V, and openly espouses the work as an Opposition utterance.

The lines by "G. W." (Gilbert West?) in the Gentleman's Magazine for December 1736, "On Mr. Thomson's Picture drawn by Mr. Slaughter, with the Figure of Liberty in his Hand, as describ'd by him in his Poem on that Subject," mark further recognition of the poem as an Opposition document, and indicate that Thomson was openly at odds with the Walpole government even before the death of Talbot:

Yes, Slaughter, in these lines a soul I trace

That scorns a falsehood ev'n to gain a place. ${ }^{30}$

The complacency often attributed to Liberty as a prime example of Whig panegyric cannot be found unmixed in the poem itself. Part V, "The Prospect," speaks of vices and follies that make against virtuous independence-ostentatious building and gardening, operas and masquerades, gambling and servile flattery (1l. 157-99). Despite later references to colonization, philanthropy, the reform of the stage, the advance of the arts (particularly Burlington's architecture and the 
gardening of Pope and Bathurst), the building of toll-free highways, canals, and other public improvements (11. 638716), the poet is not fully assured by these "varied Wonders." When Richard Savage addressed to the Prince in 1737 his poem Public Works-a theme, he remarks, "worthy a Thomson's Muse, a Frederic's Ear"-Thomson's comment on his friend's effort is in a satirical vein:

$\mathrm{He}$ has lately published a fine poem on Public Works; a very impudent subject for one to write upon at this time $o$ day. When his annual fifty is turned into a thousand pounds, then will he see certain grounds like the sylvan scenes he describes. He will be driven in his coach and six, when he sees noble public roads without, even with, turnpikes. When he sees a senate uncorrupted, he will see a magnificent senate-house; and when a court becomes the patron of arts, another Whitehall. He will see a play-house such as he recommends, when a chamberlain shall be the proper judge of plays, and when slavery more exalts the genius than liberty. When he has begot bastards enow to fill an hospital for foundlings, he will see one; and when he sees bridges, worthy of the Thames, he will have faith enough to walk the waters. He will have a government assigned him, when we send out generous and perfectly free colonies; and when he sees West Indian slaves treated so as not to shock common humanity, he may wash them white.-This he may print for a puff to his next edition. ${ }^{31}$

The rather complex humor of this passage, even allowing for a free and facetious vein in private, does not indicate an uncritical acceptance of things as they are.

The most enthusiastic contemporary tribute, Samuel Boyse's lines "Written in Mr. Thomson's Essays on Liberty," likewise emphasizes the theme of liberty in danger:

When Liberty celestial Goddess saw

Thomson's bold Hand her matchless Beauties draw;

Pleas'd, as the Work intently she survey'd,

How bright the Colours! and how strong the Shade!

Fondly she cry'd-"In this immortal Page,

My Charms shall bloom untouch'd to latest Age; 


\section{Background of Thomson's Liberty}

Tho Britain should like Rome of old divide,

And sink the Prey of Luxury and Pride!

Tho' every Heart the Love of me should lose,

Here shall they learn the Blessings they refuse!

Tho' from this fav'rite Isle, my last Retreat!

Constrain'd I should be forc'd-and with Regret:

Tho' Servitude should overwhelm the Ball,

Here I shall live!-and sigh to see the Fall! $!^{31 a}$

The failure of Liberty to win favor in its own day or at any other time is primarily an artistic failure. Thomson's blank-verse style cannot cope with abstract ideas taken over en bloc. He could, we may say, write highly generalized verse with success when his imagination worked from a fully visualized situation; but a systematic expository project made his blank verse harsh and labored, full of awkward inversions and choppy antitheses that strive for unwarranted emphasis and intensity. Isaac Hawkins Browne immediately chose Liberty as one of the objects of his burlesque in A Pipe of Tobacco. $^{32}$ Aaron Hill's comments strike us as outrageous flattery, though it is worth noting that he regards the poem as a lament for the times rather than as an outburst of patriotic pride:

I don't know a pleasure I should enjoy with more pride, than that of filling up the leisure of a well-employed year, in exerting the critic, on your poem; in considering it, first, with a view to the vastness of its conception, in the general plan; secondly, to the grandeur, the depth, the unleaning, self-supported richness of the sentiments; and, thirdly, to the strength, the elegance, the musick, the comprehensive, living energy, and close propriety of your expression. I look upon this mighty work, as the last stretched blaze of our expiring genius. It is the dying effort of despairing and indignant virtue, and will stand, like one of those immortal pyramids, which carry their magnificence thro' times, that wonder, to see nothing round them, but uncomfortable desart! ${ }^{33}$

But even Hill found fault with the style. On reading Part I he had written: 


\section{Political Intentions}

Never was there expression more strongly easy, more clearly illustrative, than in every one of [your poems], except this last: How happens it, that you would change a grace, almost peculiar to yourself, in favour of transposition and obscurity, by endeavoring after beauties, which, I am sure, are unnecessary to your poem, and (I fear) unnatural to our idiom. ${ }^{34}$

Thomson's friend and biographer, Patrick Murdoch, simply asserted the connection between the loftiness of the theme and Thomson's own esteem for Liberty: "He employed two years of his life in composing that noble work: upon which, conscious of the importance and dignity of the subject, he valued himself more than upon all his other writings." ${ }^{.35} \mathrm{John}$ son echoes these words of Murdoch's in commenting on the fate of the poem: "Upon this great poem two years were spent, and the author congratulated himself upon it as his noblest work; but an author and his reader are not always of a mind." ${ }^{36}$ Mrs. Catherine Macaulay had quoted Thomson's invocation to Liberty at the beginning of her History of England. ${ }^{37}$ "Sir, there is one Mrs. Macaulay in this town, a great republican." Johnson's condemnation of Liberty was determined not only by his dislike for contorted blank verse but by his aversion to the dogmas of classical republicanism. $\mathrm{He}$ opens his discussion of the poem by remarking, "At this time a long course of opposition to Sir Robert Walpole had filled the nation with clamours for liberty, of which no man felt the want, and with care for liberty, which was not in danger." Though he had himself been in opposition, he could not look back with approval on the maneuvers of the Craftsman. In Lyttelton's Letters from a Persian in England he notes "something of that indistinct and headstrong ardour for liberty which a man of genius always catches when he enters the world, and always suffers to cool as he passes forward." ${ }^{38}$ His comments on Gray's Progress of Poesy also help to make his attitude clear: 


\section{Background of Thomson's Liberty}

His position is at last false: in the time of Dante and Petrarch, from whom he derives our first school of Poetry, Italy was over-run by tyrant power and coward vice; nor was our state much better when we first borrowed the Italian arts. $^{39}$

What Johnson refrains from saying categorically in his comments about Liberty itself, he says in his hostile review of Thomas Blackwell's Memoirs of the Court of Augustus. Blackwell, like his fellow Aberdonian George Turnbull, was an admirer of Liberty, and in his libertarian survey of Roman history uses ideas and lines from the poem. ${ }^{40}$ Johnson thereupon gives the book what Saintsbury would call an "éreintement" or "slating." "I know not, why any one but a schoolboy, in his declamation, should whine over the commonwealth of Rome, which grew great only by the misery of the rest of mankind." "Among other affectations of this writer, is a furious and unnecessary zeal for liberty." "He is come too late into the world with his fury for freedom, with his Brutus and Cassius." ${ }^{11}$ In a cooler tone, Goldsmith expresses essentially similar views of the Craftsman's journalistic campaign:

A calm disinterested reader, is now surprised at the heat with which many subjects at that time, of little importance in themselves, were discussed. He now smiles at these denunciations of slavery and of ruin, which were entailed upon posterity, and which posterity did not feel. ${ }^{42}$

Later the enthusiastic Lord Buchan, combining admiration for Thomson with ardor for the French Revolution, declared indignantly that Johnson's verdict on the poem was purely the result of political prejudice. ${ }^{43}$ His sentiments were echoed in a novel of the following year:

Mr. Hungerford observed, that he had lately been perusing Thomson's poem on Liberty, of which a celebrated writer remarks, that when it first appeared, he tried to read it, 
and soon desisted, and never tried again. 'Now,' said Mr. Hungerford, 'I found no difficulty in going to the end of it; on the contrary, I read the whole of it with a great deal of satisfaction.' 'The writer of whom you speak,' said Waldegrave, 'was influenced in his opinion of that work by his political prejudices. He did not like the subject of Thomson's poem. I have repeatedly read his poem on Liberty with great pleasure, as well as his inimitable Seasons, and his admirable Castle of Indolence. Indeed, Thomson has ever been a favorite poet of mine. He paints from nature, and his works are strongly characterized by original and inventive genius." 44

But good words for Liberty have seldom been part of the generous praise long accorded to Thomson. And rarely does the poem seem to have influenced later writers, though Margaret Lowery has demonstrated its influence on the youthful Blake. ${ }^{45}$ Francis James Child's comment is depressing but no doubt accurate-“a composition which has been seldom perused save by editors and proofreaders." ${ }^{\text {(66 }}$

In conclusion, it remains to note briefly the connection between the political intentions of the poem and its view of cultural history. It must appear, I think, that as a sweeping synthesis or elaborate piece of syncretism the work is typical of its age. The popular thought of the eighteenth century did not welcome profound metaphysical views, but it was eager for synopses and rapid surveys. It was willing to be confronted with a prospect in good set terms:

Let Observation, with extensive view,

Survey mankind from China to Peru.

Liberty is a "China to Peru" performance, based on oversimplified conceptions of "Reason," "Freedom," and "Public Virtue," which play the same part here that "Nature all-sufficient" does in The Seasons. Perhaps the true function of such generalities is to promote the rendering of significant images and incidents such as we get in the best poetry and fiction 


\section{Background of Thomson's Liberty}

of the period. By this standard Liberty fails; it is a foundation not built upon, a program unexecuted. Collins's Ode to Liberty, following Thomson's poem and building upon it, is by comparison much more successful. ${ }^{47}$ Yet, though Liberty is over-ambitious and abortive, it is in a sense central and representative.

Personal and special views and first-hand experience are subordinated or suppressed as Thomson tries to develop generally acceptable ideas which turn out not to be entirely consistent with one another. The liberalism and the mode of Whig panegyric which mark the poem are too inclusive to attach the work closely to a sect or school. Thomson is hospitable to conceptions of ancient freedom, of northern liberty, of generalized nobility and intense feeling in works of art. Professor Kliger's able studies have emphasized the theme of Gothic liberty in the poem. Continuing his discussion without exclusive reference to Liberty, he also suggests that the increasing favor with which Gothic styles were viewed in the arts is connected with British freedom (comedy of humors, blank verse, emancipation from rules, English gardening) and falls under the general caption "Whig aesthetics." ${ }^{48}$ As a comprehensive account, this ingenious synthesis probably stakes too much on the protean term "Gothic." Liberty admits political "Gothicism" (though it does not use the "Gothic" label) only so far as it is conceived to be consistent with classical republicanism; its pattern falls in with the Roman idiom of late eighteenth century politics, would find a place somewhere near Cato in the cultural history of the time, and would thus connect with the cultivation of classical styles in architecture, interior decoration, sculpture, ceramics, and other fields. Perhaps there may be some positive value in the conclusion that though Liberty obvi- 


\section{Political Intentions $\quad 105$}

ously deserves the label "Whig" rather than the label "Tory," so that Mrs. Macaulay and Lord Buchan could approve and Johnson and Goldsmith disapprove, it cannot be fully described in terms of a direct opposition of radical to conservative or romantic to classical (let alone primitivism versus progress, simplicity versus luxury, or classical antiquity versus the Middle Ages), but, following a vague impulsion derived from the thought of the times, seeks to evade revolution and extremism in terms of some vaguely conceived ideal of inclusion and harmony. 


\section{NOTES}

When no place of publication is given in references to books, London is understood. Liberty is quoted from the text in Thomson's Works, 1738, Vol. II. The most accessible modern reprinting, J. Logie Robertson's in the Oxford Edition, 1908, is based on this text. Linenumbers in these two editions correspond closely, though not always exactly, and cross-reference can easily be made. Quotations from The Seasons are, except for references to later revisions, from the continuously paged octavo of 1730; this edition has been chosen because it is chronologically closest to the period when Thomson was writing and publishing Liberty.

The following abbreviated references are used:

Background of Seasons Alan D. McKillop, The Background of

Liberty

Morel

Rundle

Sale Catalogue

Seasons (Spring, Summer, etc.)

Sherburn Festschrift
Thomson's 'Seasons,' Minneapolis, 1942.

Revised text in James Thomson, Works, 1738, Vol. II.

Léon Morel, James Thomson: sa vie et ses oeuvres, Paris, 1895.

Letters of the Late Thomas Rundle, 2 vols., Gloucester, 1789.

A Catalogue of all the Genuine Houshold Furniture . . b d c. of Mr. James Thomson ... together with His compleat Library of Books [1749].

Continuously paged octavo of 1730 .

Pope and His Contemporaries: Essays Presented to George Sherburn, ed. James L. Clifford and Louis Landa, Oxford, 1949.

The following standard abbreviations are also used: $C B E L-$ Cambridge Bibliography of English Literature, MLN-Modern Language Notes, MLQ-Modern Language Quarterly, MP-Modern Philology, NdQ-Notes and Queries, PMLA-Publications of the Modern Language Association, PQ-Philological Quarterly, SPStudies in Philology, TLS-(London) Times Literary Supplement.

I.

1. See Alan D. McKillop, "The Early History of Thomson's Liberty," $M L Q$, XI (1950), 307-16. To the details of publication here given should be added Professor Douglas Grant's discovery of an attempted Edinburgh piracy of Part I (James Thomson: Poet of 
'The Seasons' [1951], p. 147, quoting Daily Post-Boy, February 24, 1733-34 [i.e., 1734-35?]).

2. See Alan D. McKillop, "Ethics and Political History in Thomson's Liberty," Sherburn Festschrift, pp. 215-29.

3. For interesting comments on the Grand Tour and Scottish tutors, see Samuel Richardson, Pamela (Shakespeare Head Edition; Oxford, 1929), IV, 323-27. Thomson was engaged "only as a companion" with an allowance of $£ 200$ a year (Grant, op. cit., p. 95).

4. Historical MSS Commission. Various Collections, VI (1909), 10. Thomson to Dodington, November 28, 1731. In connection with Thomson's travels, it should be noted that his letter to Dodington, October 24, 1730, is taken to be written from Paris in 1731 by Morel, pp. 94-95, and on this point Morel is followed by several later biographers. But the letter is dated 1730 in Seward's Supplement to the Anecdotes of Some Distinguished Persons (1797), p. 140, where it first appeared, and also in the report of the Historical MSS Commission, Various Collections, VI, 7-8. Moreover, in the full text printed in the latter source Thomson says he is leaving for Paris in about two weeks. This misdating has made it appear that Thomson and Talbot stayed in Paris, or at least in France, from the end of 1730 to October 1731, and then hurried on to Rome, whereas in reality they must have spent a good part of 1731 in extensive travel in France and Italy. Joseph Spence, traveling with Lord Middlesex, met Thomson and Talbot at Lyons "in the summer of $1731 \ldots$ and apparently again at Venice in the autumn" (Austin Wright, Joseph Spence [Chicago, 1950], p. 39). The idea of a ten-month sojourn in Paris is erroneous, and, as suggested above, it seems improbable that the travelers hastened home in December 1731.

5. Rundle, II, 181.

6. Helen Sard Hughes, "Thomson and the Countess of Hertford," $M P, \mathrm{XXV}$ (1928), 454-57.

7. The Trinket (1774), pp. 159-60.

8. A Collection of Letters Written to the Late Aaron Hill (1751), pp. 56-57. To Hill, April 18, 1726. Dr. Orville F. Linck rightly emphasizes the importance of benevolist doctrines for Thomson's work, and makes justifiable claims for the influence of Hutcheson's psychology and ethics ("Benevolism in the Works of James Thomson," Northwestern University Summaries of Doctoral Dissertations . . 1941 [Chicago, 1942], pp. 23-28). These passages of 1726 , however, are probably too early to be called Hutchesonian.

9. See Alan D. McKillop, "Thomson and the Jail Committee," SP, XLVII (1950), 62-71. 


\section{Background of Thomson's Liberty}

10. See John Edwin Wells, "Thomson's Britannia," MP, XL (1942), 43-56, especially $47-48$.

11. See p. 21.

12. Samuel Boyse, Translations and Poems Written on several Subjects (Edinburgh, 1731), pp. 124-26. These lines were published, perhaps for the first time, in The Eccho: or, Edinburgh Weekly Journal, April 15, 1730, with a somewhat different text.

13. W. J. Courthope, History of English Poetry (1911), V, chap. ii; Cecil A. Moore, "Whig Panegyric Verse, 1700-1760: a Phase of Sentimentalism," PMLA, XLI (1926), 362-401.

14. Bonamy Dobrée, "The Theme of Patriotism in the Poetry of the Early Eighteenth Century," repr. from Proceedings of the British Academy, XXXV (1949).

II.

1. Characteristicks (1737), III, 151-52.

2. Life, Unpublished Letters, and Philosophical Regimen, ed. Benjamin Rand (1900), p. 449.

3. Characteristicks, II, 252.

4. Ibid., III, 312-13.

5. William Wotton, Reflections upon Ancient and Modern Learning (2nd edition, 1697), pp. 36-37.

6. Characteristicks, I, 238-39.

7. Ibid., I, 222-23.

8. Ibid., I, 219-20, 222, $269 \mathrm{n}$.

9. Ibid., I, 218.

10. Historical MSS Commission. Downshire MSS, I, ii (1924), 777, 782-83.

11. Mrs. Susannah Centlivre, The Wonder: A Woman Keeps a Secret (1714), I, i; Dramatic Works (1872), III, 8. Quoted by Clement Ramsland, "Britons Never Will Be Slaves," Quarterly Journal of Speech, XXVIII (1942), 397. This article quotes many passages in praise of liberty from English plays, 1700-1742.

12. Robert, Viscount Molesworth, An Account of Denmark (1694), sig. c7. Sale Catalogue, No. 49. Thomson quotes Molesworth in his note to Liberty, V, 285.

13. Letter of October 16, 1729, quoted by Rose Mary Davis, The Good Lord Lyttelton (Bethleham, 1939), pp. 24-25.

14. George, Lord Lyttelton, Poetical Works (1801), pp. 39-40.

15. Ibid., p. 51.

16. Historical MSS Commission. Various Collections, VI (1909), 8.

17. William Seward, Supplement to the Anecdotes of Some Distinguished Persons (1797), pp. 139-40. Letter of December 27, 1730.

18. Rundle, II, 164. 
19. Historical MSS Commission. Various Collections, VI, 10-11.

20. The Lives of the Most Eminent English Poets (1783), IV, 253.

21. G. C. Macaulay, James Thomson (1908), p. 35.

22. Helen Sard Hughes, "Thomson and the Countess of Hertford," $M P, \mathrm{XXV}$ (1928), 455-56. For some corrections in the transcription of Thomson's letter I am indebted to Professor Ralph M. Williams.

23. See Background of Seasons, pp. 2-3; Morel, p. 104.

III.

1. Remarks on Several Parts of Italy (2nd edition, 1718), unsigned leaf before sig. al. References below are to this edition.

2. It seems probable that Thomson had access to Harris's collection when he was writing Liberty, though he may also have known separate editions of Lassels, Ray, and Misson, For use of Harris in the original versions of Summer (1727) and Spring (1728), see Horace E. Hamilton, “James Thomson's Seasons: Shifts in the Treatment of Popular Subject Matter," ELH, XV (1948), 114-16; for use of Harris in later revisions of The Seasons, see Hamilton, loc. cit., and his "Note' on James Thomson's Sources,” MLN, LXIII (1948), 46-48; also Background of Seasons, pp. 139-40, 159.

3. Sale Catalogue, No. 216.

4. Misson (4th edition, 1714), II, 106; Harris, II, 679.

5. Lassels (1670), II, 267-68; Harris, II, 628.

6. George Sandys, Travels (7th edition, 1673), pp. 216-17; Misson, I, 442-43; Montfaucon, pp. 377-78. In 1740 Gray sent to Richard West a Latin poem on the subject, based on Sandys-Correspondence, ed. Toynbee and Whibley (Oxford, 1935), I, 175-77.

7. On the last line quoted Thomson has another note which takes us farther afield: "According to Dr. Burnet's System of the Deluge." For details on Thomson's use of Thomas Burnet's Telluris Theoria Sacra, see Background of Seasons, pp. 97-104.

8. Gilbert Burnet, Travels, Or Letters Containing An Account of what Seemed most Remarkable in Switzerland, Italy, France, and Germany, \&c. (Amsterdam, 1687), Letter III, p. 103. References below are to this edition. For the description of the Ligurian coast, cf. also Three Letters Concerning the Present State of Italy ... Being a Supplement to Dr. Burnet's Letters (n.p., 1688), p. 168.

9. Lassels, I, 83; Harris, II, 603.

10. Lassels, I, 92; Harris, loc. cit. Cf. also Three Letters Concerning the Present State of Italy, p. 173.

11. For an excellent survey of the place of Venice in political theory, see Zera S. Fink, The Classical Republicans (Evanston, 1945), passim, but especially chap. 2 . 


\section{Background of Thomson's Liberty}

12. Ray (1673), p. 150; Harris, II, 560.

13. Ray, p. 154; Harris, II, 561.

14. Quoted by Misson, I, 459. There is a translation in the London Magazine, II (1733), 34. "Sannazarius's Epigram is too well known to be inserted," says Addison (p. 81), but he quotes other verses by Sannazaro in praise of the magnificence of Venice and her association with Roman freedom.

15. Fink, op. cit., pp. 176-77.

16. See Elizabeth Wheeler Manwaring, Italian Landscape in Eighteenth Century England (New York, 1925), pp. 105-06; Background of Seasons, pp. 74-75; MLQ, XI (1950), 315-16.

17. Essays and Letters on Various Subjects (1739), p. 208.

18. Travels, Letter IV, p. 2. This passage was evidently a favorite with political journalists writing in praise of liberty. It is quoted by Thomas Gordon in Cato's Letters, No. 68, March 3, 1721, repr. 1733, II, 326-27; and also in the Old Whig, May 15, 1735.

19. Letter IV, pp. 9-10.

20. Roderick Marshall, Italy in English Literature 1755-1815 (New York, 1934), p. 12.

21. To Goldsmith's use of the theme of the ruin of Rome by luxury, rightly emphasized by H. J. Bell ("The Deserted Village and Goldsmith's Social Doctrines," PMLA, LIX [1944], 747-72), may be added his use of the traditional traveler's view of Italy, and its partial transfer and application to the English scene.

IV.

1. See R. D. Havens, "Primitivism and the Idea of Progress in Thomson," SP, XXIX (1932), 41-52; Background of Seasons, chap. iii.

2. Franklin, in his "Idea of the English School," would have young students begin ancient history with Rollin-Writings, ed. A. H. Smith (New York, 1907), III, 25.

3. Rollin, Histoire ancienne (Paris, 1740), I, 58-59. References are hereafter to this edition. French spellings have been modernized.

4. Ibid., I, 57.

5. Ibid., I, 23.

6. Thomson, Works (1750), II, 53.

7. Rollin, I, 114-15; Ezekiel xxix; 3, 9.

8. Plutarch, Lives (1727), I, 196. References are hereafter to this edition.

9. Zera S. Fink, The Classical Republicans (Evanston, 1945), pp. 4-6, 9.

10. Plutarch, I, 247-48.

11. Histoire ancienne, IV, 448-49.

12. Ibid., II, 573-74.

13. Ibid., IV, 303-05.

14. Characteristicks (1737), I, 253-54. 
15. See Background of Seasons, p. 124.

16. Plutarch, III, 8.

17. Histoire ancienne, III, 417.

18. Ibid., III, 222.

19. Ibid., VII, 115-16.

20. Ibid., III, 499.

21. Ibid., II, 488.

22. See Background of Seasons, pp. 35-36.

23. See below, chap. v.

24. Horace, Odes, III, v; Rollin, Histoire ancienne, I, 336. Cf. William Havard's play Regulus (1744), and Benjamin West's painting in Kensington Palace, reproduced in Johnson's England, ed. A. S. Turberville (Oxford, 1933), II, opposite p. 58.

25. Plutarch, III, 435.

26. Rollin, Method of Teaching and Studying the Belles Lettres (3rd edition, 1742), IV, 30-31, 98. In the series of essays "On the Study of the Belles Lettres" published in the British Magazine (1761-63) and erroneously attributed to Goldsmith, the Flaminius passage in Liberty is highly praised. See Goldsmith, Works, ed. J. W. M. Gibbs (Bohn Library), I, 332, and R. S. Crane, CBEL, II, 640.

27. For a good general survey of the subject, see Walter Rehm, Der Untergang Roms im abendländischen Denken (Leipzig, 1930).

28. Histoire des révolutions arrivées dans le gouvernement de la république romaine (Paris, 1719). Sale Catalogue, No. 30 , records "Vertot's Revolutions of Rome, 1740," but, as in some other instances where a late edition appears in this list, Thomson's earlier use of the work is evident.

29. Cf. Cato's Letters, No. 18, February 25, 1720, repr. 1733, I, 11821; Craftsman, No. 493, December 13, 1735.

30. History of the Revolutions that Happened in the Roman Republic (4th edition, 1732), I, sigs. B2-B3. References hereafter are to this edition.

31. Cf. Spring, 11. 52-66.

32. Odes, IV, iv. Churton Collins notes this parallel, Ephemera Critica (1902), pp. 324-25.

33. Plutarch, IV, 275-76.

34. Vertot, II, 190-91.

35. Ibid., II, 192.

36. Ibid., II, 257-58.

V.

1. For the extensive influence of Dufresnoy in England, see John W. Draper, William Mason (New York, 1924), pp. 308-13, and references there given. See also W. K. Wimsatt, Jr., "Johnson and Dryden's Du Fresnoy," SP, XLVIII (1951), 26-39. 


\section{Background of Thomson's Liberty}

2. Charles Lamotte, An Essay upon Poetry and Painting (Dublin, 1742), p. 14.

3. Edward Wright, Some Observations Made in Travelling through France, Italy, \&c. (1730), p. 349.

4. Du Bos, Réflexions critiques sur la poésie et sur la peinture (Paris, 1733), II, 195-98.

5. Jonathan Richardson, An Account of the Statues, Bas-reliefs, Drawings and Pictures in Italy, France, etc. (2nd edition, 1754), p. 156. First published 1722 .

6. André Félibien, Entretiens (1705), IV, 76.

7. George Turnbull, Treatise on Ancient Painting (1740), p. 166.

8. Stephen A. Larrabee, English Bards and Grecian Marbles (New York, 1943), pp. 79, $82 \mathrm{n}$. The list of "Antique Drawings" in the Sale Catalogue was reported by Robert Carruthers, $N \downarrow Q$, S. 1, XI (1855), 202. See also Morel, p. 113.

9. See Margarete Bieber, Laocoon, the Influence of the Group since its Rediscovery (New York, 1942).

10. Pliny, Natural History, xxxv, 64, 79, 91, 104-05; K. Jex-Blake, The Elder Pliny's Chapters on the History of Art (1896), pp. 109, 127-29, 137-39; Félibien, Entretiens, I, 60. It may be added that Aglionby's Painting Illustrated in Three Diallogues (1685), pp. 54-55, takes the Protogenes anecdote from Félibien, and is verbally close to Thomson. Thomson had this edition of Aglionby.

11. Roger de Piles, Conversations sur la connoissance de la peinture (Paris, 1677), p. 243.

12. Félibien, Entretiens, II, 212-13.

13. Samuel Rocheblave, "L'Art français au xvii" siècle dans ses rapports avec la littérature," in Histoire de la langue et de la littérature française, ed. Petit de Julleville (Paris, 1908), V, 660721 , especially 689-90.

14. Hubert Gillot, La querelle des anciens et des modernes en France (Paris, 1914), pp. 454-68, states this opposition with some exaggeration, that is, without allowing for the mediating influence of such a critic as De Piles.

15. Rensselaer W. Lee, "Ut Pictura Poesis: The Humanistic Theory of Painting," Art Bulletin, XXII (1940), 211.

16. Félibien, Entretiens, IV, 23.

17. Rocheblave, loc. cit.

18. Roger de Piles, Abrégé de la vie des peintres (Paris, 1715), p. 541.

19. Ibid., p. 543.

20. Dryden, Poems, ed. John Sergeaunt (1929), p. 168. First published in Miscellanies (1694).

21. Félibien, Entretiens, II, 231.

22. C. A. Dufresnoy, The Art of Painting, trans. Dryden (2nd edition, $1716)$, p. 77 . Cf. also p. 233, and the appended "Short Ac- 
count of the Most Eminent Painters," by Richard Graham, p. 333.

23. Jonathan Richardson, "Theory of Painting," in Works (1792), p. 68.

24. Dufresnoy, trans. Dryden (1716), pp. 47, 137.

25. Ibid., pp. 168, 53-55, 188-89.

26. See Elizabeth Wheeler Manwaring, Italian Landscape in Eighteenth Century England (New York, 1925), pp. 105-06; MLQ, XI (1950), 316.

27. Félibien, Entretiens, IV, 142.

28. [John Elsum], Epigrams upon the Paintings of the Most Eminent Masters, Antient and Modern (1700), p. 20.

29. Jonathan Richardson, Account of the Statues and Bas-reliefs (1722), quoted by Isabel Urban Chase, Horace Walpole, Gardenist (Princeton, 1943), pp. 120-21.

30. Among the subscribers were Thomson, Dr. John Armstrong, Stephen Slaughter the painter, and Thomas Rundle, Bishop of Derry. The general theme of the book is a Shaftesburian program of education. Sophonisba and Liberty are praised (pp. $115,183)$.

31. Ibid., pp. 164, 169.

\section{VI.}

1. Samuel Kliger, "Sir William Temple and the Gothic Cult of the Seventeenth Century," Northwestern University Summaries of Doctoral Dissertations . . 1942 (Chicago, 1943), pp. 25-29; "The Goths in England," MP, XLIII (1945), 107-17; "The Gothic Revival and the German Translatio," ibid., XLV (1947), 73-103. See also Erwin Höltzle, Die Idee einer altgermanischen Freiheit vor Montesquieu (Munich and Berlin, 1925).

2. Arnold J. Toynbee, A Study of History (1934), II, 30.

3. Thomas Blackwell, An Enquiry into the Life and Writings of Homer (1735), p. 64.

4. Ibid., p. 218.

5. Pharsalia, trans. Rowe, VII, 637-40; in Latin text, VII, 433-36.

6. The Loss of Liberty (1733, first published 1729), pp. 23-24.

7. For the personal relations of Thomson and Paterson, see Morel, p. $134 \mathrm{ff}$. It may be added that the two men were admitted Free Masons at the same time (Daily Advertiser, September 13, 1737).

8. Background of Seasons, p. 113.

9. Thor J. Beck, Northern Antiquities in French Learning and Literature 1755-1855 (New York, 1934), I, $19 \mathrm{ff}$. The echo of the vagina gentium theme in Milton (Paradise Lost, I, 351-55) would of course be known to Thomson. 


\section{Background of Thomson's Liberty}

10. Beck, I, 33-34.

11. [Carl Johann von Blomberg], An Account of Livonia (1701), pp. 2-4, 19. Sale Catalogue, No. 52.

12. Beck, I, 45.

13. Frank E. Farley, Scandinavian Influences in the English Romantic Movement (Boston, 1903). Harvard Studies and Notes in Philology and Literature, IX.

14. Ibid., pp. 59-76.

15. Clara Marburg [Kirk], Sir William Temple, a Seventeenth Century 'Libertin,' (New Haven, 1932); Homer Woodbridge, Sir William Temple (New York, 1940), chap. xxi.

16. Woodbridge, p. 276.

17. G. M. Trevelyan, History of England (1929), p. 35.

18. Lucan, Pharsalia, I, 458-62. The passage was current in discussions of northern antiquities: it is quoted twice by Thomas Bartholin, Antiquitatum Danicarum de Causis Contemptae Mortis Libri Tres (Copenhagen, 1689), pp. 4, 315-16, and by Aylett Sammes, Britannia Antiqua Illustrata (1676), p. 461.

19. Temple, Works (1757), III, 352.

20. Rowe's translation, I, 806-11, quoted in Rapin, History of England trans. Tindal (2nd edition, 1732), I, v n.

21. Farley, p. 103 n.

22. Rapin, trans. Tindal (2nd edition, 1732), I, 92.

23. Alfred (1740), pp. 37-38; Act II, Scene iv. "The Raven claps her sable Wings" also in a "Danish ode" printed in The Polite Correspondence (1741), p. 294, for which see Alan D. McKillop, "A Critic of 1741 on Early Poetry," SP, XXX (1933), 515-19. Farley does not note these early references; the "Danish ode" was later erroneously attributed to Michael Bruce. To Farley's references add also John Brown, Athelstan (1756), p. 4; Thomas Maurice, Netherby (Oxford, 1776), pp. 10-11.

24. Temple, Works (1757), III, 366.

25. Molesworth, Account of Denmark (1694), pp. 264, 42.

26. Rapin, trans. Tindal (1726), I, i ff.

VII.

1. Vox Populi, Vox Dei (1709), later entitled The Judgment of Whole Kingdoms and Nations. Sometimes attributed to Defoe, but not his, according to John Robert Moore.

2. John Tracy, Periander (1731), quoted from Beauties of the English Drama (1777), III, 30.

3. Thomas Love Peacock, Headlong Hall (1816), chap. vii.

4. See Sherburn Festschrift, pp. 224-25.

5. Ibid., p. 218; William M. Sale, Jr., Samuel Richardson, Master Printer (Ithaca, 1950), pp. 37-38. 
6. Pope, Epistles to Several Persons (Moral Essays), ed. Bateson (1951), p. xxxix.

7. Orville F. Linck, "Benevolism in the Works of James Thomson," Northwestern University Summaries of Doctoral Dissertations ... 1941 (Chicago, 1942), p. 27.

8. John Edwin Wells, "Thomson's Britannia," MP, XL (1942), 54.

9. Ibid., p. 52.

10. The Daily Journal, January 28,1729 , immediately quoted these lines with this introductory comment:

The following Lines are so charming a Description of the Blessings of Peace, that I am persuaded your Readers will be exceedingly delighted with it, and find Occasions from it to extol and applaud the Pacific Measures that have hitherto been pursu'd by his Majesty and his Ministers, to preserve us those invaluable Blessings; whatever Event their wise Endeavours may be attended with, from the Perverseness and Ambition of some of the Powers of Europe. I have borrow'd them from a Poem just publish'd, intitled Britannia, which, tho' it seems to be written with another View, and even to rouze to War the British Nation, yet the happy Author, who has deprived us of the Pleasure of knowing his Name, has not been able to resist those Charming Impulses which give so just a Preference to those Divine Men, as he aptly calls 'em, who study to cultivate the Arts of Peace.

For the Daily Journal's pro-Walpole tendencies at this time, see Sale, op. cit., pp. 54, 58. The Tory Fog's Weekly Journal, February 1, commenting on the Daily Journal's performance, quoted 81 lines from Britannia on the other side. Eustace Budgell later made similar use of the same passage, quoting at length and with admiration (A Letter to Cleomenes King of Sparta [1731], pp. 52-56).

11. Rundle, II, 46, 68-75. See also McKillop, "Thomson and the Jail Committee," SP, XLVII (1950), 66 and n.

12. Earl of Egmont, Diary (1920-23), II, 137, 151; John, Lord Hervey, Memoirs of the Reign of George the Second (1848), I, 447-55.

13. Rundle, II, 237-50; Egmont, op. cit., II, 154.

14. Gentleman's Magazine, VII (1737), 569; Thomson to Andrew Millar, September 18, 1737, in Background of Seasons, p. 180.

15. Morel, p. 164; A. S. Collins, Authorship in the Days of Johnson (1927), pp. 156-58.

16. Hervey to Henry Fox, December 2, 1735, in Lord Hervey and His Friends, ed. Earl of Ilchester (1950), p. 242.

17. Sale Catalogue, No. 104. 


\section{Background of Thomson's Liberty}

18. Sherburn Festschrift, pp. 221-22.

19. Craftsman, repr. 1731, VII, 51, 54. No. 222, October $2,1730$.

20. John, Lord Hervey, Ancient and Modern Liberty Stated and Compared (1734), p. 51.

21. Sherburn Festschrift, p. 227; The Social and Political Ideas of Some English Thinkers of the Augustan Age, ed. F. J. C. Hearnshaw (1928), pp. 235-36.

22. For pointed allusions to Edward and Henry in Opposition verse, cf. Pope, Epistle to Augustus, 1l. 7-8; Johnson, London, ll. 99$100,117-20$.

23. Repr. 1731, VII, 117-18, dated November 21, 1730; original issue, October 17, 1730.

24. Thomson to Cranstoun, August 7, 1735: "The Book on the Sacrament is writ by Hoadley Bishop of Winchester. The Bigots roar against it" (transcript in National Library of Scotland). It may be noted that Hervey, an important supporter of the Government, disapproved of this book, though he was a friend of Hoadly's (Hervey to Horatio Walpole, September 9/20, 1735, in Lord Hervey and His Friends, p. 227).

25. Keith Feiling, The Second Tory Party 1714-1832 (1938), p. 35.

26. For the policy of the Old Whig, see also W. T. Laprade, Public Opinion and Politics in Eighteenth Century England (New York, 1936), chap. xii.

27. Daily Advertiser, January 14, 1735-36; London Evening-Post, January 13-15, 1736.

28. MP, XXV (1928), 456.

29. Craftsman, No. 476, August 16, 1735, repr. in part in Gentleman's Magazine, V (1735), 475-76, dated August 23. London Magazine, IV (1735), 433, also prints this number in part, but omits the long passages on Thomson's Liberty. These passages are also omitted from the collected edition of the Craftsman.

30. Gentleman's Magazine, VI (1736), 743. Another portrait of Thomson by Slaughter, now in the Art Gallery, Leicester, is reproduced in Douglas Grant, James Thomson (1951), opposite p. 120.

31. Thomson to Solomon Mendes [Mendez], July 21, 1737, in British Magazine and Review, I, (1782), 175.

31a. Samuel Boyse, Translations and Poems, Written on Several Occasions (1738), p. 251.

32. Imitation III in A Pipe of Tobacco (1736), previously published in the London Evening-Post, November 29-December 2, 1735, and in the Dublin Evening-Post, December 6-9. Most of the echoes of Liberty are noted in H. F. B. Brett-Smith's edition (Oxford, 1923), pp. 16-19. According to Dr. Armstrong, as reported in Malone's edition of Spence's Anecdotes (1820), p. 157 n., Thomson resented the parody, and "published a warm copy 


\section{Notes}

of verses against Mr. Browne, in one of the magazines or newspapers," containing the couplet:

Dost thou confound the poets in thy ire,

Thou man of mighty smoke, but little fire?

Malone's Spence is probably the source of later statements that Thomson wrote a reply to Browne (Bolton Corney's notes, repr. The Seasons [New York, n.d.], p. 325, and in many other editions; Morel, p. 112, following Chambers's Cyclopaedia of English Literature). The couplet quoted occurs in a somewhat different form in a set of verses in Gentleman's Magazine, VI (1736), 743, called “The Smoaker Smoak'd." The attribution to Thomson has not hitherto been made, as far as I know.

33. Hill to Thomson, February 17, 1735, in Works (1753), I, 222.

34. Hill to Thomson, January 17, 1735, ibid., p. 211.

35. "An Account of the Life and Writings of Mr. James Thomson," in Thomson, Works (1762), I, x.

36. Lives of the Most Eminent English Poets (1783), IV, 254.

37. Mrs. Catherine Macaulay, History of England (1763-65), I, xix.

38. Lives of the Most Eminent English Poets (1783), IV, 471.

39. Ibid., p. 464.

40. Memoirs of the Court of Augustus (2nd edition, 1760), I, 96, 99100, 107, 111, 213.

41. Literary Magazine, I (1756), repr. Works (1825), VI, 9-16.

42. History of England (1771), IV, 261.

43. Earl of Buchan, Essays on the Lives and Writings of Fletcher of Saltoun and the Poet Thomson (1792), pp. 214-17, 259.

44. History of Philip Waldegrave (1793), II, 166-67.

45. Margaret Ruth Lowery, Windows of the Morning (New Haven, 1940), pp. 140-48.

46. Quoted in Library of Literary Criticism, ed. C. W. Moulton, III, 263.

47. An elaborate analysis of the relation of Collins's Ode to Liberty to Thomson's Liberty is made by E. G. Ainsworth, Jr., Poor Collins (Ithaca, 1937), pp. 193-97. Not all of his parallels are convincing, but the indebtedness of Collins is clearly established.

48. Samuel Kliger, "The 'Goths' in England," MP, XLIII (1945), 112, 115-16; "Whig Aesthetics: A Phase of Eighteenth-Century Taste,” ELH, XVI (1949), 135-50. 



\section{INDEX}

Addison, Joseph, Cato, 7-8, 18; Letter from Italy, 16; Remarks on Italy, chap. iii passim; Spectator, 16; Tatler, 17

Agis, 49

Aglionby, William, Painting Illusstrated, 61,112

Agriculture, exaltation of, 55

Ainsworth, E. G., Jr., 117

Alps, 17, 71-72

Amelot de la Houssaye, 38

Anio, 29, 30-31

Antalcidas, Peace of, 48

Apelles, 65

Aristides, 4, 5, 49

Areopagus, 45

Armstrong, John, 91, 113, 116

Artaxerxes, 47-48

Athens, 45-46, 48-49

Augustan Age, 14

Bacon, Sir Francis, 5

Baia, 30, 32, 33, 34

Barozzi, Giacomo, 60

Barrow, Isaac, 5

Bartholin, Thomas, 81, 114

Bateson, F. J., 87

Beck, Thor J., 78

Benevolist ethics, 4, 107

Bieber, Margarete, 112

Blackwell, Thomas, Enquiry into the Life and Writings of Homer, 75; Memoirs of the Court of Augustus, 102

Blake, William, 103

Blomberg, Johann von, 77-78

Bolingbroke, Henry St. John, Viscount, 18, 87, 92, 94

"Bolognese School" in painting, 6871

Book of Drawing, 61

Boyle, Robert, 5

Boyse, Samuel, lines to Thomson, 10, 99-100

Brown, John, Athelstan, 114

Browne, Isaac Hawkins, Pipe of Tobacco, 100, 116-17
Brutus, Marcus Junius, 5, 53, 75

Buchan, David Steuart Erskine, Earl of, 102

Budgell, Eustace, 115

Burnet, Gilbert, Travels, 26, 34-36, 38-40

Burnet, Thomas, 109

Byron, Lord, 41

Caesar, Julius, 57-58

Capua, 32

Caroline, Queen, 88, 89, 96

Carracci, Annibale, 68, 70, 71

Cassius, Gaius, 5

Cato, Marcus Porcius, 4, 5, 7-8, 75

Centlivre, Susannah, 19

Charles II, 15, 18

Chase, Isabel Urban, 113

Child, Francis James, 103

Cicero, Marcus Tullius, 29, 45, 50

Cimon, 4, 49

Cincinnatus, Lucius Quintius, 5, 52

Climate, correlated with morals and politics, 47

Collins, William, 41, 44, 104, 117

Common Sense, 91

Conon, 48

Constantine's Arch, 62

Contempt of death among northern peoples, 79-82, 114

Corneille, Pierre, 59

Courthope, W. J:, 11

Craftsman, 87, 91, 92-94; on Liberty, 97-98

Crane, Ronald S., 111

Daily Advertiser, 91

Daily Gazetteer, 94

Daily Journal, 115

Davis, Rose Mary, 108

Dennis, John, Iphigenia, 18

Descriptive-didactic poem, 2

Diodorus Siculus, 43

Dobrée, Bonamy, 11

Dodington, George Bubb, 10, 20-23, $88,89-90,96$

D'Oria, Andrea, 36 


\section{Index}

Drake, Sir Francis, 5

Draper, John W., 111

Druids, 81-82

Dryden, John, 33, 59; translation of Dufresnoy, 61, 67, 70-71; "To Sir Godfrey Kneller," 69-70

Du Bos, Jean Baptiste, Réflexions critiques, 60, 61, 62

Dufresnoy, Charles Alphonse, Art of Painting, 61, 67, 70-71

Dyer, John, Ruins of Rome, 27

Egmont, John Perceval, Earl of, 115

Egypt, 42-44

Elsum, John, Epigrams, 72-73

English kings, political estimates of, 93-94

Epaminondas, 4

Félibien, André, Entretiens, 61, 62$63,66,67,70,72$

Farley, Frank E., 79, 82, 114

Feiling, Keith, 116

Fine arts, Thomson's attitude toward, 22-23; chap. v. passim; fostered by liberty, 13-14, 64; see also Painting, Sculpture

Fink, Zera S., 74, 109, 110

Flaminius, Titus Quinctius, 53

Florence, 35

"Florentine School" in painting, 6871

Florus, Lucius, 32, 33

Formiae, 31

France, English attitude toward, 1415, 20; Thomson's attitude toward, 22,64

Frederick, Prince of Wales, 6, 88-90, 91, 95-96

Geneva, 38

Genoa, 35-36

George II, 93, 96

Gibson, Edmund, Bishop of London, 90

Gillot, Hubert, 112

Goldsmith, Oliver, 40, 102, 110, 111

"Gothic," various connotations of the term, 19, 77-78, 104
Grand Tour, chaps. ii and iii passim

Grant, Douglas, 106, 107, 116

Gray, Thomas, 41, 44, 101-02

Greece, idealization of, 4-5, 18, 44$46,59-60$; political decline of, $47-$ 49; Romans restore liberty to, 5354; see also Athens, Heroism, Liberty, Painting, Sculpture, Sparta

Grotius, Hugo, 83

Hamilton, Horace E., 109

Hampden, John, 5

Harris, John, Travels, 27, 109

Havard, William, 111

Havens, Raymond D., 110

Hawley, William, 91

Heroism, in classical antiquity, 4-5, 48-49, 52; in English history, 5, 93-94; in primitive life, 75-76; Temple's conception of, 80

Hertford, Frances, Countess of, 2, 88, 89-90; letter from Thomson to, $23-25,95$

Hervey, John, Lord, 92, 93, 115, 116

Hill, Aaron, letters from Thomson to, 4; estimate of Liberty, 10001

Hoadly, Benjamin, Bishop of Winchester, Account of the Sacrament, 94, 116

Höltzle, Erwin, 113

Horace, 29, 32, 52

Hotoman, François, Franco-Gallia, 86

Hughes, Helen Sard, 24

Hutcheson, Francis, 107

Italy, English attitude toward, 16, 20; Thomson's attitude toward, 24-25, chap. iii passim; see also Painting, Rome, Sculpture

Jail Committee, 6, 90

Johnson, Samuel, 23; his opinion of Liberty, 101-03; London, 116

Jordanes, 77

Junius, Franz, De Pictura Veterum, 61

Juvenal, 33 
Kirk, Clara Marburg, 80

Kliger, Samuel, 74, 79, 104, 113

Lamotte, Charles, Essay upon Poetry and Painting, 61

Laocoon, 64

Laprade, W. T., 116

Larrabee, Stephen A., 63

Lassels, Richard, Voyage of Italy, 26-27, 33, 36

Lee, Rensselaer W., 112

Le Brun, Charles, 60

Liberty, associated with ethical standards, 4, 6, 12-13, 87; opposed to luxury, 7, 86; effect on national culture, 13-16; primitive or natural, $41,74-75,79$; civil or constitutional 12-13, 79, 83-85, 92-93; establishment in Greece, 44-46; decline in Greece, 47-49; identified with republican virtue in Rome, 7-9, 52-55; decline in Rome, 54-58; progress of, 3,35 , $41-42,50$, retreat of, $7,37,75-76$, 79,82 ; characteristic of northern peoples, 19-20, chap. vi passim; connection between classical and northern traditions of, 74-75; among ancient Britons, 82; claimed as typically English, 5-6, $13-14,18,22,83-85,92-93$; used as a theme in political controversy, chap. vii passim; transformation of landscape by, 16, 35-36, 38-39; see also Tyranny

Linck, Orville F., 107, 115

Livy, 53

Locke, John, 5

"Lombard School" in painting, 6871

Longinus, 13

Lorraine, Claude, 71

Loss of Liberty, or Fall of Rome, see Ralph, James

Louis XIV, 14,64

Lowery, Margaret, 103

Lucan, $75,80-81$

Licca, 35

Lucrine Lake, 30, 34
Luxury, opposed to liberty, 7, 86

Lycurgus, 4, 44-45

Lyttelton, George, Lord, 43, 91; continental travels, 20; Letters from a Persian in England, 101

Macaulay, Catherine, 101

Macaulay, G. C., 23

Magna Graecia, 51

Mallet, David, 92

Manwaring, Elizabeth Wheeler, 71

Marotti (Marotta), Carlo, 71

Marshall, Roderick, 110

Martial, 32

Maurice, Thomas, Netherby, 114

Mendez, Solomon, letter from Thomson to, 99

Michael Angelo, 64, 68

Milton, John, 5; Paradise Regained, 27; Paradise Lost, 113

Misson, François, New Voyage to Italy, 26, 27, 29, 34

Mola, 31

Molesworth, Robert, Viscount, Account of Denmark, 19-20, 38, 77, 83-84, 86

Monte Nuovo, 34

Montfaucon, Bernard de, Travels, 31,34

Moore, Cecil A., 11

More, Sir Thomas, 5

Murdoch, Patrick, 101

Naples, 29, 31, 32, 39-40

Newton, Sir Isaac, 5

Numa, 4, 52

Old Whig, 94, 110

Onslow, Arthur, 6, 88

Opposition to Walpole, ideology of, chap. vii passim

Ovid, 51

Painting, ranking of genres, 11 ; French neo-classical theory of, 59-61, 67-68; relation to sculpture, 62-66; relation to poetry, 67; in ancient Greece, 65; Italian schools, 68-73 
Palladio, Andrea, 61

Papal States, 39-40

Paterson, William, 91, 113; Arminius, 76

Peacock, Thomas Love, 86

Pelopidas, 4

Persia, 44, 47-48

Philopoemen, 49

Phocion, 49-50

Phoenicia, 44

Piles, Roger de, Abrégé de la vie des peintres, 60, 69; Conversations, 66 ; Cours de peinture, 60; on $\mathrm{Du}$ fresnoy, 61, 70-71

Pisa, 35

Pliny, 43

Plutarch, 4, 44-49, 53-56

Polite Correspondence, 114

Polybius, 16, 45

Pompey, 57-58

Pope, Alexander, 87; Essay on Criticism, 14,' 59; Epistle to Augustus, 15, 116; Essay on Man, 59

Poussin, Nicolas, 59, 62, 64, 66, 71-72

Praeneste, 30-31

Primitivism, 52

Prints in Thomson's collection, 71

Progress as an organizing concept in Thomson's poetry, 2-3

Protogenes, 65

Puffendorf, Samuel, 83

Pythagoras, 50-51

Quintilian, 13

Raleigh, Sir Walter, 5

Ralph, James, 5, 76

Raphael, 68, 71

Rapin-Thoyras, Paul de, History of England, 58, 81, 83-85, 86, 92, 93

Raven-banner, 82-83, 114

Ray, John, Observations made of the Low Countries, etc., 26-27, 37

Regulus, Marcus Atilius, 52, 111

Rehm, Walter, 111

Revolution of 1688, 13-14, 87

Richardson, Jonathan, Account of the Statues, etc., 62, 73; Essays on Painting, 61, 70; Two Discourses, 61

Rollin, Charles, Histoire ancienne, 42-51; Histoire romaine, 42; Belles lettres, 54

"Roman School" in painting, 68-71

Rome, as a model of political virtue, 8, 18, 52-55, 98, 102; restores Greek liberty, 53-54; conquests and imperial power of, 7-9, 27, 53; corruption and decline of, 15-16, 56-58; overthrown by barbarians, 75-78; ruins of, $5,24,75$; see also Heroism, Italy, Liberty

Rosa, Salvator, 71-73

Rowe, Nicholas, 81, 113

Rubens, 66

Rundle, Rev. Thomas, 1, 2, 90, 94, 113

Russell, William, Lord, 5

Sale, William M., Jr., 114, 115

Sammes, Aylett, 81

Sandys, George, Travels, 34

Sannazaro, Jacopo, 37, 110

Savage, Richard, 91, 99

Scandinavian origins of liberty, chap. vi passim

Scheffer, Johannes, 76

Scipio, Publius Cornelius, 4

Sculpture, 24, 62-67

Shaftesbury, Anthony Ashley Cooper, Earl of, 5; his doctrine of liberty, 12-13; Characteristicks, 12-13, 46

Shakespeare, William, 5

Shelley, Percy Bysshe, 41

Sidney, Sir Philip, 5

Siena, 35

Silius Italicus, 30

Slaughter, Stephen, 113; his portraits of Thomson, 98, 116

Socrates, 4, 45, 46

Solon, 4, 45-46

Sparta, 44-45, 47-48

Spence, Joseph, 107, 116

Statues, antique, described by Thomson, 63-64

Sulla, 56-57

Switzerland, as land of liberty, 17, 38; see also Alps 


\section{Index}

Tacitus, Cornelius, 13

Talbot, Charles, Baron, 1, 90-91

Talbot, Charles Richard, 1, 22

Talbot, William, 90

Temple, Sir William, 77, 79-80, 8384

Test Act, attempted repeal of, 94

Thomson, James, books in his library, $28,42,60-61,69,73,77$, $81,92,108,111,112,114,115$; letters: to Dodington, 1, 20-23; to Lady Hertford, 23-25, 95; to Aaron Hill, 4; to Solomon Mendez, 99; relations with Opposition, 6-7, 88-91; tour on the Continent, 1-2, 21-25, 107; works: dedications of, 88, 91; Agamemnon, 91; Alfred, 83; Britannia, 6, 11, 25, $88-89,95,115$; Castle of Indolence, 1, 9-10, 72, 73; Coriolanus, 51; Edward and Eleonora, 91; Liberty, writing and publication of, $2,25,106$; as a progress poem, 2-4; as epic and heroic, 9-11; political intentions and connections, 11, 88, 92-98; critical estimates of, 99-103; as a characteristic eighteenth century synthesis, 10305; and passim; Poem Sacred to the Memory of Sir Isaac Newton, 5; Poem to the Memory of Lord Talbot, 90-91; Seasons, 1, 2-4, 10 $11,21-22,25,26,44,103$; Autumn, 6; Spring, 51; Summer, 5-6, 7; Winter, 4-5, 6, 48, 52, 77; Sophonisba, 7-9, 10, 32, 89; Tancred and Sigismunda, 91

Tibur, 29, 30-31

Tillotson, John, 5

Timoleon, 4, 21, 48

Titian, 66, 72

Toynbee, Arnold, 75
Tracy, John, Periander, 114

Trenchard, John, Cato's Letters, 87

Trevelyan, Sir George M., 80

Turnbull, George, 102; Treatise on Ancient Painting, 61, 63, 73, 113

Tusculum, 29, 31

Tyranny, connected with luxury, 7, 86; associated with natural catastrophe, 31, 34-40; in Egypt, $42-44$

Venice, 37-38, 109-10

"Venetian School" in painting, 6871

Vertot, René Aubert de, 54-58

"Vignola," see Barozzi

Virgil, 29; Eclogues, 9; Georgics, 9, 16; Aeneid, 16

Voltaire, 22

Vox Populi, Vox Dei, 86

Walpole, Sir Robert, 6, 86-98, 101

Walsingham, Sir Francis, 5

Wells, John Edwin, 88, 108

West, Gilbert, 92, 98

Wharton, Philip, Duke of, 87

Whig panegyric, $11,17-18,75,89$, 98

Williams, John, 60

Williams, Ralph M., 109

Wilmington, Sir Spencer Compton, later Earl of, 88

Wimsatt, W. K., Jr., 111

Woodbridge, Homer, 80

Wotton, William, 13

Wright, Austin, 107

Wright, Edward, Some Observations Made in Travelling, etc., 28-29, $32,33,62$

Zeuxis, 65 
